Western Michigan University

T E A M S

Medieval Institute Publications/Arc Humanities Press

TEAMS Commentary Series

Medieval Institute Publications

4-12-2018

\title{
Rabbi Eliezer of Beaugency, Commentaries on Amos and Jonah (With Selections from Isaiah and Ezekiel)
}

\author{
Robert A. Harris \\ Jewish Theological Seminary, robbieharris1@mac.com
}

Follow this and additional works at: https://scholarworks.wmich.edu/mip_teamscs

Part of the Biblical Studies Commons, History of Religion Commons, Jewish Studies Commons, Language Interpretation and Translation Commons, and the Medieval Studies Commons

\section{Recommended Citation}

Harris, Robert A., "Rabbi Eliezer of Beaugency, Commentaries on Amos and Jonah (With Selections from Isaiah and Ezekiel)" (2018). TEAMS Commentary Series. 1.

https://scholarworks.wmich.edu/mip_teamscs/1

This Edition and/or Translation is brought to you for free and open access by the Medieval Institute Publications at ScholarWorks at WMU. It has been accepted for inclusion in TEAMS Commentary Series by an authorized administrator of ScholarWorks at WMU. For more information, please contact wmuscholarworks@wmich.edu.

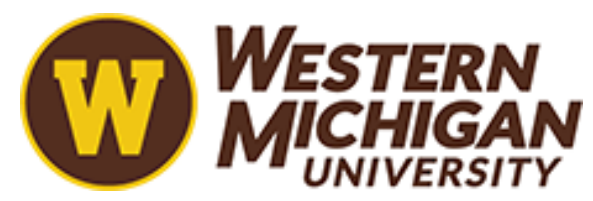




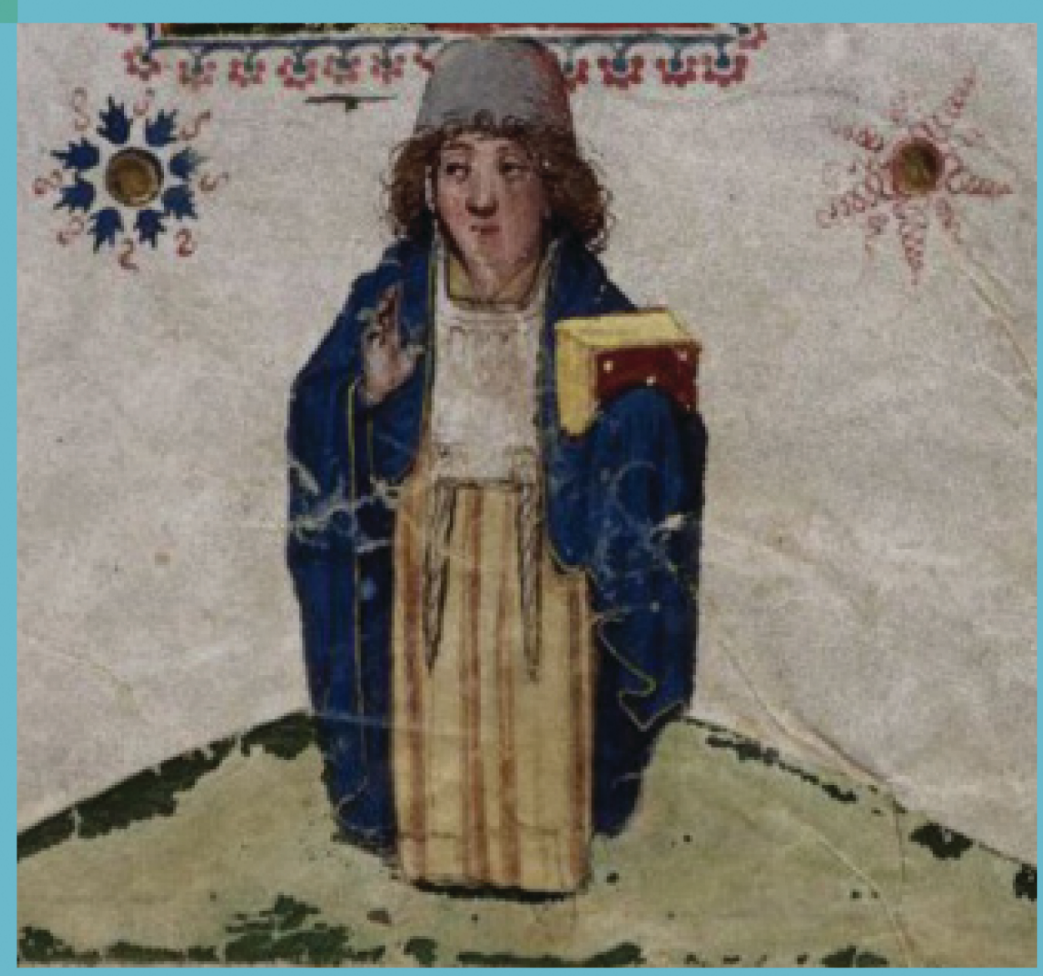

\section{RABBI ELIEZER OF BEAUGENCY COMMENTARIES ON AMOS AND JONAH}

Introduction, translation, and commentary by Robert A. Harris

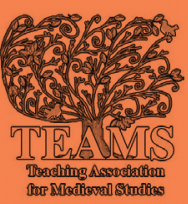




$$
\begin{gathered}
\text { Rabbi Eliezer of Beaugency } \\
\text { Commentaries on Amos and Jonah } \\
\text { (with selections from Isaiah and Ezekiel) }
\end{gathered}
$$




\title{
TEAMS
}

\section{COMMENTARY SERIES}

\author{
General Editor \\ E. Ann Matter, University of Pennsylvania
}

\author{
Advisory Board \\ John C. Cavadini, University of Notre Dame \\ Robert A. Harris, Jewish Theological Seminary \\ Patricia Hollahan, Western Michigan University \\ James J. O’Donnell, Georgetown University \\ Lesley J. Smith, Oxford University \\ Grover A. Zinn, Oberlin College
}

A list of the books in the series appears at the end of this book.

The Commentary Series is designed for classroom use. Its goal is to make available to teachers and students useful examples of the vast tradition of medieval commentary on sacred Scripture. The series will include English translations of works written in a number of medieval languages and from various centuries and religious traditions. The series focuses on treatises which have relevance to many fields of Medieval Studies, including theories of allegory and literature, history of art, music and spirituality, and political thought. Notes are meant to provide sources and to gloss difficult passages rather than to give exhaustive scholarly commentary on the treatise. The editions include short introductions which set the context and suggest the importance of each work.

\author{
Medieval Institute Publications is a program of \\ The Medieval Institute, College of Arts and Sciences
}




\title{
Rabbi Eliezer of Beaugency Commentaries on Amos and Jonah (with selections from Isaiah and Ezekiel)
}

\author{
by \\ Robert A. Harris
}

TEAMS

MEDIEVAL INSTITUTE PUBLICATIONS

Western Michigan University

Kalamazoo 
Copyright (C) 2018 by the Board of Trustees of Western Michigan University

\author{
Library of Congress Cataloging-in-Publication Data \\ are available from the Library of Congress.
}

ISBN hardbound: 9781580442732

ISBN paperbound: 9781580443036

eISBN: 9781580442749

All rights reserved. Without limiting the rights under copyright reserved above, no part of this book may be reproduced, stored in, or introduced into a retrieval system, or transmitted, in any form, or by any means (electronic, mechanical, photocopying, recording or otherwise) without the written permission of both the copyright owner and the author of the book.

Every effort has been made to obtain permission to use all copyrighted illustrations reproduced in this book. Nonetheless, whosoever believes to have rights to this material is advised to contact the publisher. 


\section{Contents}

Acknowledgments vii

Introduction $\quad 1$

R. Eliezer of Beaugency 3

The Commentary of Rabbi Eliezer of Beaugency on Amos 15

The Commentary of Rabbi Eliezer of Beaugency on Jonah 65

The Commentary of Rabbi Eliezer of Beaugency

on Isaiah (Selections)

Eliezer's Introduction to His Commentary on Isaiah 79

Discursive Analysis $\quad 85$

$\begin{array}{ll}\text { Compositional Technique } & 91\end{array}$

The Commentary of Rabbi Eliezer of Beaugency

on Ezekiel (Selections)

Eliezer's Introduction to His Commentary on Ezekiel 95

$\begin{array}{ll}\text { Bibliography } & 109\end{array}$

$\begin{array}{ll}\text { Index } & 115\end{array}$ 



\section{Acknowledgments}

THIS BOOK HAS BEEN so long in the writing that I can barely remember all of the contributions colleagues have suggested over the years. First among them, I would like to extoll the patience exhibited by the general editor of the TEAMS Commentary Series, Professor E. Ann Matter. We agreed that I would contribute this volume to the series many years ago, when we were both very much younger! I am delighted to see it published here, at long last.

Many colleagues read portions of this work over the years, or otherwise discussed the project with me. I am grateful to Alan Cooper, Edward L. Greenstein, Sara Japhet, Eva De Visscher, and Frans Van Liere.

I would like also to thank Tyler Cloherty, acquisitions editor, Theresa M. Whitaker, managing editor, and Martine Maguire-Weltecke, typesetter at Medieval Institute Publications for all of their help in bringing this volume to press.

I presented a paper on the subject of Eliezer's commentary on Jonah at a Medieval Congress meeting in Kalamazoo in May of 1998, and on Eliezer's commentary on Amos at a Society of Biblical Literature convention in November, 2004. I wish to thank everyone present on those occasions who raised critical objections and suggestions that I have incorporated herein.

For the introduction to this volume, I have incorporated material that I included in an article I wrote for the Stephen Geller festschrift; see Robert A. Harris, "Contextual Reading: Rabbi Eliezer of Beaugency's Commentary on Jonah," in Bringing the Hidden to Light: Studies in Honor of Stephen A. Geller (Diane Sharon and Kathryn Kravitz, ed. Winona Lake, IN: The Jewish Theological Seminary, in collaboration with Eisenbrauns, 2007), 79-101. I am grateful to the publisher for granting me the permission to use this here.

As always, my wife, Nellie, has been a source of support during the writing of this book. I also have always enjoyed the encouragement of my 
daughters-Merav, and son-in-law Jack Hasler; and Naamah, and son-inlaw Koby Imir — and, as well, my delightful grandchildren, Erez, Sarina, and Rosie! For the love of my family, I am grateful beyond words.

Lastly, I would like to dedicate this volume to my rav and mentor, Rabbi Joel Roth. While he is a renowned Talmudist and master of Jewish Law, Rabbi Roth is also exemplary in his devotion to and expertise in Biblical Hebrew grammar. But more than that, he has been, since I entered the Jewish Theological Seminary as an undergraduate in 1974, a second father to me, and I am grateful to him as only a son can be to a father. The Mishnah observes (Baba Metziah 2:11) that one's father brings a son into this world, whereas one's rabbi, from whom he has learned wisdom, brings him into the life of the World to Come. That is therefore a gift for which this volume's dedication is only a most modest acknowledgment. Nonetheless, let this introduction to the commentaries of Rabbi Eliezer of Beaugency serve as a kind of extended thank you note. 


\section{Introduction}

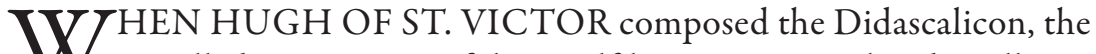
so-called Renaissance of the Twelfth Century was already well into its bloom. The flowering of biblical exegesis in Europe was one of the hallmarks of this Renaissance. Represented by such figures as Hugh himself among Christians, and Rabbi Samuel ben Meir (Rashbam) among Jews, this study increasingly took on the character of a contextual exegesis of biblical literature. While contextual exegesis, which we may associate with that approach generally called ad litteram among Christians and peshat among Jews, did not necessarily exclude the traditional teachings of the rabbis of the talmudic period and the fathers of the church, it nonetheless did not particularly emphasize them either. Rather, it sought to interpret sacred Scripture by allowing it to speak in its own voice. Hugh set forth the role of the interpreter of biblical texts through his definition of the process of exposition:

The exposition of a text takes place at three levels: the letter (litteram), the sense (sensum), and the meaning (sententiam). The letter is the suitable arrangement of words, which we also call grammatical constuction. The sense is the simple and clear signification that the letter displays on the surface. The meaning is the deeper understanding that is discovered only through exposition and interpretation. The proper order of inquiry among these is first the letter, then the sense, and finally the meaning. When this has been done, the exposition of a text is complete. ${ }^{1}$

The distinction made by Hugh between "sense" and "meaning" seems to be echoed in the occasional appeal of twelfth century rabbinic commentaries not merely to a peshat reading, but to the עומק פשוטו של מקרא, omeq peshuto

1 Translation taken from Franklin T. Harkins and Frans van Liere, Interpretations of Scripture: Theory (Turnhout: Brepols, 2012), 124-25. 
shel miqra, "the depth of a contextual reading of Scripture." Although the medieval rabbinic practitioners of peshat never precisely defined their methodology, one can hardly go wrong in at least beginning with the definition of this term offered by the late Sarah Kamin:

[Peshat is] an explanation (of a biblical passage) according to its language; its syntactic structure; its (immediate) literary context; its literary type, within a dynamic interaction among all of these components. Put differently, an interpretation according to peshat is an interpretation that considers all of the linguistic foundations in its literary composition, and assigns to each of them an understanding within a complete reading. ${ }^{3}$

One example of this, a celebrated excerpt from Rashbam's commentary on Genesis 37:2, bears a closer examination here. It encompasses not only a reference to deeper contextual reading, but also clearly draws the line between earlier rabbinic methodology, including that of his grandfather, R. Solomon ben Isaac (Rashi), and Rashbam's bold attempt to read Scripture with an exclusively contextual orientation:

Lovers of reason should understand it well that, as our rabbis tell us, no scriptural verse ever escapes the hold of its context [peshuto]. Although it is also true that the main aim of the Torah is to teach us laws, doctrines, and rules of conduct which are derived by hint or by the use in scriptural verses of superfluous words or by means of the thirty-two rules of Rabbi Eliezer ben Rabbi Yosi the Galilean or the thirteen rules of Rabbi Ishmael. In their piety the early scholars devoted all their time to the midrashic explanations, which contain, indeed, the main teachings of the Torah. But, as a result, they became unfamiliar with the deeper aspects of the text's contextual meaning...

2 See, e.g., the commentary of R. Samuel ben Meir (Rashbam) on Genesis 49:16, where he critiqued the interpretation of his grandfather, Rashi, with the words, "the one who would interpret [the verse in such a faulty way] does not understand the depth of the contextual interpretation at all!" An older translation of the Didascalicon rendered the distinction between sensum and sententiam as "the sense" and "inner meaning," which in a sense provides a more recognizable parallel to Rashbam's formula; see Jerome Taylor, The Didascalicon of Hugh of St. Victor (New York: Columbia University Press, 1961), 92.

${ }^{3}$ Sarah Kamin, Rashi's Exegetical Categorization in Respect to the Distinction Between Peshat and Derash [Hebrew] (Jerusalem: The Magnes Press, 1986), 14. The translation is my own. 
Our master, Rabbi Solomon, my mother's father [i.e., Rashi], who illumined the eyes of all those in exile, and who wrote commentaries on the Torah, Prophets and the Writings, also set himself the task of elucidating the contextual meaning of Scripture. And I, Samuel, son of his son-in-law Meir, may the memory of the righteous be for a blessing, argued with him [Rashi] (i.e., privately) and in his presence (i.e., in the school house). He admitted to me that if he had the time he would have written new commentaries in accordance with the fresh interpretations of the contextual meaning that are innovated daily....

Jewish and Christian biblical expositors in twelfth century northern France worked within the same cultural and intellectual milieu. Hugh's definition of contextual scholarship found its fullest expression, in his own school, in the writings of Andrew of St. Victor. The devotion to a purely contextual or peshat exegesis found its clearest exponents among Jews in Rashbam and his disciple, Rabbi Eliezer of Beaugency. It is the purpose of this introductory essay to examine the writings of this latter twelfth century rabbinic exegete of the Bible, and, especially, to introduce the reader to Eliezer's biblical commentaries.

\section{R. Eliezer of Beaugency ${ }^{4}$}

Although it seems clear that Eliezer commented on many, if not most, of the books in the biblical canon, only one manuscript, containing three exegetical works, is extant. This is Oxford, Bodleian Library, MS Opp. 625 (= Neubauer 1465) containing Eliezer's commentary on Isaiah, Ezekiel, and the Twelve so-called "Minor" Prophets. The commentaries in this manuscript were not identified until the nineteenth century; they were published at the end of the nineteenth century, and towards the beginning of the twentieth. ${ }^{5}$ Virtually the entire remainder of Eliezer's exegeti-

${ }^{4}$ This section is rooted in the observations I first made in my dissertation, "The Literary Hermeneutic of Rabbi Eliezer of Beaugency," dissertation, Jewish Theological Seminary, 1997.

${ }^{5}$ Eliezer's commentary on Isaiah was published first: John W. Nutt, Commentaries on the Latter Prophets By R. Eliezer of Beaugency: Isaiah [Hebrew, with English introduction] (London, Paris and Frankfurt: Joseph Baer and Co., 1879). The commentaries on Ezekiel and the Twelve were published by Samuel Poznanski, Commentary on Ezekiel and the Twelve Minor Prophets By Eliezer of Beaugency [Hebrew] (Warsaw: Mikize Nirdamim, 1913). Poznanski's lengthy introduction to his edition of Eliezer's commen- 
cal labors, including commentaries on the Pentateuch, Former Prophets, and the Five Scrolls, is presumed to be lost.

Regarding the biographical details of his life, we are faced with a paucity of information. Eliezer does not, like many other medieval exegetes, refer to his father's name, describe travels he undertook or contemporary events, or any role he may have played in his community; he only barely mentions the name of his teacher, Rabbi Samuel ben Meir (Rashbam). Although Avraham Grossman has deduced from the commentaries that Eliezer participated in the anti-Christian polemic of his generation, his argument rests on Eliezer's occasional polemical comments, and we cannot relate these to any particular disputation or discussion in which he may have taken part. ${ }^{6}$ Norman Golb has placed Eliezer in the Norman city of Rouen "in the early fifties of the twelfth century." However, even with these few additional details, the judgment of the Wissenschaft scholar, Samuel Poznanski, that "almost nothing is known (about Eliezer)" is unfortunately as true today as when he wrote at the turn of the century. ${ }^{8}$

Moreover, the name of his place of residence, "Beaugency" - transliterated in Hebrew as בלגנצי (blgntsy), when attached to Eliezer's name appears in manuscripts in such permutations as bagtsy, balgyytsy, bayytsy, and others. However, there is no doubt as to which town is being referred

tary on Ezekiel and the Twelve (the editio princeps) is a monograph in its own right, and remains the starting point for all studies of eleventh to twelfth century northern French rabbinic exegesis of the Bible. These commentaries have now been included in the critical edition of the rabbinic Bible; begun in 1992 (with the Joshua-Judges volume), this edition is not yet complete, although nearly twenty volumes have been published. Although I have consulted the lone manuscript, the relevant volumes for the present translation are: Menachem Cohen, ed., Mikraot Gedolot 'Haketer': A Revised and Augmented Scientific Edition of 'Mikraot Gedolot'Based on the Aleppo Codex and Early Medieval Mss: Isaiah (Ramat Gan: Bar Ilan University, 1996); Ezekiel was published in this series in 2000, and the Twelve in 2012.

6 See Avraham Grossman, "The School of Literal Exegesis in Northern France," in Hebrew Bible/old Testament: The History of Its Interpretation. Volume I: From the Beginnings to the Middle Ages (Until 1300). Part 2: The Middle Ages (Magne Saebo, ed. Gottingen: Vandenhoeck \& Ruprecht, 2000), 321-71 (363-66).

${ }^{7}$ Norman Golb, The Jews in Medieval Normandy: A Social and Intellectual History (Cambridge: Cambridge University Press, 1998), 319-24. To be sure, Golb wishes to locate virtually every known twelfth century northern French rabbi in Rouen, so some of his conclusions, at the very least, need to be taken with a healthy grain of salt.

${ }^{8}$ Samuel Poznanski (1913), cxxv. 
to. As Poznanski notes, the name of the Roman village Balgentiacum has undergone various permutations through the ages. Beaugency is located in northern France near Orleans, in the Loire river valley.

Regrettably, identifying Eliezer as one who hailed from Beaugency does not enhance our information about him. Next to nothing is known about the Jewish community of Beaugency during the period of Jewish settlement in northern France until the expulsion of 1306. Authoritative studies of the history of northern French Jewry during this period barely mention a Jewish community in Beaugency, and often the only indicator is considered to be the association of the name of the town with Eliezer's name. In fact, it may well prove to be true that there never was much of a Jewish community in Beaugency, and that, since "Eliezer" was a common Jewish name, he was known as "the Eliezer who was from Beaugency" to differentiate him from the others of that period who share the name. Thus we are left with no more than a sketchy portrait of Eliezer, the man of Beaugency.

Regarding Eliezer, the exegete of Beaugency, however, we are in a somewhat better situation. As a biblical commentator, Eliezer is virtually unparalleled in the medieval Jewish world in the degree to which he pays attention to the literary or rhetorical qualities of biblical compositional technique. While this observation is easily demonstrable when considering the entire range of Eliezer's extant corpus of exegesis (the commentaries on Isaiah, Ezekiel, and the Twelve Minor Prophets), in this book I have chosen to present Eliezer's commentaries on Amos and Jonah, complemented with a representive selection of his (understandably longer) commentaries on Isaiah and Ezekiel. In an effort to allow the reader to assay Eliezer's exegesis on an entire biblical book, I begin with his commentary on Amos, both for the brevity, and also for the importance, of this prophetic work. Moreover, as we shall see, in this commentary, Eliezer displays great acuity both with respect to prophetic rhetoric as well as to the book's compositional techniques, and so provides an excellent example of his exegetical approach and hermeneutic.

As stated above, the vast majority of Eliezer's oeuvre did not survive the exigencies (and ravages) of the Middle Ages; particularly, the loss of his commentaries on the Torah and Former Prophets has effectively denied readers a sustained opportunity to appraise Eliezer's method of interpreting legal and narrative texts (prophetic texts being primarily poetic in nature). Therefore I chose as well to translate his commentary on Jonah, the one predominantly narrative work contained in the surviv- 
ing corpus, which allows the reader to determine if Eliezer's hermeneutic changes when dealing with this prominent type of biblical discourse. ${ }^{9}$ Additionally, Eliezer's focus on the book's contextual exegesis enables him also to address issues of character analysis, and Jonah's had traditionally been in need of some aid..$^{10}$ For, according to the biblical narrative, not only does Jonah not obey God's original command to go prophesy to the Ninevites (1:2-3) he apparently becomes distressed when God revokes the decree of destruction (3:10-4:1). However, Eliezer claims that this is not the way the narrative should be understood. On the contrary, Eliezer makes the case that the reader is privy to information effectively denied to the narrative's central character. Unlike Jonah, the reader knows that the Ninevites do respond favorably to Jonah's prophetic word, and that they repent of their evil ways.

Finally, since Eliezer's most prominent surviving works are his interpretations of Isaiah and Ezekiel, the present translation affords readers a glimpse into these important commentaries. Eliezer wrote brief introductions to each of those books, and I have included both of these in this edition. While not complex compositions along the lines of those thirteenth century examples discussed by Alastair Minnis, ${ }^{11}$ Eliezer's introductions do provide a kind of early Jewish counterpoint to the prevailing Christian

9 An additional boon of translating Eliezer's commentary on Jonah is related to the publication, also in the TEAMS Commentary Series, of Deborah Everhart's translation of Haimo of Auxerre's Commentary on Jonah: Deborah Everhart, Commentary on the Book of Jonah: Haimo of Auxerre (Kalamazoo: Medieval Institute Publications; Western Michigan University, 1993). Haimo, of course, is a ninth century Christian exegete - thus living approximately three centuries earlier than Eliezer - who wrote according to a completely different poetics (Christian allegory). Nonetheless, despite their differences, it is useful to be able to present to the public (and in the same series) Christian and Jewish commentaries on the same text. To be sure, it is to be hoped that a wide selection of twelfth century Victorine and northern French rabbinic commentaries be studied in tandem and published in critical editions and translation, to enable even more fruitful comparative and contrastive studies. In addition to other volumes in the TEAMS Series, two impressive examples of this are: Frans Van Liere, Andrew of St. Victor: Commentary on Samuel and Kings: Introduction, Translation and Notes (Turnhout: Brepols, 2009); and a text I have already cited, Franklin T. Harkins and Frans van Liere, Interpretations of Scripture: Theory (Turnhout: Brepols, 2012).

${ }^{10}$ See Yvonne Sherwood, A Biblical Text and Its Afterlives: The Survival of Jonah in Western Culture (Cambridge: Cambridge University Press, 2000).

11 A. J. Minnis, Medieval Theory of Authorship: Scholastic Literary Attitudes in the Later Middle Ages (Philadelphia: University of Pennsylvania Press, 2010). 
trends. ${ }^{12}$ With respect to the excerpts from Eliezer's commentaries on Isaiah and Ezekiel, I have sought to include both examples that are representative of his exegetical methodology, as well as some whose content are of particular interest. In particular, as was the case with the commentaries on Amos and Jonah, the exemplary nature of Eliezer's commentaries on Isaiah and Ezekiel are not to be found in the realm of theology or religious practice; rather, Eliezer's concerns are, in the main, literary. That is, he is most interested in enabling his reader to understand the substance and essential meaning of the biblical passage under review. To draw a contrast, whereas Christian exegetes might endeavor at great length to tease out the apocalyptic ramifications of the four beasts in Ezekiel 1, or where Jewish and Christian exegetes alike might seek to fully explain the metaphorical implications of God's command to eat the scroll in Ezekiel 3, Eliezer is much more interested in clarifiying biblical texts whose basic meaning is unclear, or to otherwise concern himself with compositional and structural literary concerns that would typically stand outside the purview of other medieval exegetes. Moreover, this clarification often takes the form of paraphrase: it is not at all the case that Eliezer's commentary is composed on the basis of "text/incipit followed by commentary," but rather, particularly when he senses the text to be especially laconic and allusive, he composes a commentary that is essentially an expanded version of the Biblical text itself.

Although Eliezer's attention to rhetoric is extraordinary for a medieval Jewish exegete, it is clear he did not operate in a scholarly vacuum; several prominent exegetes preceded him whose work to some degree influenced his own. In fact, in considering the course of the northern French rabbinic peshat school of biblical exegesis, the so-called School of Rashi, Eliezer falls, along with R. Yosef Bekhor Shor (Joseph of Orleans) at the very end of that school's prominence. The commentaries of R. Solomon ben Isaac (Rashi) were, for all of the French commentators who followed him, including Eliezer, highly influential. Moreover, the exegesis and methodology of Rashi's grandson, Rashbam, made an especially important contribution to Eliezer's development as a biblical exegete. To a lesser extent, the commentaries of Rashi's younger contemporary, R. Yosef Kara,

${ }^{12}$ For a more extensive discussion, see Eric Lawee, "Introducing Scripture: The Accessus Ad Auctores in Hebrew Exegetical Literature From the Thirteenth Through the Fifteenth Centuries," in With Reverence for the Word: Medieval Scriptural Exegesis in Judaism, Christianity and Islam (J.D. McAuliffe, B.D. Walfish, and J.W. Goering, eds., Oxford: Oxford University Press, 2003), 157-79. 
likewise influenced Eliezer. Finally, the traditions and literature (whether learned in traditional master-to-student instruction or from the reading of literary texts ${ }^{13}$ ) that were commonly available to northern French rabbis of the time was likewise available to Eliezer; Targum, Talmud, midrash, and other rabbinic literature, while not finding expression to a high degree in his commentaries, are nevertheless referred to occasionally, and presumably formed the basis for Eliezer's own rabbinic education. ${ }^{14}$

In the footnotes to the present translation, I have endeavored to cite not only relevant contemporary bibliography and other types of information typically found in works of modern scholarship, but have sought also to incorporate a kind of "supercommentary" intended to demonstrate how to read the Bible through the vision of Eliezer's commentary. In my translation I tend towards a literal rendering, and have tried faithfully to represent the language of Eliezer's commentary, with a minimum of expansion. In general, I try not to "smooth" Eliezer's sometimes run-on sentences into better English. When I feel the need to express words or thoughts that Eliezer seems to presume but does not state, I employ words or phrases in parenthesis, trying to keep these to a bare minimum. A classic case in point, repeated throughout the present volume, involves the citations of biblical verses. First, rabbinic exegetes presume that their students know the Bible by heart. This is not an exaggeration but is demonstrated throughout the entirety of medieval rabbinic exegesis both of the Bible and of the Talmud: typically, a rabbinic exegete cites only a very few words from a biblical verse, expecting that his student or reader will be able to complete the verse in his own mind. Therefore, the reader should not expect to find that Eliezer cites entire verses, either as the incipit or in the course of his commentary; where I felt the need to reference more of the biblical text, for the sake of the contemporary reader, I placed additional words in parenthesis. Likewise, the reader should not expect to find the Bible consistently translated according to one or another modern translation (e.g., RSV or NJPS); rather, I have attempted to present an English translation of the Bible that most faithfully reflects the passage according to Eliezer's own interpretation.

13 See below.

${ }^{14}$ For a concise presentation of the history of northern French rabbinic exegesis of the Bible, see Avraham Grossman, "The School of Literal Exegesis in Northern France" (2000); and Robert A. Harris, "Jewish Biblical Exegesis in the Middle Ages: From Its Beginnings Through the Twelfth Century," in The New Cambridge History of the Bible (Richard Marsden and Ann Matter, eds., Cambridge University Press, 2012), 596-615. 
Like most rabbinic exegetes of the Northern French School, Eliezer occasionally employs Old French translations for difficult Biblical Hebrew words or phrases. In addition to Poznanski's notes (ad. loc.), I have relied for my translations upon the following dictionaries and studies:

Banitt, Menahem, ed. Le Glossare De Bale: Introduction, Corpus Glossariorum Biblicorum Hebraico-Gallicorum Medii Aevi, Tomus Primus. Jerusalem: The Israel Academy of Science and Humanities, 1972.

Banitt, Menahem. Le Glossare De Bale: Texte, Corpus Glossariorum Biblicorum Hebraico-Gallicorum Medii Aevi, Tomus Primus. Jerusalem: The Israel Academy of Science and Humanities, 1972.

Banitt, Menahem. Le Glossaire De Leipzig: Texte. Vol. 1, Corpus Glossariorum Biblicorum Hebraico-Gallicorum Medii Aevi, Tomus Secundus. Jerusalem: The Israel Academy of Sciences and Humanities, 1995.

Fudeman, Kirsten A. “The Old French Glosses in Joseph Kara's Isaiah Commentary (Ms Lutzki 778)." Revue des études juives 165:1-2 (2006): 147-77.

Greimas, Algirdas Julien. Dictionnaire De L'ancien Français. Paris: Larousse, 1992.

Hindley, A., F. W. Langley, and B. J. Levy. Old French-English Dictionary. Cambridge: Cambridge University Press, 2000.

One final note: This translation presents a commentary that is both reflected by, as well as reflected in, the exegetical trends of the twelfth century Christian scholarly community with which it is contemporary. Two generations ago Beryl Smalley pointed to exegetical methodologies and contents that were common to both Christian and Jewish medieval biblical scholarship. Today we are able to state unequivocally that during the twelfth century northern French Renaissance, Jews and Christians began to approach the interpretation of the Bible in strikingly similar ways, even as the content of the commentaries continued to express the different orientations of their respective faith traditions. Moreover, I refer here neither merely to the "smoking guns" of direct polemical address, ${ }^{15}$ nor to the

15 In rabbinic circles, these would typically be introduced by the phrase תשובה למינים teshuva la-minim); literally, "a response to 
occasional, similar interpretations that have led any number of modern researchers to look for direct influence. ${ }^{16}$ Of much greater importance is the similarity in outlook that twelfth century rabbis and churchmen share when engaging in the process of explicating a biblical text: Readers familiar with medieval Christian biblical exegesis will recognize that Eliezer (like his northern French rabbinic forebearers) employs a hermeneutic that reflects the essential norms and practices of contemporary (especially Victorine) Christian glossators. This similarity is both of an intellectual as well as a technological nature. ${ }^{17}$ The latter is, perhaps, easier to understand: whereas Christian exegetes had long before adopted the ancient Greco-Roman tradition of glossing the works of classical and biblical authors (and whereas both Muslims and Jews in the Mediterranean world

the heretics." Throughout twelfth century rabbinic exegesis of the Bible, this phrase always and everywhere - refers to Jewish-Christian polemics. On the use of the term in medieval Jewish exegesis, see Michael Signer, "Consolation and Confrontation: Jewish and Christian Interpretation of the Prophetic Books," in Scripture and Pluralism: Reading the Bible in the Religiously Plural Worlds of the Middle Ages and Renaissance (Thomas J Heffernan and Thomas E Burman, eds. Leiden; Boston: Brill, 2005), 77-93 (91); Shaye J. D. Cohen, "Does Rashi's Torah Commentary Respond to Christianity? A Comparison of Rashi With Rashbam and Bekhor Shor," in The Idea of Biblical Interpretation: Essays in Honor of James L. Kugel (J. Kugel, H. Najman, and J. Newman, eds., Leiden; Boston: Brill, 2004), 449-72; and Ephraim Kanarfogel, "Trinitarian and Multiplicity Polemics in the Biblical Commentaries of Rashi, Rashbam and Bekhor Shor," Gesher 7 (1979): 15-37. There is extensive research on this subject in modern Israeli scholarship.

${ }^{16}$ See, e.g., Gilbert Dahan, "Les interpretations juives dans les commentaires du Pentateuque de Pierre le Chantre," in The Bible in the Medieval World: Essays in Memory of Beryl Smalley (Studies in Church History: Subsidia 4, Katherine Walsh and Diana Wood, eds., Oxford: Basil Blackwell, 1985), 131-56. A classic and extended examination of fourteenth century Christian exegesis (Nicholas de Lyra) that overlaps with prior Jewish interpretation (Rashi) is found in Herman Hailperin Rashi and the Christian Scholars (Pittsburgh: University of Pittsburgh Press, 1963). An additional striking example is found in Sarah Kamin and Avrom Saltman, Secundum Salomonem: A 13th Century Latin Commentary on the Song of Songs (Ramat Gan: Bar-Ilan University Press, 1989).

${ }^{17}$ I make this argument more fully in a recently written, though not yet published, article, entitled "From 'Religious Truth-Seeking' to Reading: The Twelfth Century Renaissance and the Emergence of Peshat and Ad Litteram as Methods of Accessing the Bible." It is to be published in the conference volume from The Melton Coalition Conference In Jerusalem: The Oral and the Textual in Jewish Tradition and Jewish Education (The Hebrew University of Jerusalem, December 28-30, 2014). 
had done so, likewise, albeit in Arabic), European Jews had not adopted the commentary genre until the late eleventh and early twelfth centuries. ${ }^{18}$ It is not often remarked how truly revolutionary the commentary form was to medieval European Jewry, and this leap in technology - writing literary, textual glosses, "on the page" and not in a separate work greatly contributed to the new type of contextual reading advocated by twelfth century rabbinic masters. ${ }^{19}$ But even beyond the technological changes, the common intellectual and ideological approach to reading among twelfth century Jewish and Christian masters is often overlooked: because the contents of rabbinic and Christian exegesis is so remarkably (and expectedly) different, it is easy to miss that both the 12th century rabbinic pashtanim, or "advocates of contextual biblical reading," and Christian scholars who practiced ad litteram methodologies, shared the goal of not necessarily overturning older traditional theologies, liturgies, and religious practices but of adding to them an essentially literary reading that expressed fidelity to what the ancient biblical text had meant in its own historical period.

Both Hugh of St. Victor and Rashbam, rough contemporaries and with whom we began this introduction, were pious scholars, steeped in the devotions of their respective faiths. And yet each sought to find a place at the table, as it were, for context as a key element to determine the meaning of a biblical passage - this not as a threat to religious faith or practice but as an enhancement of it.

Let us examine two brief examples. The first of these is an excerpt from Hugh's Didascalicon (Book Six, Chapter 10):

There are certain places in Sacred Scripture where, although the meaning of the words is clear, there nevertheless seems to be no

${ }^{18}$ In particular, Karaite Jews (living a few centuries earlier and residing in areas of Muslim political, linguistic, and cultural dominance) had adopted the commentary genre in their biblical exegesis, and this had an influence on contemporary Rabbanite circles. In particular, see Daniel Frank, Search Scripture Well: Karaite Exegetes and the Origins of the Jewish Bible Commentary in the Islamic East (Leiden; Boston: Brill, 2004). Virtually all of this exegesis, however, Karaite and Rabbanite alike, was composed in Arabic, and therefore could have only an indirect influence on northern European Jews who did not know that language.

${ }^{19}$ On the transition from oral to literary culture in medieval rabbinic culture, see Talya Fishman, Becoming the People of the Talmud: Oral Torah as Written Tradition in Medieval Jewish Cultures (Philadelphia: University of Pennsylvania Press, 2011). 
sense, either because of an unfamiliar mode of expression or because some detail of the text hinders the comprehension of the reader... perhaps you are unable to understand what the whole passage taken together signifies... Therefore, you think that the passage, whose literal meaning you cannot discern, must be understood in a strictly spiritual sense... See, you have interpreted the passage spiritually, but you do not understand what it might intend to say according to the letter. The Prophet, however, was also able to signify something with these words according to the letter. ${ }^{20}$

Again, observe that Hugh does not intend to negate the spiritual dimension of Sacred Scripture, but only wishes to advocate the contextual meaning that he thinks is all too often misunderstood. We had earlier discussed a similar passage from Rashbam's commentary; let us now turn to another, where he not only advocates on behalf of reading in context but boldly acknowledges that this reading may utterly contradict received and authoritative religious tradition about biblical law:

Let knowers of wisdom know and understand that I have not come to explain halakhot ${ }^{21}$ even though these are the essence of Torah, as I have explained in my Genesis commentary. For it is from the apparent superfluousness of Scripture that aggadot and halakhot are derived. ${ }^{22}$ Some of these can be found in the commentary of our Rabbi Solomon, my mother's father (i.e., Rashi), may the memory of the righteous be for a blessing. But I have come to explain the contextual meaning of Scripture. And I will explain the laws and halakhot according to realia (lit. "the way of the world"). And (I will do this) even though the halakhot are the essence (of Judaism), as the Rabbis taught (BT Sotah 16a): "halakha uproots Scripture."

Rashbam composes this passage as a kind of introduction to the legal portion of the Pentateuch (at Exodus 21:1), the very spot at which the Torah transitions from an essentially narrative document to a predominantly legal document. He thus chooses his ground carefully: at precisely the

${ }^{20}$ Harkins, and van Liere, Interpretations of Scripture: Theory (2012), 176.

${ }^{21}$ I.e., matters pertaining to Jewish Law, as this may either pertain or not pertain to specific biblical legal verses.

${ }^{22}$ Rashbam references here ancient and authoritative rabbinic narrative and legal traditions, respectively, that the Talmud and other rabbinic works call "Oral Torah." The rabbis considered these to be as much a part of Divine Revelation as the "Written Torah," i.e., the Bible. 
moment when a Jewish reader might think that reading according to the Bible's ancient context would be a threat to rabbinic legal traditions about the practice of Judaism, Rashbam states unequivocally that the Torah can sustain a multivocalic reading, both conveying its original and contextual meaning as well as eternal religious truth. ${ }^{23}$ One immediately can see how similar Hugh and Rashbam are in intellectual outlook, even as they themselves might have been astonished at this notion.

As a principal student of Rashbam, Eliezer of Beaugency boldly continued the exegetical program of his master. ${ }^{24}$ By analogy, Andrew of St. Victor did so likewise with respect to Hugh's prior teaching. ${ }^{25}$ Each of these two exegetes became the exemplars par excellence of Jewish and Christian contextual biblical exegesis in the mid-to-late-twelfth century. Having briefly introduced the reader to Rabbi Eliezer of Beaugency's exegetical methodology and set him within the context of 12th Century biblical exegesis, let us now turn to his commentaries, and read Scripture as he would have us read it.

${ }^{23}$ For a discussion of this distinction between literary context and "religious truth seeking" in twelfth century northern French rabbinic culture, see Robert A. Harris, "Concepts of Scripture in the School of Rashi," In Jewish Concepts of Scripture: A Comparative Introduction (Benjamin D. Sommer, ed., New York and London: New York University Press, 2012), 102-22.

${ }^{24}$ In fact, Eliezer was one of the few exegetes whose name has survived who consistently pursued Rashbam's program of contextual exegesis to the exclusion of rabbinic traditions. See Ephraim Kanarfogel, The Intellectual History and Rabbinic Culture of Medieval Ashkenaz (Detroit: Wayne State University Press, 2013), 118-26.

${ }^{25}$ See above, note 6. 



\section{The Commentary of Rabbi Eliezer of Beaugency on Amos ${ }^{1}$}

\section{Chapter One}

1:1: Among the herdsmen: ${ }^{2}$ As in and Mesha, King of Moab, was a herdsman, ${ }^{3}$ for he possessed cattle, for he was a great lover of cattle. So, too, Amos originally possessed cattle. ${ }^{4}$ And since it was the custom of shep-

1 Throughout this edition, I shall adhere to the following format: I shall present the incipit, any citation from the current verse, in bold face type; I will use italics to indicate any verse Eliezer cited from other biblical books or different contexts from the book he is explicating; and for Eliezer's own interpretations, I will use regular typeface. Like virtually all modern editions of the Bible, I employ here the anachronistic chapter and verse distinctions that Stephen Langton introduced in the Parisian Bibles, even though rabbis did not typically use these until after the invention of printing. Finally, my general practice with respect both to Eliezer's incipits as well as to the verses he cites in support of his interpretations is to translate the Bible through Eliezer's eyes. Thus, the translation does not necessarily follow the insights of contemporary scholarship. Of course, when I do rely on modern translations, I designate these through their well-known sigla, e.g., NJPS stands for Tanakh: A New Translation of the Holy Scriptures According to the Traditional Hebrew Text (Philadelphia: Jewish Publication Society, 1985).

${ }^{2}$ Heb. נקדים, noqdim, specifically referring to "sheep-breeders." See S. R. Driver, The Books of Joel and Amos (Cambridge: Cambridge University Press, 1907), 125; Shalom Paul, Amos. Hermeneia - A Critical and Historical Commentary on the Bible (Minneapolis: Fortress Press, 1991), 34-35; further citations from Paul's magisterial commentary will be noted by author, year, and page number only. See also the recent monograph by Richard C. Steiner, Stockmen from Tekoa, Sycomores from Sheba: A Study of Amos' Occupations (Catholic Biblical Quarterly Monograph Series 36. Washington DC: Catholic Biblical Association of America, 2003). A translation more specific to Eliezer's commentary might be "staff-handlers." Eliezer, as will immediately become evident, knows that the term occurs only once more in Scripture.

3 See 2 Kings 3:4.

${ }^{4}$ See Amos 7:14, although there the term Amos employs is בוקר, boqer, a unique term in Biblical Hebrew, apparently meaning "cattle-breeder." For a critical discussion of the term, see Paul (1991), 247-48. 
herds to peel sticks of wood, to cause the flock to give birth to spotted young, ${ }^{5}$ (the text) calls him a herdsman, on account of the staff. ${ }^{6}$ (Amos) prophesied ${ }^{7}$ about the earthquake, two years before it (happened), ${ }^{8}$ and thus did he say:

1:2: The LORD, from Zion, roars, and from Jerusalem - the site of His Sanctuary ${ }^{9}$ - does he give his voice, and the earth shook and quaked before him. ${ }^{10}$ It appears as though the quaking of this roaring happened in connection with the decree concerning the great and mighty nations like those he is about to enumerate: (the decree) was sealed, and the time had arrived for these nations to be struck.

The top of Carmel: its summit.

1:3: For three sins of Damascus: ${ }^{11}$ The nation soonest to be struck he mentions first. And even though Judah and Israel were struck before Tyre, Moab, Ammon and Edom, he leaves them for last, since he treats them at

5 נקודים נים, nequdim, ("spotted"), which both looks and sounds like the word נקדים ("sheep-breeders"); see note 2. The reference here is to Gen. 30:37-43, where Jacob arranges to increase his flock at Laban's expense, employing the method that Eliezer here describes.

${ }^{6}$ I.e., the staff a shepherd or herdsman holds.

${ }^{7}$ Eliezer paraphrases the text here, using Mishnaic Heb. נתנבא, nitnabeh, ("prophesy"), instead of the verb חזr, hazah ("see a vision") that actually occurs in Amos 1:1; either נבא may legitimately refer to Biblical prophecy. See 1 Sam. 9:9 for a similar type of distinction, between the terms nביא, navi ("prophet") and ("seer").

8 The Biblical text reads that Amos' prophecies occurred "two years before the earthquake." Eliezer says that Amos foresaw the earthquake, interpreting, as it were, that natural phenomenon either with the "roaring" of the LORD mentioned in the following verse, or perhaps with some of his other prophecies (see 9:1). Thus Eliezer chooses to understand the earthquake not simply as a time-referent, presumably included by the redactor for the reader's benefit. Rather, he relates to the event as a Divine-induced disaster, foreseen by prophetic vision. Paul (1991), 36 makes a similar connection: "The occurrence of this earthquake, which was interpreted as a fulfillment of some of his prophetic oracles, most probably authenticated his being accepted as a true prophet and thus was cited in the introduction to his book."

${ }^{9}$ Eliezer interpolates a brief comment into the Scriptural text he cites.

${ }^{10}$ Eliezer's explanation here is based on the language of Psalms 18:7-8.

11 This first comment on 1:3 serves as Eliezer's introduction to the prophecy that follows, in that he refers to the entire passage (1:3-2:6ff). 
great length and the essence of his prophecy is about them. ${ }^{12}$ Damascus will be struck first with her, ${ }^{13}$ by Tiglath-pileser, King of Assyria, as is related in Kings. ${ }^{14}$ Some of (Amos's) prophecy concerns the destruction by Assyria, and some of it concerns the destruction of Nebuchnezzar, King of Babylonia.

For three sins of Damascus, and even for ${ }^{15}$ four I will not punish it: its explanation: ${ }^{16}$ they have greatly transgressed against me, and many times the kings of Aram did evilly to my people, all throughout the days of the kings of Israel. And with regard to all of those instances, ${ }^{17}$ I suffered (their sins), and I did not return their just recompense on their heads, i.e., to decree destruction against them. But on account of their threshing my people, the inhabitants of Gilead ${ }^{18}$ with threshing-boards of

12 Of course, Amos doesn't really relate to Judah to any significant degree; even discounting the modern scholarship that views the Judah oracle $(2: 4-5)$ or references to Judah (e.g., 6:1) as spurious, the main thrust of Amos' prophecy is surely about Israel (see 7:15). However, Eliezer doesn't appear to make that distinction here.

13 I.e., with Israel.

${ }^{14} 2$ Kings 16:9.

15 My translation of the prefixed vav in this manner ("and even for") instead of other conjectured meanings (the conjunctive "and" or the adversative "but" are usually proposed) is based on Eliezer's subsequent comment. Thus, Eliezer parses the verse (and would presumably do so for all of the subsequent verses with the same formula $[1: 6,9,11,13 ; 2: 1,4,6])$ as if reading "for three sins of (the specific nation) I will forgive, and even for the fourth I shall not punish. But for (all of the subsequent enumerated sins in each case)..., i.e., I will punish the nation." See Eliezer's comment on 1:6, below. For a full discussion about the proper exegesis of the phrase "for three, for four," see Paul (1991), 27-30 (however, I disagree with his judgment about Eliezer's interpretation, 29, n. 188).

16 Eliezer employs the term פתרון, pitaron (the MS actually contains an abbreviation), which is one of the standard twelfth century rabbinic terms for "context." I have addressed this term and principle of exegesis in a number of places; see Robert A. Harris, "Structure and Composition in Isaiah 1-12: A Twelfth-Century Northern French Rabbinic Perspective," in "As Those Who Are Taught": The Interpretation of Isaiah From the LXX to the SBL (Claire Mathews McGinnis and Patricia K. Tull, eds., Atlanta: Society of Biblical Literature, 2006), 171-87 (176-77).

${ }^{17}$ I.e., for the three and four sins that are not enumerated.

18 Again, Eliezer intersperses his own words into the Biblical text. In this case, he indicates that it is Aram's cruelty specifically to Israel that has finally incurred God's wrath. 
iron, ${ }^{19}$ to cut their bodies with terrible tortures, I will not remain silent, but I will pay them their recompense.

1:4: I will send fire upon the House of Hazael: through the hand of Tiglath-pileser, King of Assyria.

1:5: The gate-bars of Damascus: before the King of Assyria, that he may enter.

The Valley of Aven...Beth Eden: These are [places in] Aram. And these are the children of Aram that are spoken of in Kings. ${ }^{20}$

Kir: Towards Kir. ${ }^{21}$ To the place from which they came, as it is written and Aram from Kir (Amos 9:7). In the same way that Scripture says of Israel The LORD will send you back to Egypt (Deuteronomy 28:68), so will these people return to the place from which they came. That is what is said in Kings and exiled them to Kir (2 Kings 16:9). ${ }^{22}$

1:6: For three sins of Gaza: And even for the fourth I will yet not turn aside their recompense, ${ }^{23}$ but will suffer all that which they did evilly to my people. But because they exiled my people an exile complete and total, in that they did not allow to remain a remnant or a refugee in their land, but delivered the refugees of my people who had escaped to them,

${ }^{19}$ Eliezer has interpolated a synonym for "threshing boards," מורג, morag, from Isaiah $41: 15$, to help clarify his sense of the figurative language.

${ }^{20}$ It is not clear what Eliezer is referring to here, as the phrase bnai aram does not appear in Scripture. Perhaps the reference is to the "raiding bands" (gedudai Aram) mentioned in 2 Kings 6:23; 24:2. Cohen (2012), 101 thinks Eliezer refers to 2 Kings 19:12-13, because of the reference there to bnai 'Eden, "the children of Eden" and its possible association in Eliezer's mind with bet eden, "House of Eden" in Amos here. It may well be that Eliezer has in mind a midrash found in Sifre Devarim, at Deuteronomy 11:21: this interpretation features a reference to Aram "trampling (Israel) to dust" in 2 Kings 13:7, the very verb Amos uses here.

${ }^{21}$ Eliezer thus demonstrates his knowledge of this aspect of Biblical Hebrew grammar: the name of the city or region to which the Arameans are to be exiled is written קירה, Kirah in Hebrew, and the final hé indicates direction. Certain commentators (Rashi) had apparently considered "Kirah" to be the actual name.

22 See 2 Kings 16:9: "The king of Assyria marched against Damascus and captured it. He deported its inhabitants to Kir."

${ }^{23}$ I.e., God had not yet, at that stage, decreed destruction against Gaza. 
to Edom, who hated them, and who delivered them to Assyria and to the Chaldeans, to lead them into captivity - concerning this I will not remain silent, but I will send fire upon the wall of Gaza.

1:9: And they did not remember the covenant of brothers: i.e., of Solomon and Hiram, who became brothers by means of a covenant. ${ }^{24}$

1:11: And as for Edom, what was to become of him ${ }^{25}$ Therefore does it say: For three sins of Edom.... And repressed his compassion: From having compassion on his brother during his trouble. And he raged incessant against his brother (with) his anger, that he had against his brother, and he kept his wrath forever.

\section{1:13: Because they ripped open the pregnant women of Gilead: Even} the fetuses in the womb of their mothers would they pierce to destroy any male among them, that they might expand their border. ${ }^{26}$

${ }^{24}$ See 1 Kings 5:26: "There was friendship between Hiram and Solomon, and the two of them made a treaty." See also 1 Kings 9:12-13, where Hiram calls Solomon "my brother."

25 Although Eliezer does not explicitly justify his question, I believe he formulated his comment in this way as a type of argumentum minores ad maiores (Rabbinic qal vahomer): If the LORD condemned the violation of a brotherly covenant between Israel and Tyre, how much the more so would he condemn the violation of actual brotherhood existing between Israel and Edom (see v. 11, here). The sense of betrayal felt by Israel and Judah against Edom, more, perhaps, than against their "foreign" enemies, is seen most vividly in Psalm 137:7-9. This animus continued, figuratively, into the post-biblical world inherited by both ancient and medieval rabbis. See Gerson Cohen, "Esau as Symbol in Early Medieval Thought," In Jewish Medieval and Renaissance Studies (Alexander Altman, ed., Cambridge, MA: Harvard University Press, 1967), 19-48.

26 Eliezer might be thinking of Jeremiah 49:1: "Concerning the Ammonites. Thus said the LORD: Has Israel no sons, Has he no heir? Then why has Milcom dispossessed Gad, And why have his people settled in Gad's towns?" Both Rashi and R. Yosef Kara, Eliezer's predecessors, direct their readership to this verse. 


\section{Chapter Two}

\section{2:1: Because he burned the bones of the King of Edom to lime: Instead} of wood, to take revenge on account of the son of the King of Moab, who was burned as a whole burnt offering, when the Moabites couldn' $\mathrm{t}^{27}$ break through to the King of Edom. ${ }^{28}$

2:6: Because they have sold, for silver, [the righteous]: ${ }^{29}$ The poor innocent who was acquitted in court - they would sell him his own acquital, for they would only acquit him if he would give them a bribe, and he had to buy his acquital from them in order for them to see him locked and closed up in the clutches of his adversary in court, who had had no evidence ${ }^{30}$ against him. ${ }^{31}$ And also there is in its contextual sense $e^{32}$ that they would sell

${ }^{27}$ I have accepted Poznanski's emendation of what appears to be a confused reading in the manuscript of Eliezer's commentary; see Poznanski (1913), 144, n. 1.

${ }^{28}$ Eliezer is interpreting in light of the narrative in 2 Kings 3:26-27: "Seeing that the battle was going against him, the king of Moab led an attempt of seven hundred swordsmen to break a way through to the king of Edom; but they failed. So he took his first-born son, who was to succeed him as king, and offered him up on the wall as a burnt offering. A great wrath came upon Israel, so they withdrew from him and went back to their own land."

29 The end of the verse is not actually found in the manuscript, in the comment's incipit.

${ }^{30}$ Lit., "mouth."

31 Eliezer follows his predecessors Rashi and R. Yosef Kara, who based their interpretation on the Aramaic Targum. This ancient rabbinic translation had rendered the MT ve-evyon ba'avur na'alayim ("and the needy, for a pair of sandals") as ve-hasikhaya bedil deyahsenun ("and the poor, so that they might take possession of/hoard up/lock up [his property]”), perhaps reflecting a different Hebrew model (נעלם?). For a discussion of the meaning of this difficult vocable, see Paul (1991), 77-79.

32 Heb. משמעו, mashma'o. This is one of several terms employed by the northern French rabbinic exegetes to indicate departure from the older rabbinic, "midrashic" understanding of Scripture. This term is somewhat analogous to the way contemporary Christian exegetes might use the term sensus litteralis. Among rabbinic exegetes, the more common term is פשוטו, peshuto or פשט, peshat; if either term is encountered in the eleventh century commentaries of Rashi, we might best translate the term as "plain meaning" (as opposed to midrash). However, by the twelfth century, when Eliezer wrote his commentaries, we can be more certain in translating the term as "context." Again, see Harris, "Concepts of Scripture in the School of Rashi," in Jewish Concepts of Scripture: A Comparative Introduction, 102-22. 
the merit of the innocent to the one who opposed him in court, by means of a money-bribe, in order that he would be locked ${ }^{33}$ and closed up and transmitted into their hands, in so far as he didn't have an advocate in court. And also one should say that since he was locked and closed up against his will, and in hunger, and deprived of everything, they would drive him away from his merit and from his inheritance, by means of money, ${ }^{34}$ and they would have no compassion upon him to pledge to him whatever he lacked. ${ }^{35}$ The result would be that the estate of the righteous heir, who had merited it from his ancestors, would be turned over to others. Not only that, but they would steal it outright from him; that is what is said.

2:7: They aspirate ${ }^{36}$ over the dust of the earth: they aspirate and stretch on the dust of the earth, as a snake who aspirates and desires and stretches to bite people on their heel. In this way they aspire to bite the heads of the poor, and suck up and swallow them. (This they do) on the dust of the earth, for (Scripture) has chosen ${ }^{37}$ the example of a snake who lies in

33 It may be that, in presenting the biblical text's נעלים, na'alayim ("sandals" as though it were a reference to the poor man being "locked up" (נעולים, n'ulim), Eliezer is understanding wordplay to be present in the prophetic rhetoric. However, he generally will articulate the presence of wordplay in a composition through the expression לשון נופל על לשון, lashon nofel al lashon, literally, "tongue/language falling on tongue/language." For a full discussion on the awareness of paranomasia in Eliezer's exegesis, see Harris (1997), 221-51; and Robert A. Harris, "Twelfth-Century Biblical Exegetes and the Invention of Literature," in The Multiple Meaning of Scripture: The Role of Exegesis in Early-Christian and Medieval Culture (Ienje van 't Spijker, ed. Leiden; Boston: Brill, 2009), 311-29 (327).

${ }^{34}$ I.e., a bribe.

${ }^{35}$ Eliezer evokes here the language of Deuteronomy 15:8.

36 The meaning of the participial השואפים, ha-shoafim, has long eluded translators and commentators. It is perhaps best translated as "(those) who trample"; see Paul (1991), 79-80, who demonstrates that the biblical verb "is not to be confused with its homonym, שא, sha'af ('to gasp, pant after')." But that is not how Eliezer takes it. My translation follows Eliezer's interpretation, and I have endeavored to provide a wordplay that connects some constructions of Biblical Hebrew שאף as well as one of its postbiblical meanings, "to aspire to do something."

${ }^{37}$ Literally, "he has seized" (תפ, tafas). As I have shown, this expression is one of Eliezer's ways for indicating the role of a biblical redactor in the composition of Scripture: the redactor (or compiler or author) "seizes" a certain expression or form to shape the biblical text, thus contributing a human dimension into the Divine message. See, e.g., Eliezer's commentary on Amos 8:5 (below), and Isaiah 36:1 (elsewhere in this volume). For a full discussion of Eliezer's understanding of biblical redaction, see Harris (1997), 208-20. 
wait. And so Scripture says: he stoops, he crouches (Psalms 10:10).$^{38} \mathrm{He}$ lies in wait so that no one will see him and he can spring upon them, as is the case in: they crouch in their dens, lie in ambush in their lairs (Job 38:40).

And the way of the poor - and the downtrodden - do they pervert. This is similar to the context of: they chase the needy off the roads; all the poor of the land are forced into hiding (Job 24:4), for on account of their fear they turn aside from the road, (as in) and wayfarers went by roundabout paths (Judges 5:6). ${ }^{39}$

And a man and his father: a man after his father.

2:8: On garments) taken in pledge - from widows and the poor - do they recline: they make a bed and lie down on their pledges.

By every altar: even by the altar(s) of the high places that they make for my name, to sacrifice their sacrifices.

And the wine of the fined: of those who were fined and overwhelmed through injustice and robbery.

2:9: And - behold - I destroyed the Amorite before them, etc. ${ }^{40}$

2:10: And they rob and do violence to the downtrodden and lowly among them, and they would have done well to remember that I took them ${ }^{41}$ up out of the land of Egypt, out of the house of bondage, ${ }^{42}$ out of the hand

38 Although this citation does not afford Eliezer a linguistic connection to the verse in Amos, it does provide a thematic connection. See the previous verse (Psalms 10:9): "he lies in wait secretly...to sieze the poor."

39 Eliezer's explanation echoes Rashi's, and the latter had cited the same verse in Job.

${ }^{40}$ Poznanski (1913), 144, n. 4, postulates that the manuscript containing Eliezer's comments on 2:9 may be deficient at this point. While this of course is possible, Eliezer's inclusion of the word "behold" may in fact be his only gloss, indicating his awareness that a new unit of discourse (a casus pendens) begins with the verse. As Shalom Paul formulates the thought: "Now comes a dramatic reversal introduced by an emphatic anokhi ["I"]. Roles are reversed and Israel becomes the object." See Paul (1991), 87 (and esp. n. 436).

${ }^{41}$ Eliezer is bound to change the MT "you" to "them" because of his third-person expansion of the Biblical text.

${ }^{42}$ Eliezer, perhaps unconsciously, echoes Exodus 20:2. 
of those who robbed them and who oppressed them. Thus they should not have defrauded and afflicted orphans and widows.

And I led you through the wilderness forty years: And you should have had compassion upon and sustained the poor, as I did for you, when I took care of you ${ }^{43}$ for forty years until I enabled you to inherit the land of the Amorites. Thus you should not have dispossessed and driven off the poor and the orphans from the inheritance of their ancestors.

2:11: And I raised up, from among your sons, prophets - to reprove you and to teach you the way of goodness and uprightness, and, from among your young men, nazirites - to become sanctified for my name, that you should not sin against me.

Is that not so, $\mathbf{O}$ children of Israel?: i.e., that I sanctified you for My name, and that you are all equal in this holiness?! Yet I have accomplished nothing!

2:13: (I will) hinder (you): [In Old French]: "Retenant," [i.e., "restrain"].44 This is related to the word "parapet." ${ }^{45}$ Similar to this is you have put affic-

43 Alternatively, “when I dealt with you”; literally, "when I rolled you.” Eliezer employs this unusual verb according to its use in rabbinic, as opposed to Biblical, Hebrew. See BT Yebamot 48b. The use of the verb in Jeremiah 51:25 is not analogous.

${ }^{44}$ Poznanski (1913), 144, n. 5, notes that the medieval Hebrew dictionary of Menahem ibn Saruk, the Mabberet, interprets in this way and, presumably, that may have influenced Eliezer (see following footnote). See also Greimas (1992), 524-25. A medieval Hebrew-Old French glossary offers a different equivalent for the same Hebrew word: "engoysant," meaning "to weigh heavily upon, to oppress." See Banitt (1972), 429. The northern French rabbinic exegetes, Eliezer among them, regularly employed the tactic of translating difficult words and phrases into their contemporary French vernacular; see Menahem Banitt, Le Glossare De Bale: Introduction (Jerusalem: The Israel Academy of Science and Humanities, 1972); idem., "Exegesis or Metaphrasis," in Creative Biblical Exegesis: Christian and Jewish Hermeneutics Through the Centuries(JSOT Supplement Series 59; Benjamin Uffenheimer and Henning Graf Reventlow,eds. Sheffield: Sheffield Academic Press, 1988), 13-29. On the broader phenomenon of a medieval French-speaking Jewish community, see Kirsten Anne Fudeman, Vernacular Voices: Language and Identity in Medieval French Jewish Communities (Philadelphia: University of Pennsylvania Press, 2010).

${ }^{45}$ In other words, Eliezer is relating the unique verb מעיק, me'iq in Amos 2:13 to the equally unique noun מעקה, ma'aqeh, which appears in the Bible only in Deuteronomy $22: 8$. While it may be true that there is an orthographic similarity between the two voca- 
tion $^{46}$ upon our loins (Psalm 66:11), and the oppression ${ }^{47}$ of the wicked (Psalm 55:4). In any event, the context of the passage proves the meaning of the word here: (God will hinder Israel) as the wagon that is full of grain is hindered and is held up in its place, that is driven in its heaviness and is unable to move/go quickly.

2:14: Flight shall fail the swift: So he will no longer be able to walk quickly.

2:15: He shall not stand in the way of bowmen, who set themselves on a high place to shoot and to draw (their bows). ${ }^{48}$

His life: This harkens back as much ${ }^{49}$ to swift of foot as it does to

bles, it is surprising that Eliezer would compare these two texts, since there does not appear to be a semantic equivalence between them. There does, however, appear to be such a connection between the text in Amos and his next two citations. It is, moreover, curious that he refers to Deuteronomy 22:8, in light of the treatment by the Mahberet Menahem. This medieval Biblical Hebrew dictionary, composed by Menahem Ibn Saruq, was the only formal lexicographic tool at Eliezer's disposal and, indeed, it appears to inform Eliezer's choice of citations here. Menahem divided his presentation of the word into two sections. In the first, he placed only the word in Deuteronomy 22:8, whereas in the second, he included the three remaining passages (Amos 2:13; Psalms 55:4 and 66:11). See Angel Saenz-Badillos, ed., Menahem Ben Saruq: Mabberet (Granada: Universidad de Granada, Unversidad Pontificia de Salamanca, 1986), 289. Modern Biblical scholarship has suggested various suggestions for understanding the word; for a survey, see Paul (1991), 94.

46 The word that connects Psalm 66:11 to this verse in Amos is מועקה, muaqah.

47 The word that connects this verse to the one in Amos is עקת, aqat.

${ }^{48}$ Eliezer abbreviates the Biblical idiom לדרוך קשת, lidrokh keshet, which means "to draw" or "to bend" the bow (i.e., by stepping on it); see, e.g., Jeremiah 50:14; Psalms 11:2. In his description of the bowman's tactics, it is possible that Eliezer is reflecting upon the realia of warfare as he understood it in his own day. See Yehoshafat Nevo, "Descriptions of Realia in the Commentaries of Rabbi Eliezer of Beaugency," [Hebrew] Sinai 99:1-2 (1986): 1-5.

${ }^{49}$ Eliezer uses what is for the northern French exegetes a common technical term, מוסב, musav; literally, this means "turns on," but it conveys the sense of "corresponding to" or occasionally "harkening back to." It is a term through which the exegetes point to linguistic or literary allusion between two passages that are not immediately contiguous but which, in their eyes, have a legitimate (as opposed to a fanciful, midrashic) connection. Here, Eliezer observes that Amos' phrase, "shall not save his life" functions in "double duty," and refers as much to "swift of foot," at the beginning of the verse, as it does to the phrase's immediate antecedent, "rider of horse." 


\section{rider of horse..$^{50}$}

2:16: Naked shall he flee: Even though he is naked and should therefore hide out of shame in the clefts of the rocks, ${ }^{51}$ until the battle should pass and no one would see him, he shall flee and not be concerned for any shame, out of fear of being killed.

\section{Chapter Three}

3:1: Whom I brought up out of the land of Egypt: when they were supposed to serve me.

3:2: That is why I call you to account for all of your iniquities: since you should have remembered my acts of lovingkindness and my goodness that I showed you more than any other people, whereas you rebelled against me. Why did you command the prophets not to prophesy?52 If only one prophet had prophesied to you, you might have been able to say that "this mission was not from the Omnipresent, but rather he spoke from his own heart." But many prophets prophesied to you, who had not ever seen one another, and what one prophesied, so did the other, and all of the prophets who prophesied since the days of Jeroboam son of Nebat did so with the same essential message. ${ }^{53}$

${ }^{50}$ In other words, Eliezer is saying that the word נפשו, nafsho, "his life," found at the end of the verse in specific reference to the horse rider but not in the middle of the verse with regard to the fleet-footed, functions as a double-duty term: in the same way that the horse rider shall not escape with his life, so shall the aforementioned "fleet-footed" individual not escape with his life.

${ }^{51}$ Eliezer alludes to the language of Isaiah 7:19.

52 Eliezer adopts the language of Amos 2:12.

53 This should perhaps be translated as "all of them had one style" or "manner of expression” (סגנון אחד להם, signon ehad lahem). Eliezer's interpretation is derived from,

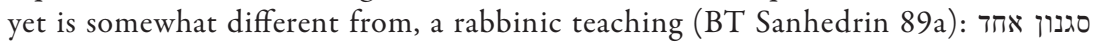
עולה לכמה נביאים ואין שני נביאים מתנבאים בסגנון אחד "one (Divine?) manner of expression arises to many prophets, but no two prophets prophesied with the same (human?) manner of expression." Moshe Greenberg translates סגנון, signon, as "communication," and observes that the Hebrew term comes from the Latin signum, or "watchword." See Moshe Greenberg, "Jewish Conceptions of the Human Factor in Biblical Prophecy," in Justice and the Holy: Essays in Honor of Walter Harrelson (Douglas A. Knight and Peter J. Paris, eds., Atlanta: Scholars Press, 1989), 145-62 (411). 
This would have been impossible were it not I who had summoned them for this purpose. ${ }^{54}$

3:3: Can two walk together to one place, with one counsel and with one matter without having met beforehand for that purpose? (For example ${ }^{55}$ ), if the friends of Job had not met or been summoned or arranged among themselves one day beforehand ${ }^{56}$ to go and comfort him, how had they gone together with one heart and with one counsel to wander there to comfort him? So with regard to two prophets: how would they go with one mission, to speak one matter in my name, if I had not designated them and summoned them? Indeed, Jeremiah was in the Land (of Israel) and Ezekiel was in the Land of Babylonia, both of them prophecying one matter, and they (i.e., the people) should have recognized that I had sent them both. And should you (Israelites) ${ }^{57}$ say, "So what?! We shall be safe, even if we follow our own willful heart, and no evil shall befall us." 58

3:4: ${ }^{59}$ Does a lion roar in the forest without a purpose to his roar or without captured prey? It would never happen! For in the forest, in the place

${ }^{54}$ Even if Eliezer doesn't evoke the language of Jeremiah 7:25-26 here, he does seem to rely on the content of that message: "From the day your fathers left the land of Egypt until today, though I kept sending all my servants, the prophets, to them daily and persistently, they would not listen to me or give ear." Eliezer's comment here is unusually long for him. He may be trying to "fill out" the concise divine indictment of Amos 3:1-2 with a fuller justification of the stern decree.

55 These words do not appear in the Hebrew text. However, it is reasonable to assume that a strictly contextual ("peshat") commentator like Eliezer would not consider that the prophecy of Amos "actually" referred to the visit of Job's friends (see Job 2:11-13), nor does appear to be referring to some no longer extant midrash that connected that visit with Amos' rhetoric, as Poznanski (1913), 145, n. 1, suggests. Rather, it seems more likely that Eliezer is adducing a Biblical example that substantiates his explanation of the verse.

56 Eliezer here employs the language of Lamentations 2:22.

57 I clarify here only because the construct ואם תאמרו, ve-im tomeru, "and if you should say," is a rabbinic locution, often found in a medieval commentator's address to his own audience. Eliezer here transfers the rabbinic idiom into Biblical rhetoric, in an effort to clarify the flow of Amos' speech.

${ }^{58}$ In teasing out what he thinks is the intention of the prophetic rhetoric, Eliezer paraphrases the language of Deuteronomy 29:18 and Jeremiah 23:17.

${ }^{59}$ Here, Eliezer does not clearly mark between verse and commentary; rather, he expands what he considers to be an allusive, laconic Biblical composition, carrying over 
of many wild animals, at his roar - they are terrified at his voice, that he is coming to tear them! If that is so, it is impossible that the Omnipresent would likewise roar, and that his roar would not grip ${ }^{60}$ you! And should you (Israelites) say: many animals hear the (lion's) voice, and they escape and are saved, so too we will save our lives from the evil, that it should not cleave to us ${ }^{61}$ and we will find sanctuary in Assyria and in Egypt. Therefore is it said:

3:5: Does a bird fall on a trap of the ground: ${ }^{62}$ Behold you are like birds who are ensnared in a hidden trap, for they do not recognize it; so, too you will be caught at the time of evil, when it shall fall upon you suddenly. ${ }^{63}$ And suddenly you shall fall in a trap, and you shall not recognize it and you will not escape from it again without snare and capture, in the same way that it is impossible for a bird to escape from the trap without the snare, for it is impossible for the trap to alight from the ground, from the place of its hiding, unless it has caught, surely caught something. So on account of what are you confident and why do you not tremble?

3:6: Who has ever seen it from of old that if a ram's horn is sounded in a town on account of a rumor that is heard in the land, ${ }^{64}$ to alarm the people, and the people do not tremble? My prophets are blowing the ram's horn and sanctifying fasts and calling for solemn assembly ${ }^{65}$ on account of the "rumor" that they heard from me - and yet you do not tremble?!

thoughts from one verse to another. To be sure, there are no verse numbers or divisions in the sole surviving manuscript copy of his commentary, nor does he always work from a clear Biblical incipit; see Introduction.

${ }^{60}$ Amos uses this verb (צלח, $t z-l-h$, "to rush, break out"), and in this same conjugation, in 5:6. However, here, my sense of Eliezer's intent is to follow NJPS as it renders the verb in such passages as Judges 14:6 ("The spirit of the LORD gripped him") or 1 Samuel 10:6 ("The spirit of the LORD will grip you").

${ }^{61}$ Eliezer relies on the language of Genesis 19:19.

${ }^{62}$ For an explanation of this translation, see Paul (1991), 110.

${ }^{63}$ Eliezer's Hebrew is slightly awkward here, as he weaves the third person text he paraphrases from Koheleth 9:12 into the second person address he preserves from the Biblical rhetoric of Amos.

${ }^{64}$ Eliezer roots his comment in the language of Jeremiah 51:46.

${ }^{65}$ See Joel 2:15. 
And even though you see the evil that is coming to the Land, why do you not fear, that you should say it was a coincidence that happened to you ${ }^{66}$

Can evil happen to a town - sword and pestilence and famine - and the LORD has not caused it? Of course he caused it! And he did so to chastise you, and to bare your ears to instruction, so that you may return from iniquity. ${ }^{67}$ And the evil that comes upon you - it is from him, according to the word that he spoke to you by his servants.

3:7: Indeed, the Lord GOD ${ }^{68}$ does nothing without having revealed his secret beforehand ${ }^{69}$ to his servants the prophets, and when the prophets hear his words, they are not able to remain silent without rebuking and prophesying. ${ }^{70}$ For even if -

3:8: A lion has roared, who among all the beasts would not fear ? ${ }^{71}$ And he said (so) to the people that the word of the Lord would enter into their hearts as ${ }^{72}$ a burning fire, shut up in their bones, and they would not be able to hold it in - to withstand it and not speak ${ }^{73}$ - but would be helpless. And you should not have hated them ${ }^{74}$ for this, but should have heard and repented.

${ }^{66}$ Eliezer evokes the language of 1 Samuel 6:9.

${ }^{67}$ Eliezer evokes the language of Job 36:10.

${ }^{68}$ In my translation, I have chosen to follow Masoretic convention. The word "GOD," entirely capitalized, represents the Divine Name YHWH; it is in the second position, following the Hebrew word for "Lord."

${ }^{69}$ Eliezer has inserted this one word into his presentation of the verse, perhaps in keeping with his comment on 3:3, above.

${ }^{70}$ See Jeremiah 20:7ff.

${ }^{71}$ Poznanski (1913), 146, n. 2, emends, conjecturally, adding: "and how much the more so if the Lord GOD has spoken, who would not prophecy?"

72 The following italicized text is a virtual citation of Jeremiah 20:9; Eliezer has merely changed the pronomial suffixes to fit the language of his commentary on Amos 3:8.

ונלאתי Here Eliezer is essentially commenting on the somewhat elliptical phrase כלכל, ve-nileti kalkhal, in Jeremiah 20:9; his explanation, that the prophet was unable to hold back the word of God, ultimately derives from his teacher Rashbam's explanation of the verb ונל-א-י) in such passages as Exodus 7:18.

${ }^{74}$ I.e., Amos tells the people that they should not hate the prophets who, after all, cannot but convey to them the reproof of God. 
3:9-10: Proclaim to the people about the dealings of the palaces that are in Ashdod and that are in the Land of Egypt - they that are filled with lawlessness and rapine,$^{75}$ and say: gather on the hills of Samaria ${ }^{76}$ and see the great outrages within her, who are murdered and injured more than than in the palaces of Ashdod... and Egypt, and who are more oppressed in her midst. ${ }^{77}$ And with all of the roarings that I roared to them through the agency of My prophets, ${ }^{78}$ and with all of the evils that I brought upon them, they were not chastised nor did they know how to act right and straightforward in order to be corrected, for their heart is involved in chasing after the reward with which they might be rewarded, ${ }^{79}$ they who store up lawlessness and rapine in their palaces.

3:11: An enemy, and around the land (he is): Enemies shall come upon them, and around the land shall they encamp, as in the (following) context: ${ }^{80}$ The LORD has commanded against Jacob his enemies all about him (Lamentations 1:17).

And he will bring down from you your strength: I.e, the high and fortified walls of your strength, in which you trusted, ${ }^{81} \mathrm{I}_{\text {will bring down }}{ }^{82}$ to the earth, as in the (following) context: and brought down its mighty

75 Eliezer's use of this phrase ("lawlessness and rapine," from Amos 3:10) is a clear indication that he is commenting on more than one verse at a time.

${ }^{76}$ Here, Eliezer moves back to verse 9.

77 Eliezer's commentary on this verse is a perfect example of how he interjects his observations into the flow of the Biblical text, both adding to and detracting from it, in order to clarify what he considers to be a laconic text.

78 See verse 8 .

${ }^{79}$ Eliezer's use of the word "reward" is, of course, fraught with irony, as it is in fact punishment that awaits those who "store up lawlessness and rapine."

${ }^{80}$ Eliezer chooses yet another term to express the idea of "context" here, ענין, inyan. For a brief discussion of the importance of this term in commentaries that address the contextual meaning of Scripture, see Robert A. Harris, Discerning Parallelism: A Study in Northern French Medieval Jewish Biblical Exegesis (Providence, R.I.: Brown Judaic Studies, 2004), 16-17, n. 5.

${ }^{81}$ Eliezer evokes the language of Deuteronomy 28:52 ("your high and fortified walls in which you trust").

${ }^{82}$ Since Eliezer has altered the Biblical text from the third to the second person, so, too, has he re-conjugated the verb of this passage. 
stronghold (Proverbs 21:22). This is the tower of strength ${ }^{83}$ in which you trust, and despoiled and plundered ${ }^{84}$ shall be your palaces - they that are filled with lawlessness and rapine. ${ }^{85}$

3:12: Two shank bones: These are the legs. The tip of an ear: This is the "horn" 86 of the ear. And these are the least of the limbs, and all of the essentials are eaten.

And so shall the Israelites be saved, who dwell in Samaria complacent and secure and lying on ivory beds $s^{87}$ with (only) ${ }^{88}$ an edge ${ }^{89}$ of a bed and

${ }^{83}$ See Judges 9:51.

${ }^{84}$ By his inclusion of this word ("plundered"), Eliezer may be unconsciously influenced by the language of Ezekiel 26:11.

${ }^{85}$ Eliezer's repetition of the phrase "lawlessness and rapine" (three times in as many verses), even though the phrase appears only once in context, may be his way of articulating the importance of the Biblical text's repetition of the word "palaces." See Paul (1991), 118-19.

${ }^{86}$ Eliezer's suggested identification, קרן האזן, qeren ha-ozen, "horn of the ear," is obscure, and there is no such common Hebrew idiom for "ear part" (in general, Amos 3:12 is an exceedingly difficult verse). I suggest here three possible, though admittedly tenuous, solutions: 1. Eliezer's use of qeren is similar to its use in the Hebrew expression, קרן זוות, qeren zavit, the "smallest part" of an angle, thus, he thinks that the biblical phrase refers to the "smallest part" of the ear; see, e.g., the use of the word meaning "a lush part of a vineyard" in Isaiah 5:1. 2. It is influenced by Latin cornu, either "corner" or "horn," thus, "corner of the ear." Note that Jerome renders Hebrew קרנות המזבח "cor, qarnot ha-mizbeah, "the horns/corners of the altar" (e.g. at Exodus 29:12) as cornua altaris. 3. Eliezer's word represents some version of Arabic (or Maltese) q-r-n, the "hard part" of the ear (as with horned-beasts). This is semantically equivalent to Targum Jonathan's Aramaic rendering (which Eliezer would have known), חסיס, has-hes, "the hard cartilage of the ear." All of these have some semantic-assonant association with Eliezer's gloss. I am grateful for the counsel of Aharon Maman, good friend and sage linguist, for his contributions to this footnote.

87 See Amos 6:1.

${ }^{88}$ Paul (1991), 120, clarifies what is also made explicit in Eliezer's subsequent comment: "the reference to the parts of the bed are meant to indicate the paltry pieces of property that the wealthy Israelites will barely manage to save, this and no more."

89 This word (פאה, pe'ah, here in the construct form has been translated as "corner" (KJV); "head" (RSV); "leg” (NJV). From Eliezer's subsequent comment ("they will save only the פאת of a long bed and two legs"), it is probable that he has in mind what we would call either the "head-board" or the "base-board" of a bed. 
lolling upon their couches (Amos 6:4) ${ }^{90}$ with (only) a head/leg ${ }^{91}$ of a couch. And nothing shall be saved except for these least parts. And out of all of their wealth and all of their pleasure-goods, they shall save nothing except for the edge of a long bed and two legs. ${ }^{92}$ And similarly with regard to the head/leg of a couch, since both a bed and a couch are each types of beds, and according to their differentiation in construct and purpose, what (Scripture) calls with regard to bed - edge, it calls with regard to couch - head/leg. You are compelled (to interpret) that since bed and couch are parallel to one another, and since edge is juxtaposed to bed, and head/ leg is juxtaposed to couch, that their juxtapositions and their parallelism testify to their meaning. ${ }^{93}$ And you have no rule in (interpreting) Torah greater than "a matter learned from its context." ${ }^{14}$ And the prophet saw

${ }^{90}$ In referencing this verse, which describes the beds upon which the Israelites lay oblivious to their wrongdoings, Eliezer connects the punishment to be suffered by the Israelites with one of the means by which they sinned.

91 This word (דמשק, damesheq) is a famous crux interpretum. Eliezer, as will be made clear presently, is aware of the difficulty; he relies both on his understanding of Biblical parallelism, and on the primacy of using context to explain Scripture, to offer his interpretation. Thus, Eliezer deduces that פאה המשק and the more common, both refer to similar parts of a "bed" or "couch." I have translated "head/leg," since Eliezer does not specify which "edge" of the bed he thinks the word refers to. I have treated this comment at greater length in Harris (2004), 82 and see n. 20, there.

92 Eliezer uses here the same unusual word (כרעים, kir'ayim) for "legs" employed by Amos in the verse.

93 I.e., that דמשק, dאה משה interpretation, also invoking Biblical parallelism, is cited by R. Yosef Kara in the name of Eliezer's teacher, R. Samuel ben Meir (Rashbam).

${ }^{94}$ Eliezer invokes here the twelfth of the "Thirteen Rules of R. Ishmael" for interpreting Scripture. These modes of exposition actually form the introduction to the earliest extant rabbinic midrash on Leviticus, called the Sifra. See Jacob Neusner, ed., Sifra: An Analytical Translation (Brown Judaic Studies, Number 138. Atlanta: Scholars Press, 1988), 57-63. A standard treatment of "Rabbinical Hermeneutics" may be found in Hermann Leberecht Strack and Günter Stemberger, Introduction to the Talmud and Midrash (Marcus Bockmuehl, trans., Minneapolis: T \& T Clark; Fortress Press, 1996), 15-30. There is some question whether the "Thirteen Rules" are truly as old as the Tannaitic Midrash to which they now form an introduction; certainly, it has long been demonstrated that the presumably corresponding " 32 Rules of R. Jose Ha-Galili" date from after the rise of Islam. See Moshe Zucker, "Towards a Solution to the Problem of the Thirty-Two Rules and the 'Mishnah of Rabbi Eliezer," Proceedings of the American Academy for Jewish Research 23 (1954): Hebrew Section, 1-39. However one might choose to date any of the lists of rabbinical hermeneutic rule list, it is nonetheless true 
this in that he rebukes the inhabitants of Samaria about their palaces and their beds and their couches, ${ }^{95}$ and that is the language that he chooses here. And (the phrase) the edge of a bed... harkens back to (so shall the Israelites) be saved. ${ }^{96}$

3:14: (I will visit punishment) on the altars of Beth-El in which (the Israelites) trust, and they shall know that "a lie is in their right hand."

3:15: I will strike the winter house together with the summer house: that (the Israelites) made for their enjoyment.

The ivory houses: that are built on the crag of the rocks, ${ }^{98}$ as in your neck is like a tower of ivory (Song of Songs 7:5).

\section{Chapter Four}

4:1: Cows of Bashan: (These are) the women, the blissful and joy-filled princesses. ${ }^{99}$

Who oppress the poor: This is like the matter of Jezebel; they coerce their husbands to take that which belongs to others. ${ }^{100}$

Bring the sheep and cattle of a poor man and let us make a feast, and they refrain from taking their own sheep and cattle. ${ }^{101}$

in any case that the rule about context to which Eliezer refers here was not invoked either principally or frequently until the twelfth century.

95 See Amos 6:4.

${ }^{96}$ In other words, Eliezer states that the essence of this verse is, "so shall the Israelites be saved - possessing nothing more than the edge of a bed."

${ }^{97}$ Eliezer paraphrases such Scriptural texts as Isaiah 44:20 and Psalms 144:8, 11.

${ }^{98}$ Literally, "teeth of the rock." Eliezer employs the terminology of 1 Samuel 14:4. Note: the Hebrew word for tooth," שו shen, is the same as the word for "ivory," which both figures in the verse he glosses here as well as the one he subsequently cites from Song of Songs (he has also just referenced Amos 6:4).

99 See Isaiah 32:9. Eliezer echoes Rashi here.

100 See 1 Kings 21:15, 25.

101 The end of Eliezer's comment is paraphrasing the language of 2 Samuel 12:4. He renders the Bible's ונשתה, ve-nishteh (lit. "let us drink") as "let us make a feast"; the 


\section{4:2: He will carry you off: ${ }^{102}$ (you who are) on Mount Samaria (Amos 4:1). ${ }^{103}$}

In baskets: ${ }^{104}$ This is like take one container ${ }^{105}$ (of manna) (Exodus 16:33). From the contextual meaning of pots, (it is apparent that the prophet) doubled the expression. ${ }^{106}$ It is also like "in baskets and in pans." 107

Hebrew word for "feast" (משתה, mishteh) comes from the same Hebrew root. Eliezer probably magnifies the scope of the sin implicit in the verb ונשתה both on account of Nathan's parable in 2 Samuel 12:4 as well as to better justify the prophet's condemnation of the women referred to in Amos 4:1. Eliezer's comment may be contrasted with that of R. Yosef Kara, who renders the verse: "however you manage to find it - even by stealing - bring us wine that we may drink" (איך שתמצאו אפילו בגזל הבא לנו יין ונשתה).

102 See Amos 6:10, and Eliezer's comment there.

${ }^{103}$ Eliezer clarifies that the prophet directs this message of doom to the people whom he addressed in the previous verse, which he effectively re-cites here.

${ }^{104}$ I have translated according to Eliezer's first explanation in his comment on the verse; see below for his alternative interpretation. The word is a famous crux interpretum: see the judgment of Shalom Paul (1991), 130: "The remainder of this verse abounds in lexical difficulties that have given rise to varied suggestions that attempt to understand the prophet's vivid - yet problematic - description of the impending doom of Samaria's privileged class... the first crux is tzinot." On 132, Paul reviews Eliezer's interpretation; on 133, he similarly presents Eliezer's understanding of דוגה סירות, sirot dugah, i.e., "fishing-pots."

105 Eliezer thus makes a connection between צניות, tzinot, here in Amos with the morphologically similar צנצנת, tzintzenet, in Exodus.

106 Once again, Eliezer relies on his understanding of Biblical parallelism for philological purposes. Since he is not certain what the Hebrew word צנות, tzinot means, he relies on his understanding of the word סירות, sirot, in its parallel position in the verse, to guide him in his explanation.

107 This would be a wonderful prooftext for Eliezer - only the verse does not exactly exist as Eliezer (or the scribe of the manuscript?) cites it! As Poznanski notes in the editio princeps $(1913,147, \mathrm{n} .2)$, Eliezer probably had in mind 2 Chronicles 35:13: בסירות ובדודים ובצלחות, "(the sacred offerings they cooked in) pots, cauldrons and pans." Thus, the cited verse contains ובדודים, uvadwadim, "cauldrons" - but not the hopedfor בצנות, "baskets." In any event, he thus understands the somewhat enigmatic term צנות as "basket-like containers." In the history of Jewish exegesis, only R. Jonah Ibn Janah and R. Judah Ibn Balaam preceded him in offering this explanation; however, as those scholars wrote in Arabic, a language that Eliezer did not know, it is likely that his is an independent, if similar, explanation. For an introduction to both Ibn Janah and Ibn Balaam, see Aharon Maman, "The Linguistic School: Judah Hayyuj, Jonah Ibn Janah, Moses Ibn Chiquitilla and Judah Ibn Balam," in Hebrew Bible/old Testament: The History of Its Interpretation. Volume I: From the Beginnings to the Middle Ages (Until 1300). Part 2: The Middle Ages (Magne Saebo, ed. Gottingen: Vandenhoeck \& 
And your end: and at the end you will be within it, (as if) in fishing pots. This is like the context of it is the pot and we are the meat (Ezekiel 11:3); the corpses that you have piled ${ }^{108}$ up in it are the meat for which it is the pot (Ezekiel 11:7); it shall not be a pot for you, nor you the meat in it (Ezekiel 11:11). (In other words), the hill of Samaria shall be for you as a pot and, moreover, they ${ }^{109}$ shall be in it as a fish being cooked - and disintegrated from an abundance of cooking! Scripture analogizes the cooking done by men, who are strong, as (cooking of) "meat," whereas the cooking of women, who are softer, Scripture analogizes as (cooking of) "fish." 110 And it is an allegory, ${ }^{111}$ just like the one in Ezekiel, to indicate that subject to the sword and to hunger shall they be within it. ${ }^{112}$

One might also say that this word בצנות is like shield and buckler (Ezekiel 23:24), ${ }^{113}$ i.e., that they shall carry out the dead on shields with contempt, ${ }^{114}$ and they will cast them outside the wall. And their end ${ }^{115}$ shall be that

Ruprecht, 2000), 261-81.

108 Eliezer has again apparently misquoted his prooftext, although here with less consequence than in the previous example. Our MT of Ezekiel 11:7 has שמתם, samtem, translated by NJPS as "piled up"; Eliezer has הרביתם, hirbetem, meaning "multiplied." As medieval exegetes generally cite from memory, they occasionally misquote their prooftexts; citations such as these are rarely the result of variant versions.

${ }^{109}$ Eliezer switches to third-person in his paraphrase.

110 See Eliezer's explanation of Amos 4:1 as referring to women. Thus, Eliezer explains the difference in the figurative language ascribed to men in Ezekiel (see 11:2) and to women in Amos.

111 Eliezer uses the word משל, mashal, perhaps here meant more generally as "figurative language." However, at least one contemporary rabbinic exegete, R. Joseph of Orleans (Bekhor Shor), transliterated the very term as allegoria; see the latter's commentary on Numbers 12:7-8 in Menachem Cohen, Mikra'Ot Gedolot 'Haketer': A Revised and Augmented Scientific Edition of 'Mikraot Gedolot' Based on the Aleppo Codex and Early Medieval MSS: Numbers (Ramat Gan: Bar Ilan University, 2011), 75.

112 I.e., within the "hill," or "city," of Samaria.

113 I follow the translation of these military terms found in Greenberg (1997), 481. KJV, RSV, and NJPS all translate "buckler and shield."

114 The same explanation is offered by several modern commentators; see Paul (1991), 130-31.

115 Here, Eliezer has reformulated the verse's "and your end." 
the enemy attacking the city shall drag ${ }^{116}$ and scratch them with thorns, ${ }^{117}$ i.e., with intertwined thistles, in which flesh is caught and is torn. This is like: they shall take hold of the multitudes in the midst of the earth (Genesis 48:16). According to its context, this means "they shall grasp" the multitudes in the midst of the earth. ${ }^{118}$ And so it is (with respect to) they shall catch them (Jeremiah 16:16), i.e., they shall hunt them and catch them. Thorns: the same meaning is found in before your thorns grow into a bramble (Psalms 58:10).

And he shall carry: the same meaning is found in and if someone's kinsman - who is to burn incense for him - comes to carry (the bones out of a house) (Amos 6:10). And it is the way of this prophet to speak hyperbolically. ${ }^{19}$

4:3: And on account of the famine shall they go out from the city through the breaches, each woman ${ }^{120}$ straight ahead of her, on account of the great number of breaches, so that they would not have to go around and to spread out to find a gate or opening through which to go out, for each one would be able to go out straight ahead of her. This is like the context of and the people shall advance, every man straight ahead (Joshua 6:5). And upon their going out they would all be thrown, dragged and thrown forth (see Jeremiah 22:19) at the bottom of the Mount, ${ }^{121}$ beyond the cracks and openings, and there the beasts of the field and the birds of the sky shall consume their carcasses, as in the case of Jezebel. ${ }^{122}$

4:4: Present your sacrifices the next morning: on the morrow of the vow-offering, without delay, whereas with Mine you were tardy.

116 The MS is not clear for this word; Poznanski (1913) and Cohen (2012) transcribe it differently.

117 Eliezer thus offers here, as he seldom does, an alternative interpretation. Earlier, he had explained Hebrew סירות, sirot, as "pots"; here, as "thorns." Both are legitimate understandings of the Biblical Hebrew term; see Paul (1991), 132-33.

118 Eliezer states that the word Amos uses here, דוגה, duga, has the connotation of "grasping," as in the appearance of the assonant word וידגו

119 Eliezer observes that prophets typically employ figurative language.

120 These are the "cows" Amos addressed in 4:1.

121 Thus, Eliezer understands the word הרמונה, harmona, to mean "mountain," presumably Mount Samaria (see 4:2).

122 See 2 Kings 9:36-37. 
On the third day: On the third day after the taking the tithe of herd and flock. And since sometimes this was scrawny, and they would not select them as they would a votive offering, but rather (they would take) the tenth, however it came out, and they would to feed it and fatten it, he has chosen (the wording) the third day. But in any case, it means without delay.

4:5: And burn a thank-offering without ${ }^{123}$ leaven: Without leaven, but rather with everything (i.e., in the meal-offering accompanying the thankoffering) made out of matzah, so as not to interfere and cause delay.

And proclaim freewill offerings...to the people, that they should volunteer and bring their sacrifices. For so do you love to sacrifice - at Gilgal and Beth-el, but not at My temple (in Jerusalem). ${ }^{124}$

123 Eliezer understands the prefixed-mem here as privative, not partitive; contrast Paul (1991), 141, n. 20. In other words, rather than interpreting the phrase תודה, ve-qater me-hametz todah, as is typically done, to mean "burn a thank offering from that which is leaven," he prefers to understand it as "burn a thank offering [the usual way, i.e., with unleavened bread], rather than with leavened bread." It is not clear why Eliezer seems driven to interpret in this way. Although leaven was typically forbidden as an agent in sacrifice (see, e.g., Leviticus 2:11), it was certainly permitted to offer a thanksgiving sacrifice together with leavened bread (see Leviticus 7:13). It seems rather that Eliezer is stressing, as he had in his previous comment, that the prophet is bidding the Israelites to perform these rites without delay, and, as is well-known from the Exodus narrative (see Exodus 12:34, 39) preparing matzot, or unleavened bread, takes less time than preparing leavened bread. Poznanski (1913), 147, n. 7, supports Eliezer's reading through reference to such passages as Jeremiah 48:45 (and also Rashi's comment on that verse).

${ }^{124}$ Eliezer's understanding of Amos' indictment in 4:5 (i.e., that the Israelites are sinning in worshipping at sites other than the sanctuary in Jerusalem) while having the benefit of the contextual mention of these sites in 4:4, misses what many moderns understand as prophetic irony regarding the cult. Contrast Paul (1991), 141: "According to Amos, the entire panoply of cultic worship can never replace...morality. The externalities of the ritual cannot take the place of correct ethical behavior. The cult fulfills their needs...not the Lord's." See also James Luther Mays, Amos: A Commentary (Philadelphia: The Westminster Press, 1969), 75-76; and Hans Walter Wolff, Joel and Amos: A Commentary on the Books of the Prophets Joel and Amos (Philadelphia: Fortress Press, 1977), 211-12. Cf. Francis I. Anderson and David Noel Freedman, Amos: A New Translation With Introduction and Commentary (New York: Doubleday, 1989), 434-35. 
4:6: Cleanness of teeth: (This results) from the withholding ${ }^{125}$ of food. And every instance of cleanness connotes emptying, wiping away, and "scrubbing."

4:7: And also I: And also...I have withheld, moreover, from you... ${ }^{126}$ when it was yet three months before harvest time: i.e., when the crops still had to ripen and become full; and before their very eyes food was cut off. ${ }^{127}$

I would make it rain: And even when I would make it rain on one town and not another; even on that town one field would be rained upon (but not another). Yet since I didn't want yet to finish you off completely, I would cause rain to fall (at least) on one town.

4:9: Furthermore I added to you another plague: ${ }^{128}$ I struck you with blight: Furthermore, I continued to strike you in your bodies; perhaps you would turn back? ${ }^{129}$

4:10: I sent against you pestilence - suddenly - on the road ${ }^{130}$ to Egypt, when you went there for help; perhaps you would turn back.

Furthermore, I slew with a sword your young men together with the captured of your horses that you took out from Egypt (for the purpose

125 Reading מריחוק, m'rihuq, "from the withholding of," instead of מדיבוק, m'dibuq, "from the cleaving to," with Poznanski (1913), 148, n. 1. "Cleanness of teeth" in this context is not a hygienic reward, but rather an indication of lack of food.

${ }^{126}$ Eliezer has deftly reread the verse through the repetition of one word (וגם, ve-gam, "and also") and the elimination of another word (אנכי, anokhi, or "I," which pronoun is also contained within the verb in Biblical Hebrew and so is not needed to understand the verb) and the addition of the word עוד, od, which I have translated here as "moreover." The effect of this is to rush the connection between the punishment announced in v. 6 with the continued threats articulated in v. $7-8 \mathrm{ff}$.

${ }^{127}$ Eliezer's language echoes Joel 1:16.

${ }^{128}$ In this comment, Eliezer makes clear that he does not see 4:9 as a separate, independent oracle. Rather, he reads it as a continuation of the previous speech.

129 I.e., repent.

${ }^{130}$ Eliezer construes the Hebrew דרך, derekh, as an actual road, as against most modern translations and commentaries which interpret "in the manner of." Anderson and Freedman (1989), 443, raise as a possibility what is in essence Eliezer's interpretation, and cite Jeremiah 2:18 as a prooftext. 
of) fighting and fleeing from the enemy when they took captives among you on the road. And I placed your carcasses with the carcasses of your horses $^{131}$ until it arose, the stench of your camps, and also in your nostrils did it arise, ${ }^{132}$ for even you yourselves were so disgusted with your carcasses that they became a loathsome thing to you, and you cast them away. ${ }^{133}$

4:11: I added yet another plague upon you, when I overthrew among you cities, like God's overthrowing of Sodom and Gomorrah, which shall not be sown nor shall it sprout, ${ }^{134}$ (and which shall be) without a man dwelling in them (Jeremiah 4:29). And you have become, those remaining, beaten and struck like a firebrand plucked out of the burning, and you should have felt it and turned back.

4:12: Therefore thus I will do to you: This matter ${ }^{135}$ will I apply to you, i.e., to overturn you and to destroy your land, as I had begun (in the beginning of this oracle). Because...: That since thus will I do to you, your heart shall be humbled through trouble: ${ }^{136}$ Prepare your heart to meet your God, O Israel!

4:13: Behold, He who formed the mountains, And created the wind with which to destroy the mountains and hills, by drying up all of their grass. ${ }^{137}$

131 Eliezer echoes the language of Leviticus 26:30.

132 By repeating the verb "to arise" in his commentary, Eliezer cleverly interprets the prefixed conjunctive vav ("and") at the beginning of the Hebrew ובאפכם u-veapekhem. This conjunction is generally ignored in the translations and commentaries. An exception among the latter is Wolff (1977), 210, note s. Among the medieval rabbinic commentaries, only Radak follows Eliezer's lead.

133 Eliezer alludes to the language of Numbers 11:20 and Isaiah 34:3.

${ }^{134}$ Eliezer evokes the threatened punishment for national abandonment of the covenant found in Deuteronomy 29:21-27 (esp. v. 22).

135 This phrase apparently refers to the six punishments God has announced through the prophet in v. 6-11.

136 Eliezer adapts the language of Psalms 107:12.

137 Thus, in the midst of the so-called "doxology," Eliezer explains why "created the winds" follows "formed the mountains," i.e., the winds would be the means through which God would destroy the mountains. On the doxologies of Amos, see Paul (1991), $152-56$. 
Has told man equitably, ${ }^{138}$ that he might seek retribution against him. What his thought is: i.e., what was his issue, his words, his ways with him, up until now. Behold... ${ }^{139}$ he turns for you blackness into daybreak: this is like in gloom and deep darkness (Job 28:3). ${ }^{140}$ And behold..., he treads for you upon the high places of the earth, and has brought down the pride of your power. ${ }^{141}$

\section{Chapter Five}

5:2: To rise: To rise. ${ }^{142}$ On her soil: Among the children of her people. With none to lift her up: Out of all of the children of her people.

5:5: For Gilgal shall go into exile: This is wordplay. ${ }^{143}$

${ }^{138}$ Lit., "by juridical decision," so to speak; Eliezer's gloss indicates his awareness that on occasion, prophetic oracles function as though in a legal context. See Yochanan Muffs, "Who Will Stand in the Breach? A Study of Prophetic Intercession," Love and Joy: Law, Language and Religion in Ancient Israel (New York and Jerusalem: The Jewish Theological Seminary, 1992), 9-48.

139 By repeating the word הנה, hineh, "behold," both in his comment here as well as in the next clause, Eliezer makes it clear that he understands the verse as containing three distinct statements about God's actions and their results.

140 Thus it may be presumed that Eliezer understood the subject of Job 28:3 as referring to God, not man. This is still a matter of disagreement; see the translations and commentaries.

${ }^{141}$ Eliezer has conflated such texts as Leviticus 26:19 and Ezekiel 30:6 in his commentary.

142 Although it appears that way in English translation, Eliezer is not simply repeating the words of Scripture. The Hebrew pum, found in the verse, is an infinitive construct which might mistakenly be understood as a gerund ("rising"). Eliezer clarifies this by converting it into לקום, la-qum, an infinitive prefixed with a preposition ("to rise").

143 The rabbinic expression for paronomasia that Eliezer employs is "tongue falling on tongue" (or "language falling on language"). The prophet plays on the name Gilgal by announcing הגלגל גלה יגלה, ha-Gilgal galo yigleh; this might be rendered for effect, in English: "Gilgal will go into galut ('exile')." Rashi had previously pointed out the wordplay in the verse and, following Eliezer, Radak likewise calls attention to it; however, both of these exegetes invoke different technical discursive language. For an examination of the role of wordplay in Eliezer's exegesis, see Harris (1997), 221-51; also Harris (2009), 327. For a discussion of wordplay in this specific passage of Amos, see Paul (1991), 162-63. For an article on the role of wordplay in biblical composition, see Edward L. Greenstein, "Wordplay, Hebrew," in The Anchor Bible Dictionary (David Noel Freedman, ed., New York: Doubleday, 1992), 968-71. 
5:6: Else He will rush to consume like fire upon the House of Joseph. ${ }^{144}$

5:7: And righteousness to the ground do they hurl: This is similar to the context of it cast truth to the ground (Daniel 8:12).

5:8: Who made the Pleiades and Orion: This harkens back to Seek the LORD, and you will live (Amos 5:6). "Pleiades" and "Orion" direct the sphere of the Zodiac, and according to them is the world conducted for evil and for good, for peace and for war, for sustenance and for starvation, and for every matter, month by month, year by year. ${ }^{145}$ For this reason (Scripture) joins them together in every place. ${ }^{146}$

Who turns into dawn the deep darkness: And in his hand (is the power) to do evil or to do good to all.

Who calls to the waters of the sea: At the generation of the Flood, ${ }^{147}$ whereas you should have revered him.

5:9: Who strengthens: Who gives strength. ${ }^{148}$ Ruin: Pillage and destruction. Upon the strong: And so you should not have trusted in power and strength and wealth and honor, nor on fortresses.

144 That is, it is not, e.g., fire's quality of heat that the prophet invokes, but rather, its ability to completely consume.

${ }^{145}$ In his belief in the power of the zodiac, Eliezer reveals himself a typical medieval thinker. Rabbi Abraham ibn Ezra, an older contemporary of Eliezer, goes to great lengths in his commentary on Amos 5:8 to address the astrological implications he finds therein. For a thorough examination of this commentary, and of the ancient rabbinic antecedents to medieval belief in astrology referenced in it, see Simon (1989), 209-17.

146 See Job 9:9; 38:31.

${ }^{147}$ Eliezer seems influenced by a midrashic approach in this comment, a rare occurrence in his exegesis. The ancient midrash, Bereshit Rabbah (23:7), had already noticed that the phrase "Who summons the waters of the sea And pours them out upon the earth - His name is the LORD!" appears twice in Amos (here, in 5:8 and later, in 9:6). See Poznanski (1913), 148, n. 8.

148 Eliezer follows the Targum and the earlier commentators of the northern French school (Rashi, R. Yosef Kara) in interpreting this rare verb. See Paul (1991), 169 , who reviews several possibilities, yet concludes that "a completely satisfactory solution has yet to be found." 
5:10: They hate in the gate: This phrase harkens back to who turns [into wormwood - justice] (Amos 5:7). But since he wanted to say you have turned into wormwood - justice, therefore [he adds]: has not the Omnipresent made the Pleiades and Orion and turned into dawn - the deep darkness; and day into night [does he darken] (Amos 5:8), and turns into dry land - sea, ${ }^{149}$ and so will he overturn upon you (that which) corresponds to your overturning, and ruin upon fortresses will come (Amos 5:9) upon them, since they hate in the gate - the arbiter. ${ }^{150}$ In the gate: In the place of justice and righteousness.

5:11: Because your trampling is upon the poor: In [courts of] justice, to take his house and his inheritance. A portion of grain do you take from him: Illegally. [In Old French]: "Rente," [i.e., "a payment"], a portion of $\operatorname{tax}^{151}$

5:12: [You troublers of] the righteous: i.e., those [who ought to have been found] innocent in court. You taker of bribes: To pervert his judgment. ${ }^{152}$ The needy: i.e., those [who ought to have been found] innocent in court. In the gate: [In the place of] their judgment. They have subverted: For conviction. ${ }^{153}$

5:13: Therefore, the one who is enlightened and who understands their great and many crimes at that time when catastrophe shall befall them shall remain silent and shall justify My judgment, that in justice does it come upon them, for it is an evil time for them. ${ }^{154}$

149 See Psalms 66:6.

${ }^{150}$ Eliezer interprets verse 10 as though concluding the thought begun in verse 7 . His comment seeks to account contextually for the content of the intervening verses.

151 Poznanski (1913), 149, n. 1; Greimas (1992), 517 (see also 515). Thus, Eliezer understands the "portion of grain" taken from the poor to be a kind of unfair "tax."

152 I.e., to pervert the judgment of the righteous person, just mentioned in the verse.

${ }^{153}$ Eliezer thus takes the oracle of Amos 5:12 as an indictment of the corruption of Israelite courts of law, where those who ought to have been found innocent of charges have instead been convicted unjustly. In this he follows the Aramaic Targum, and his French predecessors Rashi and R. Yosef Kara.

${ }^{154}$ Eliezer's comment on 5:13 is a parade example of how he interweaves his own comments into Scripture, expanding what he regards as laconic language into a more fully comprehensible text. 
5:14: That [the LORD] may...: That therefore the LORD, God of Hosts, may be with you, as you say now. But with regard to your evil deeds, He will not be with you, as you thought when you said "peace will be ours." 155

5:15: Rather, hate evil and love good. Perhaps: perhaps. ${ }^{156}$ The remnant of Joseph which remains from the hand of the kings of Aram and Assyria. Joseph [is the term by which] he calls all of Israel, on account of the kingdom of Jeroboam and the sanctuary of Beth El in its territory. ${ }^{157}$

5:16: The farmer cries out in his plowing with the oxen, according to the way of mourners. ${ }^{158}$

5:17: And in all vineyards: For they were accustomed to sing, as in the context of in the vineyards no songs are sung, no cheering is heard (Isaiah 16:10). For I will pass through your midst: for judgment.

5:18: Ah, you who wish for the day of the LORD!: Who say to the prophets: Where is the word of the LORD? Let it come! (Jeremiah 17:15) [Who say]: may He speed, may He hasten his purpose, that we may see it! (Isaiah 5:19). ${ }^{159}$ [It is darkness], and not light: i.e., it is darkness that will not yield to light, since many successive troubles, one after the next, will be in it.

155 Eliezer echoes the language of Deuteronomy 29:18.

${ }^{156}$ Here Eliezer has rendered biblical Hebrew אולי ulai, with its rabbinic Hebrew equivalent שמא, shemma. Perhaps he considered the latter more recognizable to his readership. The dim hope held out by the prophet in this verse is seen in BT Hagigah 4b, "When Rabbi Ashi reached this verse, he would begin crying, 'All this and (only) perhaps!' [כולי האי ואולי, kulai hai ve-ulai]”; cited in Paul (1991), 178 n. 187.

157 In other words, Eliezer understands the name "Joseph" to stand for the northern kingdom of Israel.

158 Eliezer thus takes "farmer" to be the collective subject of the sentence, as opposed to a majority of the translations and commentaries, which understand it as the object. Cf., e.g., RSV: “They shall call the farmers to mourning." For a survey, see Paul (1991), 179 n. 203-4.

159 Eliezer has essentially expanded here upon the comment of Rashi, who likewise drew upon the analogy of Isaiah 5:19. 
5:19: A bear attacked him; ... a snake bit him!: [This happened] when they thought they could escape and be saved.

5:20: $\mathrm{So}^{160}$ is not the day of the LORD darkness without ${ }^{161}$ light.

5:21: For behold, ${ }^{162}$ I loathe, I spurn your festivals, even when you celebrate them to my Name. [I will not favorably acknowledge] ${ }^{163}$ your solemn assemblies: i.e., the sacrifices of your solemn assemblies, which you solemnize before me.

5:22: Your meal offerings: [And should you offer me]... your meal offerings. ${ }^{164}$ The fellowship offering [of your fatlings]: This is the [singular] form of the [more common plural form] "fellowship offerings." 165

5:23: The sound of your songs that you sing to me.

${ }^{160}$ By the inclusion of the word "so," Eliezer makes clear the connection to Amos 5:19: the day of the LORD will not save Israel of its troubles, but will itself be a calamity.

${ }^{161}$ Eliezer has paraphrased the biblical Hebrew nominal sentence "Is not the day of the LORD darkness, and not light?" (חשך ולא אור, hoshekh ve-lo or) as "Is not the day of the LORD darkness without light" (חשך בלא אורה, hoshekh b'lo orab). He has also substituted Late Biblical Hebrew/Rabbinic Hebrew אורה , orah, for Biblical Hebrew אור, or, both of which mean "light." The sum total of this subtle gloss is to observe that although the day of the LORD has the characteristic of night, because it is dark, it is nonetheless a day, one, however, without light.

162 As before, by the inserting these words, Eliezer has made the connection between vv. 18-20 and vv. 21-27 clearer.

${ }^{163}$ Literally, "smelling" (understood transitively, i.e., inhaling), figuratively understood as "receiving favorably." On the Hebrew אריז, ariah, understood in this way, see Paul (1991), 189 and n. 10 there.

${ }^{164}$ By repeating the initial verb of the verse before his citation "your meal offerings," Eliezer insures that the reader does not understand a chiastic structure for the first part of the verse, i.e., "for should you offer me your burnt offerings, [also] your meal offerings will I not desire." Eliezer presumably notices the chiastic structure of vv. 23-24, which immediately follow. Elsewhere, I have demonstrated Eliezer's awareness of chiastic parallelism; see Harris (1997), 271-72 and Harris (2004), 79-80.

165 Amos 5:22 contains the only occurrence in the Bible of the singular form of the term for this type of sacrifice (shelem). Ibn Ezra's comment here is similar to Eliezer's, but more fully expressed: "This is the singular form, for from shelamim ("offerings"), which is the plural form, one would say shelem, which is the singular form." 
5:24: But let [justice] roll down like water: that goes forth through the streets and courtyards, for it is through this [i.e., justice] that you shall be saved.

\section{5:25: For behold, did you bring me animal sacrifices and grain offerings} in the wilderness those forty years, that in this you were saved from your enemies (Numbers 10:9), and I was a wall for you, ${ }^{166}$ and dread of you fell upon all the earth?! ${ }^{167}$ Not on account of the sacrifices and the offerings were you saved, even though you brought sacrifice and offering, but rather on account of the justice and righteousness [you practiced] and the laws and statutes [you observed]. ${ }^{168}$

5:26: And you shall carry off: This harkens back to is not the day of the LORD darkness (Amos 5:20), when successive catastrophes shall come upon them. And you shall carry off the mold of your king: (This is to be understood within) the context of "molten image." Your king: (This is to be understood) from the context of "Molech." ${ }^{169}$ And the form of

166 See Zechariah 2:9.

167 Eliezer alludes to the language of Joshua 2:9.

168 This rhetorical question posed a problem, particularly for the medieval Jewish reader, in that the Torah recounts several instances of Israelite ritual sacrifice during the wilderness period (see, e.g., Exodus 24:5-9; Leviticus 9:8-21; Numbers 9:4-5). Eliezer solves the difficulty in a most clever way. Although he admits that the Israelites indeed offered sacrifices in the wilderness, as the Torah indicates in many places, he stresses that these were voluntary, and that it was through performance of justice, not ritual behavior, that they were saved. In this way he builds on Rashi's explanation: "Do I want sacrifices and offerings?! Is it not true that in the wilderness I did not speak with your ancestors to bring me sacrifices; I said, When a person wishes to offer...(Leviticus 1:2) - when he wants to offer. But the Torah says, Let the Israelite people offer the passover sacrifice at its set time (Numbers 9:2); this teaches that Israel only offered that passover sacrifice alone (as a commandment)." Ibn Ezra presents the difficulty between Amos 5:25 (and similar prophetic sentiments), and the Torah's and subsequent Jewish tradition regarding Israelite sacrifice in the wilderness; his ultimate resolution, stressing the primacy of ethical behavior and the performance of the commandments over ritual, is similar to Eliezer's. See Uriel Simon, Abraham Ibn Ezra's Two Commentaries on the Minor Prophets: An Annotated Critical Edition. Volume One: Hosea, Joel, Amos. [Hebrew] (Ramat Gan: Bar Ilan University Press, 1989), 224-28.

${ }^{169}$ Eliezer thus clarifies that the reference to "king" in the speech of the prophet refers not to God, but to the cult of Molech (see Leviticus 18:21; Jeremiah 32:35, etc.). Whether or not there actually was such a cult is beyond our scope; for a discussion, see 
your images: The preparation ${ }^{170}$ of the forming of a face. [In Old French]: "Enformement" [i.e., "formation"]. ${ }^{171}$ The star [of your "god"]: The gleaming of the lightning of the face of your "god," that you made out of gold and precious stones, as in the context of so that it would be [like] lightning [that has been polished] (Ezekiel 21:15), and as in the context of a star has gone forth (Numbers 24:17). It is an arrow, polished and burnished, as in the context of flashes $^{172}$ of the bow (Psalms 76:4). ${ }^{173}$

5:27: I will exile you with them. ${ }^{174}$

Jacob Milgrom, Leviticus 17-22: A New Translation With Introduction and Commentary (New York: Doubleday, 2000), 1551-64.

${ }^{170}$ Eliezer makes a connection between the word Amos uses here, כיון , kiyyun, as though it were connected to the Biblical Hebrew root $ו---כ, k-v-n$, which can mean "to prepare, to establish."

${ }^{171}$ Poznanski (1913), 149, n. 7; Greimas (1992), 203. Thus, Eliezer does not understand the terms Sikkuth and Kiyyun in Amos 5:26 as the proper names of foreign deities, but rather has interpreted them as generic objects of idol worship. This is in contrast with Rashi, who comments "Sikkuth/Kiyyun/Kokhav: these are names of idol worship." According to Eliezer's commentary, the verse would be rendered, "And you shall carry off your the mold of your Molech and the form of your images, / the star of your 'god' that you made for yourselves..." This comment seems remarkably in consonance with the rendering of the Vulgate: "et portastis tabernaculum Moloch vestro et imaginem idolorum vestrorum sidus dei vestri quae fecistis vobis," "the tabernacle of your Moloch and the form of your idols, the star of your god which you have made for yourselves." However, the similarity may well be only coincidental.

172 Or "arrows."

173 Continuing as before, Eliezer interprets the elusive phrase "star of your god" as a reference to some sort of object of idol worship and not an actual celestial object. He supports this contention essentially by citing texts (Ezekiel 21:15 and Numbers 24:17) that use the terms "lightning" and "star" as metaphors.

${ }^{174}$ I.e., with the objects of idol worship that Eliezer has identified in 5:26. 


\section{Chapter Six}

\section{6:1: Ah, you who are at ease in Zion and confident on the hill of} Samaria: and who are not concerned about the fracture of Joseph (Amos 6:6). ${ }^{175}$ Nor have they paid attention to the breaches that the kings of Aram and the kings of Assyria have breached; and they become weaker (2 Samuel 3:1) whereas the nations become more powerful; and they say "there will be peace for me." ${ }^{176}$ And they take delight and luxuriate in their palaces, as it relates further on. ${ }^{177} \mathrm{He}$ particularly chides the kings of [the House of] David and Israel, as they were the notables, first of the nations, the upper-class and chiefs of all the nations of the earth (Deuteronomy 28:1).

They come to them: to these two kingdoms, does the whole House of Israel [come], and all of them are bowed down, and they come to them for judgment, and [the kings] are supposed to deal with righteousness and justice towards all their people, ${ }^{178}$ and to go out and come in before them ${ }^{179}$ and teaching them the good and upright path. ${ }^{180}$ For behold -

\section{6:2: Cross over to Calneh... and Great Hamath and... Gath of the} Philistines: For they are the heads of nations and kingdoms now, like Zion and Samaria. Are they better than these two kingdoms, more than Zion and Samaria? You should have worshipped Me and walked in My ways, on the good and broad land ${ }^{181}$ that I gave you! Or is their territory greater than your territory that you would be able to say that their god

175 Eliezer's citation of these words from v. 6 apparently indicates his view that the opening section of the prophet's oracle ends with this phrase, and that vv. 1-6 form a rhetorical unit leading into v. 7. This is borne out through reference to his comment on the beginning of v. 7 (see below).

176 Eliezer invokes the language of Deuteronomy 29:18.

177 Or, "as it makes explicit further on"; see vv. 4-6. This expression, indicating narrative flow directs the reader to check the immediate context for an explanation of a problematic word or phrase. It is one of the key formulas employed by the northern French rabbinic practitioners of peshat, contextual exegesis.

178 See 2 Samuel 8:15.

179 See Numbers 27:17; Deuteronomy 31:2.

${ }^{180}$ Eliezer adduces the language of 1 Samuel 12:23 (see also Psalms 25:8).

${ }^{181}$ Eliezer invokes Exodus 3:8, though not quoting it precisely. 
is greater and stronger than I, to cause goodness to his worshippers more than I can?! And for this [reason] you worship their gods?!

6:3: Who cast off: who put far away, their day of evil, saying, evil shall not come to us, nor the sword nor hunger shall we see (Jeremiah 5:12), and draw near ${ }^{182}$ the seat of violence.

6:4: And they do not pay attention that their end is to be struck, but rather they lie on beds of ivory, and sprawl... [(This last word), in Old French]: "Estendiléz," [i.e., "they stretched themselves out"], ${ }^{183}$ in the way of pride and (over) confidence.

6:5: They stammer: This is the language of "breaking off the song." 184 [In Old French]: "Refraint," [i.e., "refrain"]. ${ }^{185}$ The cessation of the melody, as in (do not gather) the broken-off (grapes) of your vineyard (Leviticus 19:10). ${ }^{186}$

6:6: And the choicest oils: (This is) the oil of choicest spices (Exodus $30: 23$ ), for all of the choice spices are in them (i.e., the oils). ${ }^{187}$

182 At first blush, Eliezer's tactic is somewhat of a curiosity: he renders the biblical text's $ש-\lambda-\lambda, n-g-s h$, which in the hif'il (causitive) conjugation appears thirty-seven times in the Hebrew Bible, with a verb, $ב-7-p, q-r-b$; that in the pi'el conjugation (intensive, but here analagous to a causitive) appears a mere seven times. Both mean "cause to draw near." Perhaps Eliezer is calling the reader's attention to the difference between $\boldsymbol{E}-\boldsymbol{\lambda}$-J, $n-g-s h$, in the hif'il conjugation, and the qal and/or the nif'al, all of which bear orthographic similarities that the inattentive reader might not pick up.

183 Poznanski (1913), 150, n. 3; Greimas (1992), 248.

${ }^{184}$ Eliezer understands the biblical root ט-ר, $p$ - $r$-t, "to break off into separate parts" (which is its typical meaning in rabbinic Hebrew), perhaps analogous to the way one who stammers breaks his thoughts into speech that does not flow.

185 Poznanski (1913), 150, n. 4; Greimas (1992), 509.

186 The second part of Eliezer's comment is similar to the explanation of two of Eliezer's predecessors, Rashi and R. Yosef Kara, each of whom refers to a Spanish Jewish lexicographer (Menahem ibn Saruq and Dunash ibn Labrat, respectively). For Menahem, see Saenz-Badillos (1986); for Dunash, see Angel Saenz-Badillos, ed. Tesubot De Dunas Ben Labrat (Granada: Universidad de Granada, Unversidad Pontificia de Salamanca, 1980). See also Saenz-Badillos's A History of the Hebrew Language (John Elwolde, trans. Cambridge: Cambridge University Press, 1993). On the difficulty of translating the hapox legomenon verb הפורטים, see Paul (1991), 206.

187 Eliezer references Exodus 30:23-25 (see 25:6). If so, Eliezer thus understands 
But they are not concerned about the fracture of Joseph: This is as I have explained it (in my comment) above. ${ }^{188}$

6:7: Therefore: On account of their taking (illicit) enjoyment, and not being concerned about the fracture of ${ }^{189}$ my people. Now: In a short period of time. They shall be exiled at the head of those (being) exiled: Those king ${ }^{190}$ shall be exiled at the head of those being exiled, first, along with the officials. ${ }^{191}$

It shall pass away, that mourning-banquet ${ }^{192}$ of stretching out: This carries the contextual meaning of "lying down," from the context of and they sprawl on their couches (v. 4). And so it is as well in do not come into a house of the mourning-banquet (Jeremiah 16:5), a house of a terminally-ill person, ${ }^{193}$ who lies down and stretches out to die.

the anointing mentioned in Amos 6:6 in the context of a condemned religious ritual

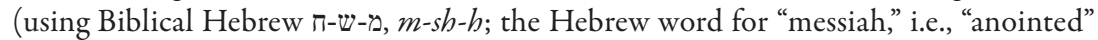
comes from the same root), as opposed to a private anointing (usually expressed with

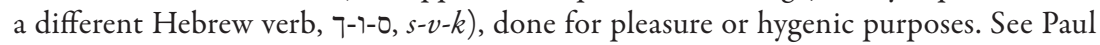
(1991), 208.

188 See Eliezer's comment on Amos 6:1: "Nor have they paid attention to the breaches that the kings of Aram and the kings of Assyria have breached."

189 Again, by this citation of the previous verse; by his summary of the charges against the people contained in vv. 1-6; and, as well, by his attention to the wordplay on the word ראש, rosh ("choice," "head," "first") in vv. 1, 6 (and 7), it is clear that Eliezer presents vv. 1-6 as an integral unit, leading up to the punishment announced in verse 7 .

${ }^{190}$ I.e., of Judah and Israel, whom Eliezer had singled out in his comment on v. 1.

191 This is Eliezer's gloss on the נקבי ראשית הגוים, nequvei reishit ha-goyim, "the notables of the leading nations," mentioned in v. 1.

192 While Eliezer surely did not understand the term מרזח, marzeah, specifically in this way, his citation here of Jeremiah 16:5 indicates his awareness of the connection between the mourning rites alluded to in Jeremiah and the ritual, festive aspect of those rites here in Amos. Earlier rabbinic sources (e.g., BT Moed Qatan 28b; Ketubot 69a), with which Eliezer was likely familiar, also made the connection between those two aspects; see Paul (1991), 211, n. 102 for a fuller list of these sources. For a modern bibliography on the mrzh festival, see Paul (1991), 210-11, nn. 100-1.

193 Eliezer uses the common rabbinic term for the terminally ill, שכיב מרע, shekhiv me-ra', lit. "one who lies down from evil." See, e.g., BT Ketubot 55b; Gittin 9a. 
6:8: By His soul: i.e., by Himself, as in By Myself I swear (Genesis 22:16). Detest: [In Old French]: "Desedsiront," [i.e., "disdain"]. ${ }^{194}$ In other words, it does not carry the meaning of "long for," and thus functions as the opposite of I long for your deliverance, O LORD (Psalms 119:174). ${ }^{195}$ The pride of Jacob and its fortresses: their strength and their strongholds. ${ }^{196}$ I will deliver up the city and its fullness, by the hand of the enemy.

6:9: And it shall be, if there should remain from the sword of the enemy ten men even in one house [they shall die].

\section{6:10: And he shall carry him away, shall his kinsman, and burn (for) him} (incense): (The one who shall perform this rite shall be) the one closest to him, who is responsible for burying him and for burning for him burnings of mixtures and compounds ${ }^{197}$ in (his) honor. ${ }^{198}$ And he shall carry him away... to take out bones from the house: to empty the house and to cast out, as it says later: a multitude of corpses in every place, strewn about (Amos 8:3). At the back of the house: at its end. ${ }^{199}$ Are there yet with

194 Or "detest." See Poznanski (1913), 150, n. 6; Greimas (1992), 164.

195 In other words, the Hebrew verbal root $ב-\aleph-ת, t-a-v$, has the meaning of "long for" in the qal conjugation (as in Psalms 119:174), and "detest" in the pi'el conjugation, here in Amos 6:8. Eliezer warns the reader, in effect, not to confuse the two. The MS seems deficient here, and I have followed the suggested emendation by Poznanski (1913), 150, n. 7. Radak has apparently reproduced Eliezer's comment in his own commentary on the verse.

196 The term ארמון, armon, can also mean "palace," and here Eliezer seems concerned to stress the word's military connotation. Whereas he does not comment on the expression גאון יעקב, ge'on yaaqov, "pride of Jacob," here, he does explain it as "their Temple" in its occurrence in Amos 8:7.

197 Eliezer alludes to the royal mourning rites described in 2 Chronicles 16:14.

198 This is a difficult verse. Although the word "incense" is not present here, I have supplied it in the translation, since that is how Eliezer understands the verse. To translate literally, "to burn him," as if the MT hapox legomenon מסרפו, mesarfo, were equivalent to the verb ש-ר (but which is elsewhere found in the pi'el conjugation as it is here), would suggest a burial rite virtually unattested in Israelite culture. See Paul (1991), 214-16 for this and other explanations. It is typical of Eliezer's independence that he offers a contextual explanation that suggests burial practices so far removed from rabbinic custom.

199 Eliezer wants the reader to know that in this instance, the word ירכתי', yarketei, that can otherwise mean "the innermost part" or "the deepest part" (cf., e.g., Jonah 1:5), instead means "at the rear" of the house. 
you: i.e., in the place where you are, bones, that we may carry them out $?^{200}$ (He shall say), None: All have been destroyed. He shall say "Hush!": Be quiet, and don't cry, lest the enemy sense us, for the city is surrounded by them, for it is not the time to cry out nor even to mention the name of the Lord, and to cry out to him for help, since it is a time of evil, and it is not possible to cancel the decree anymore through weeping in prayer or in crying out. ${ }^{201}$ This is what is meant above therefore shall the prudent man in that time be silent (Amos 5:13) from weeping over his brother and over his kinsman, for he knows that it is a time of evil from the Lord (ibid.), and it is His revenge, ${ }^{202}$ and they shall be of no avail - weeping and crying out. He shall be silent (in Amos 5:13) should be understood as in the context of and Aaron was silent (Leviticus 10:3). ${ }^{203}$ To make mention of the name of the LORD: This is like whereas we, in the name of the LORD our God, will call (Psalms 20:8). The essence of this Scriptural passage comes to say that their corpses will rot, ${ }^{204}$ and they shall not be lamented or buried; like dung on the surface of the ground shall they be (Jeremiah 16:4) - on account of their pleasures with which they pleasured themselves, not being concerned about the fracture of Joseph (Amos 6:6). And so does it say below: a multitude of corpses in every place, strewn about (Amos 8:3): strewn about: Without a burial. Hush: ${ }^{205}$ with no lamenting.

6:11: The great house: The houses of the kings and the princes who oppress. Bits: Fragments, thin and crumbling. Breaches: larger pieces

${ }^{200}$ Eliezer thus fills out an elliptical, two-word question, on the basis of the earlier part of the verse.

201 This atypically long comment of Eliezer seems to speak as much to his contemporary Jewish community as it does to explain the circumstances of the Israelites of Amos' time.

202 So Poznanski reads the MS (1913), 151; Cohen (2012), 129 reads "the revenge of the LORD." The manuscript allows for either reading.

203 Note that Eliezer, in commenting on a word in passing, in a verse that he had ostensibly brought only to explain the text of Amos 6:10 (!), has chosen another context full of pathos and pain, in which Aaron had seen his own sons inexplicably struck down on the celebratory day of priestly investiture.

204 See Isaiah 34:3.

${ }^{205}$ Having just commented on a word ("strewn about") that appears in Amos 8:3, it is not clear if Eliezer is now commenting on the word ה, has ("hush") in Amos 6:10 or in 8:3. In either case, his explanation fits both contexts. 
than the bits. Each one (was destroyed) according to its punishment and its pride. ${ }^{206}$

6:12: Can horses gallop on a rock?: Is it not true that, were they to come to run (on a rock), they will fall and be broken? And should a man plow a rock ${ }^{207}$ with cattle, not even with the strength of an ox (Proverbs 14:4) will he cleave and split it in the ground, ${ }^{208}$ as in plowing. Even so, you will not trample on your enemies, since you have turned justice into poison weed, and the fruit of righteousness to wormwood.

6:13: And you rejoice and adorn yourselves for no purpose: For a thing in which there is naught, and for a victory and valor which they did not accomplish and which did not come from them. For you say, "Have we not by our own strength and our power and the might of our hand $s^{209}$ taken horns for ourselves, with which to gore all the nations, together, to the ends of the earth?!" 210 Whereas it was My hand that did this to them, ${ }^{211}$ and (it was) for the purpose that My name not be desecrated, ${ }^{212}$ and it was not for them (i.e., for Israel), for they have turned justice into poison weed (Amos 6:12). In the same way that the horse by its valor cannot run and trample a rock, nor can an ox by its strength plow it and cleave it, for a

206 As Poznanski $(1913,151$, n. 2) notes, Eliezer essentially paraphrases Rashi’s explanation.

${ }^{207}$ Rabbi Eliezer has astutely sensed the difficulty in the lack of a direct object for the verb "plow," and has cleverly considered the noun "rock" from the first part of the verse ("Can horses gallop on a rock?") as serving a double-duty in the second clause. Additionally, he has supplied a missing subject for that verb, as well ("a man”)! Thus, he suggests reading the prophetic rhetorical question as I have translated: "...And should a man plow a rock with cattle?" Most modern interpreters choose to resolve the problem by emending the word "cattle," literally "oxen," understanding the Hebrew plural ending *ym as masking the Hebrew word for "sea" (yam). Thus, they would render the verse as "Can one plow the sea with oxen?" See RSV and Paul, Amos, 218.

208 See Psalm 141:7.

209 Eliezer adds the warning language of Deuteronomy 8:17 to that of Amos.

210 Eliezer invokes the language of Deuteronomy 33:17, of which doubtless he was reminded by the word קרנים, qarnaim, "horns," that appears there, as well.

211 Eliezer uses the language of Isaiah 41:20.

212 See Ezekiel 20:9. By implicitly presenting the prophetic speech as having ended in 6:12, and by introducing God as the speaker of 6:13, Eliezer deftly anticipates God's speech in the following verse. 
rock will dislocate and break its bones, so, too, will they (the Israelites) not tread on the high places of their enemies ${ }^{213}$ by their strength and valor; rather, their enemies shall break them.

\section{6:14: For behold, I will raise up against you a nation... and they shall} oppress you: And you will have no ability against them. (Scripture has) compared ${ }^{214}$ them to strong and powerful horses and cattle, and their enemies to a rock, stronger than the horse and cattle, for if one (of these) would tread on it, in the end it would be crushed and broken by it. So, too, they - were they to come and tread upon the high places as they had tread in the past, ${ }^{215}$ their enemies would break and crush them, for their protection has departed from them (Numbers 14:9). ${ }^{216}$

\section{Chapter Seven}

7:1: And, behold, he was forming locusts: And, behold, He, the Omnipresent, was creating ${ }^{217}$ locusts $^{218}$ to consume the fruit of the earth. At the beginning of the sprouting of late-sown crops: At the beginning of the growing of the crop of the spring rain, which is in Nisan, ${ }^{219}$ when there were yet three months to the harvest (Amos 4:7). And, behold, the latesown crops: And, behold, the produce from the growth of the spring rain

213 Eliezer alludes to the language of Deuteronomy 33:29.

214 Or, "employed figurative language."

215 Literally, "to this day."

216 Showing a delightful intuition of irony, Eliezer has cleverly cited a verse (Numbers 14:9) which in context was part of a speech meant to persuade the Israelites to overcome their enemies, for "their - i.e., the Canaanites' (!) - protection has departed from them." Yet Eliezer has used that very verse in his comment on Amos 6:14 to illuminate just how vulnerable to their enemies has the Israelites' immoral conduct left them.

217 Since it would appear that God is "creating" these locusts deliberately (and, perhaps, ex nibilo), Eliezer exchanges the verb יוצר, yotzer, used by Amos, with בורא, boreh ("creating," rather than "forming," as though out of previously existing material).

218 There are many words for "locust" in Biblical Hebrew (see Joel 1:4). Here, Eliezer substitutes the more common גברי arbeh, for the comparably rare; the latter occurs only here, in Nahum 3:17 and Nehemiah 11:8.

219 The first month of the year, in spring (see Esther 3:7; also Exodus 12:1ff; Deuteronomy $16: 1 \mathrm{ff})$. 
(was reaped) after they reaped the produce of the king, which are reaped first. The reapings (of the king): (This word) is like: He shall come down like rain upon the reaped-grass (Psalm 72:6). For proximate to the time of the spring rain, which is in Nisan, they shear the leaves from the produce, that it may grow on a stalk or an ear, when the rain falls.

7:2: When it was to have ceased consuming: And for this purpose was it being created. And, knowing this, when it was to have ceased consuming means that it was going to cease consuming, ${ }^{220}$ without any survivor. And when I had heard this, I said: ah, Lord God: if thus shall you do, who will yet ${ }^{221}$ arise in Jacob, for even now is it small and greatly downtrodden. ${ }^{222}$

\section{7:3: The LORD relented concerning this: His tenderness was stirred ${ }^{223}$ when I said this.}

${ }^{220}$ I have translated the biblical phrase והיה אם כלה, ve-hayah im killah, as a future perfect, as that is how Eliezer understands it: when the plague of locusts "was to have ceased consuming" (see also Genesis 24:19, 22). Contrast most English translations: "When it had finished devouring" (NJPS); "When they had finished eating" (RSV); "And it came to pass, that when they had made an end of eating" (KJV); Rashi, likewise, considered the vision as already complete (כ אשר כלה לאכול, ka-asher killah leekhol, "when it had finished consuming").

${ }^{221}$ In adding the word עוד, 'od ("yet"), Eliezer may be influenced by God's decree in 7:8 and 8:2 לא אוסיף עוד עבור לו, lo osif' od avor lo, "I will no longer continue to pass by him").

222 In grasping the correct sense of the verb הלכ, Eliezer's interpretation seems in line with the astute observation of his predecessor, R. Yosef Kara. The latter not only understands the verb properly, but also articulates the intercessory function of the Israelite prophet:

כשראיתי אותו שבא לכלות ולאכול כל עשב הארץ, מיד עמדתי לבקש מאת הקדוש ברוך היוך הוא לסלוח על אותו

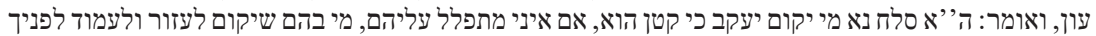

להפגיע שתבטל בשבילו הגזרה זו כי נתמעטו צדיקי הכואי המאור

"When I saw that (the plague) would completely consume all the vegetation of the earth, immediately I arose to request from the Holy One, Blessed be God, to relent concerning this sin, and I said: Lord God, relent, I pray, how can Jacob arise, since he is so small! If I do not pray for them, who among them will arise to help (them) and stand before you to entreat that you cancel the decree on their behalf, since there are so few righteous people in this generation." On prophetic intercession, again see Yochanan Muffs, "Who Will Stand in the Breach?," 9-48. On understanding the passage as portraying God relenting regarding the punishment, but not completely pardoning the Israelites, see Paul (1991), 230.

223 Eliezer substitutes a different biblical idiom than the one Amos employs; see 
7:4: Summoning to contend by fire: i.e,. for a judgment with them, in great anger. Was eating up a portion: A portion of their land.

7:7:224 A wall (measured by) a plumb line: ${ }^{225} \mathbf{A}$ wall aligned and measured. ${ }^{226}$ And in his hand is the line with which to measure.

7:8: Behold, I am setting a plumb line: A line and a measure with which to straighten every distortion of justice. I will no longer continue to pass by him for his crimes, but rather will (incline) after the attribute of (strict) justice. ${ }^{227}$

7:9: House of Jeroboam: son of Joash.228

7:10: Within the House of Israel: Who are at peace with you.

Hosea 11:8, where this prophetic contemporary of Amos uses the expression that Eliezer prefers, "I have had a change of heart, All My tenderness is stirred." Perhaps Eliezer sees in the Divine response to this prophetic intercession a moment of greater pathos than the biblical verb typically employed when God changes His mind נחם, $n-h-m$, in the nif'al conjugation, as Amos states here). On Divine pathos, see Abraham Joshua Heschel, The Prophets (New York: Harper \& Row, 1962); in particular, see 51-52, where Heschel contrasts Amos and Hosea's capacity for sensing Divine pathos.

${ }^{224}$ Note that Eliezer does not apparently feel the need to explain vv. 5-6, as he had already virtually interpreted them in his commentary on vv. 2-3.

225 I have given the translation of "plumb line" for Hebrew anakh, since it is found in the translations and is also somewhat in fitting with Eliezer's explanation. However, there is no longer any question that the word should not be so translated; it is now known for certain that it is an Akkadian loanword meaning "tin"; see Paul (1991), 233-34, and nn. 63-64 there, for the bibliography. It should be admitted, however, even the clarification of that word does not resolve the difficulty of the passage. As Shalom Paul has written, "The probability still very likely exists that there is more in this vision...than meets the eye, and thus it is no wonder that the prophet, as well as his exegetes, remains baffled by its symbolism"; see Paul (1991), 235.

226 Eliezer may be thinking of such verses as 2 Kings 21:13 and Isaiah 28:17.

${ }^{227}$ It is a staple of rabbinic Judaism that God may be depicted as if occasionally in conflict between his attributes of justice and mercy. See, e.g., Genesis Rabba 12:15 (alluded to in Rashi's comment on Genesis 1:1). For a brief discussion, see Lou H. Silberman, "Justice and Mercy of God," in Encyclopedia Judaica (Cecil Roth, ed. Jerusalem: Keter Publishing House, Ltd., 1971), VII: 669-70.

228 Eliezer adds the genealogy so that the reader will not confuse Jeroboam II (2 Kings 14:23-29) with Jeroboam I (1 Kings 11:26-40; 1 Kings 12:20, etc.). 
7:12: To the land of Judah: Since prophets like you are accepted there.

7:13: For it is a sanctuary of the king: And angry men will attack you ${ }^{229}$ on account of your words.

7:14: Neither a prophet am I: I am not practiced in prophecy, but now, recently, the Lord has taken me from following the flock. ${ }^{230}$ Nor the son of a prophet am I, that they should say, "Thus did his father, and the custom of his father he is grasping." A cattleman: a herder of cattle. A dweller (among the sycamore trees): Its explanation is according to its context: ${ }^{231}$ Dwells and crouches in the shade of sycamores for the purposes of grazing. ${ }^{232}$

7:17: In the city shall she play the harlot, in the manner of adulterers, going outside in the desolate areas, a place where no people are found therein. But with her (this shall happen) in the city - in a place where (normally) were she to have cried out, she would have found a rescuer ${ }^{233}$ - shall she play the harlot. By a (measuring) rope shall it be divided up among foreigners, and not among your sons. On soil impure (shall you die), and not in the land of your birth.

${ }^{229}$ It seems that Eliezer is deliberately invoking the language of Judges 18:25.

${ }^{230}$ Eliezer is anticipating and adapting the language of Amos 7:15.

231 This is a favorite formula of the northern French rabbinic exegetes for treating particularly difficult texts, such as this one. See Harris (1997), 280-300. Here, it is invoked because there appears to be no other strategy for understanding the hapox legomenon, (שקמים) boles (shiqmim); I have rendered it "A dweller (among the sycamore trees)" in keeping with Eliezer's interpretation.

232 Thus Eliezer interprets the difficult בולס, bo-les, within the "professional" context of the more easily interpreted בוקר, boqer, "cattleman."

${ }^{233}$ See Deuteronomy 22:27. 


\section{Chapter Eight}

8:1: A container: A vessel. ${ }^{234}$ Summer: Fruit that is ripened, and (then) dried.

8:2: The end has come: i.e., the absolute (end). ${ }^{235}$

8:3: The songs of the palace that they sing in their palaces of pleasure (Isaiah 13:22). Strewn about; hush!: This is as I have explained above. ${ }^{236}$

8:4: Who trample the needy: They drag away and trample his wealth and possessions. To make cease: To make cease ${ }^{237}$ from being among them, the poor of the land, causing them to dwell alone in the midst of the land. ${ }^{238}$

8:5: The New Moon... and the Sabbath: In all places (Scripture) has placed $^{239}$ "new moon" and "sabbath" together, since they were for them days free from work, as in the following cases: It is neither new moon nor sabbath (2 Kings 4:23); ${ }^{240}$ on the sabbath it shall be opened, and in the day

234 Other than here in Amos 8:1-2, where it is not clear, the word כלוב, keluv, only appears in Jeremiah 5:27 ("As a cage [כלוב] is full of birds, So their houses are full of guile"). Eliezer offers a general explanation, as the exact nature of the "container" is not contextually available. For modern scholarship, see Paul (1991), 253.

235 I.e., the hour of Israel's doom, as opposed to simply the end of the summer growing season. While none of the medieval commentators directly addresses the wordplay between "summer" (pr, qayitz) and "end" ( $p$ p, qetz), Kara and Radak do note some connection between the two words.

236 See Eliezer's commentary on Amos 6:10.

237 Since the MT gives a contracted form of the verb "to make cease" (לשבית, lashbit), Eliezer repeats it in his gloss, but gives the fuller form (להשבית, le-hashbit) instead. All of the standard rabbinic commentators (Rashi, R. Yosef Kara, R. Avraham ibn Ezra, Radak) do the same.

238 Eliezer alludes to the prophetic speech of Isaiah 5:8.

${ }^{239}$ Literally, "he has seized" (תפ, tafas). See above, on 2:7.

${ }^{240}$ Eliezer actually erred in his citation of Scripture here, writing, "It is neither new moon nor sabbath today." As Poznanski (1913) notes, 152, n. 5, Eliezer was likely influenced by the preceding sentence within 2 Kings 4:23: Why are you going to him today? He (or the copyist) similarly misquotes Scripture in the following two prooftexts (Ezekiel 46:1 and Isaiah 66:23). The medievals largely cited biblical texts from memory, which was occasionally faulty. See Edward L. Greenstein, "Misquotation of Scripture in the Dead Sea Scrolls," in The Frank Talmage Memorial Volume (Barry Walfish, ed. 
of the new moon it shall be opened (Ezekiel 46:1); From new moon to new moon, and from sabbath to sabbath (Isaiah 66:23); and likewise there are many others. When will the new moon be over... and the sabbath: Since there are not on those (days) markets, and it was a burden to them. So that we could sell grain...using an ephah that is too small, and a shekel that is too big, to sell at a lesser rate and with a heavier and greater weight. And the measurements and the weights and the estimations would change the day following the new moons and the sabbaths.

8:6: To buy, with silver, the poor: (To make them) slaves, and to take their possessions at a cheap price. In order to lock them up: (The prophet employs this rhetoric) since they were locked and closed from such oppression and hunger, ${ }^{241}$ and they would not pardon them, to lend them sufficient for their need. ${ }^{242}$ And refuse of grain: The inferior produce of their homes we will sell to them, as in: I am not inferior to you (Job 12:3). All excellent produce (Scripture) calls "grain." 243

8:7: The Pride of Jacob: This is their Temple.

8:8: It shall arise like the Nile: Like the Nile. ${ }^{244}$ It shall be tossed up: (Become) mire and mud. ${ }^{245}$ It shall sink: It shall become like sunken mud that is not suitable for walking on. Like the Nile of Egypt: That rises and inundates its surroundings.

Haifa: Haifa University Press, 1993), I: 71-83 (for misquotation among medieval exegetes in particular, see 71-74).

${ }^{241}$ See above, on 2:6. Again, Eliezer does not take the biblical phrase to refer to "a pair of sandals."

242 Eliezer has adapted the language of Deuteronomy 15:8.

243 Eliezer is trying to make a distinction between Amos' use of the rare term (mapal bar, literally "the fallen away of the grain"; here translated as "the refuse of the grain") and the word שבר, shever, often used elsewhere in Scripture to refer to desirable grain (e.g., Genesis 42:1-2).

${ }^{244}$ To avoid the possibility that the reader will understand the MT כאור, keor, as "like the light" (see the end of 8:9), Eliezer follows Rashi in replacing the MT text with the conventional spelling for "Nile," כיאור, keyeor; see 9:5 and the end of 8:8. On כאור, keor, as a likely copyist's error, see Paul (1991), 260, n. 48.

${ }^{245}$ Eliezer alludes to Isaiah 57:20. 
8:9: I shall bring (down) the sun to them, in other words, a day of darkness shall there be for them.

8:10: Your celebrations: That you celebrate in delight and joy. And the end of it like a bitter day: In other words, that even in its end they will not be able to be comforted, for it shall always be to you a new moon at its beginning. ${ }^{246}$

8:11-12: But for hearing the words of the LORD: For successive troubles will so greatly multiply that they shall run to and fro to seek...the word of the LORD to know what shall be their end, ${ }^{247}$ if it will be so forever.

8:13: They shall faint: A strong enveloping of wind $^{248}$ and strong breath, from an abundance of anguishing of spirit.

\section{Chapter Nine}

9:1: Strike the capital: Every protrusion of a vessel (Scripture) calls a capital, as (is the case with) the capitals of the menorah which protrude on a branch underneath two branches. ${ }^{249}$ Even this (capital) protrudes at the doorpost, towards the bottom, underneath the thresholds, like those that are called (in Old French) "piliers" [i.e., "pillar"], ${ }^{250}$ a type of sockets on posts. And therefore (God) says to the angel, ${ }^{251}$ Strike the capital that is

246 The new moon is seen only as a sliver, thus conveying a lowly fortune; a full moon is understood as ripe and bounteous. The Sages saw the waxing and waning of the moon as indicative of Israel's fate throughout the generations; see BT Sanhedrin $42 \mathrm{a}$, which contains the rabbinic blessing to be recited on the occasion of seeing a new moon: "To the moon, God ordained that it should be renewed as a crown of beauty for those whom He sustains from the womb (see Isaiah 46:3) and who will, like it, be renewed in the future."

247 See Deuteronomy 32:20.

248 See Psalms 77:4.

249 See Exodus 25:35; 37:19-21.

250 Poznanski (1913), 153, n. 3; Greimas (1992), 457.

251 Eliezer is apparently reacting to the difference between this vision $(9: 1-6)$ and previous ones $(7: 1-3 ; 7: 4-6 ; 7: 7-9 ; 8: 1-3)$, which contain a dialogue between God and Amos. Here in chapter 9, Amos sees a vision of the Lord, and the Lord speaks, but 
underneath the thresholds, so that the thresholds quake that are above it. And finish them off: And the tumult and the striking shall put an end to them, from bottom to top, in their full lengths. For from striking the capitals, all of the thresholds shall quake throughout their lengths. Thus the striking and the trembling will begin from the foundations of the people, their kings and princes, as it says above: Therefore they shall now be the first of those to go into exile (Amos 6:7). And the last of them: I.e., those that remain. By the sword will I slay them, as it says above: And it shall come to pass, if there remain ten men [in one house, that they shall die] (Amos 6:9). And the striking shall finish with the rest of the people who are dependent on them, upon the heads of the thresholds who are dependent on the capitals.

9:2: If they dig down: This is the language of digging deeply. ${ }^{252}$ Moreover, the steering by oars - since it is in the depths of the water in secrecy, ${ }^{253}$ as is the way of those who dig under a house - is called "digging," as in: the men rowed to return to land (Jonah 1:13)..$^{254}$

9:3: If they hide: In the cover of the forest and the trees. At the bottom of the sea: At its foundation. (I will command) the serpent: Which dwells in the pits of the earth. ${ }^{255}$

9:4: And even if they go into captivity before their enemies, they shall not be saved by this, from the sword.

9:5: And behold, the Lord, GOD of hosts, he who touches the earth and it melts: And therefore, if they dig down to Sheol (Amos 9:2), it shall

Amos does not respond. Therefore, Eliezer deduces that, if the Lord was speaking, it must have been to an attending angel.

252 See Exodus 22:1; Jeremiah 2:34.

253 I.e., since the oars do their work under water, where they are not "seen."

254 Thus, Eliezer demonstrates that the same Hebrew verb (לחתור, lahtor) is used both for "digging" and for "rowing."

255 Eliezer's contextual interpretation stands in marked contrast to Rashi, who relies on the Targum's muting of the mythological allusions of the verse: אפקיד ית עממיא דתקיפין כחויא ויקטלונונון , "I will command the peoples who shall seize (them) like a serpent and shall kill them.” See Paul (1991), pp. 278-79. 
vomit them up from there and shall not shelter them, on account of all who dwell in it, even if they are at the bottommost of the earth.

9:6: And if to the top of Carmel they ascend and hide, ${ }^{256}$ behold He builds in the heavens, at a great height, as in: cities that are great and fortified in the heavens (Deuteronomy 1:28). His steps: ${ }^{257}$ To ascend on them to the top of Carmel, to search them out and take them. And his vault - the connecting-together of the wall and the group of buildings and its foundations - on the earth did he found it. The language of "connectingtogether" is appropriately applied to "building," as in: and all the wall was joined together to its half (Nehemiah 3:38). And if on the bottom of the sea they would hide, behold He calls for the waters of the sea, and pours them out upon the surface of the earth. And the foundations of the sea would be revealed, and its bottom, and they would not be able to hide from me. None of these things are actually so, but are (only) as if. ${ }^{258} \mathbf{H e}$ builds in the heavens his vault to ascend and to search for them, and as if the waters of the sea are poured out from its inside to uncover its foundations and I will see them, and the serpent shall come and bite them. And know that you will not find a serpent in the sea, nor a crocodile on dryland. ${ }^{259}$ And as for (Scripture) saying He will slay the crocodile that is in the sea (Isaiah 27:1), this is referring to a crocodile alone, and not on either an

256 Eliezer rephrases Amos 9:3.

257 I have rendered in this way since that is how Eliezer understands it. For Biblical Hebrew מעלותיו, ma'alotav, meaning "steps," which is its usual meaning, see Exodus 20:23; 1 Kings 10:19-20, etc. Modern translations (NJPS, RSV, KJV) render “(upper) chambers," in effect relying on an emended text (עליותיו, aliyotav); see Paul (1991), 280, n. 75.

258 By this formulation ("None of these things are actually so, but are only as if"), Eliezer is demonstrating that peshat (contextual) methodology is not necessarily "literal," but may in fact be figurative. His teacher, Rashbam, had demonstrated this in a celebrated comment on Exodus 13:9 "It shall be for you for a sign on your hand and for a reminder between your eyes"). Recognizing that the verse did not refer to a concrete ritual such as the tefillen ("phylacteries") the ancient rabbis had intuited should be worn at prayer, but was metaphorical in nature, Rashbam had commented: "For a sign on your hand according to the depths of its contextual meaning [peshuto], it should be for you as a continuous memorial, as if it were written on your hand. This usage is similar to place me as a seal upon your heart (Song of Songs 8:6)." Like other northern French exegetes, Eliezer frequently employs the verb (דימה, dimmah, "compares") on which he typically relies to indicate the metaphorical nature of a contextual interpretation (e.g., on Isaiah 27:1).

259 See Nevo (1986), 1-5. 
elusive serpent... (or) a twisted serpent (Ibid.), for these are on dry-land, and it is on dry-land that (God) will punish them (Ibid.).

9:7: Are you not like the Ethiopians to me: And therefore on what are you placing your trust? Is it not the case that when you sin against me you are nothing more to me than like the Ethiopians, who are the least among nations, so I will neither pity nor have mercy upon you (Jeremiah 13:14), and I will dispossess you from the land, and it shall vomit you out. ${ }^{260}$ For if for the purpose of dispossessing other nations, greater and more powerful than you, ${ }^{261}$ whereas you are of the opinion that you will possess it forever, Did I not bring up Israel from the land of Egypt to inherit this land, also the Philistines did I bring up from Caphtor, to inherit the land of the Avvim ${ }^{262}$ - and even nevertheless I will wipe out the inhabitants from Ashdod, and from Gaza, from Ekron and from all of (the lands of) Philistines. ${ }^{263}$ And also Aram I brought up from Kir, to inherit the land of the East, nevertheless so will I cut off inhabitants from Damascus and from Eden and from the Valley of Bet Aven and they shall be exiled with Aram towards $\mathrm{Kir}^{264}$ - also you will I exile from the land that I gave you! For not on account of your righteousness and the straightness of your heart do you dwell in it, but rather on account of the wickedness of those nations that dwelled in it. ${ }^{265}$

9:8: For behold, the eyes of the Lord GOD are upon the sinful kingdom to destroy $\mathrm{it}^{266}$ from off the face of the ground upon which it dwells. And so will God do to you, for He does not favor any man. ${ }^{267} \mathrm{But}, \mathrm{He}^{268}$ will

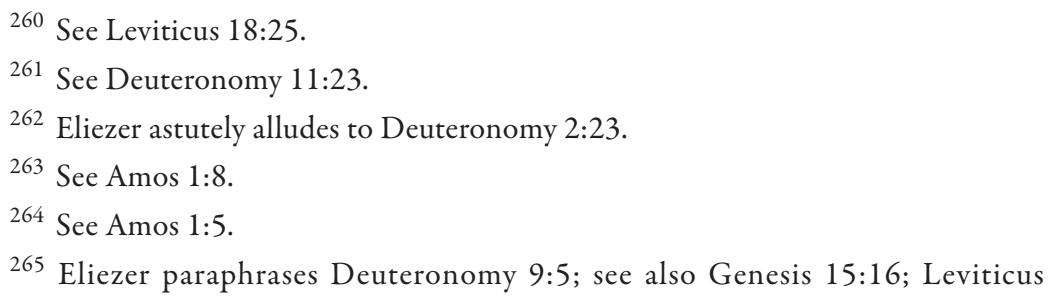

266 Eliezer has altered the Hebrew text from a finite verb ("I will destroy it") to an infinitive.

267 See Deuteronomy 10:17.

268 Eliezer has changed the first-person Hebrew prophecy into the third-person, and has altered the infinitive absolute verbal construction (השמד אשמיד, hashmed ashmid) into a simple indicative (ישמיד, yashmid). 
not...destroy the House of Jacob, as He had destroyed the Amorite, ${ }^{269}$ in cutting off his remembrance, ${ }^{270}$ but (God's purpose is) to annihilate you from off...this ground and to exile you to another land. ${ }^{271}$

9:9: Rather, ${ }^{272}$ I will command, and shake the house of Israel among all the nations as one shakes grain with a sieve: For the grain goes out and the pebbles remain in it. The notables among the people, and the princes and mighty ones will be shaken among the nations, and the lessor ones and the poor of the people shall remain. ${ }^{273}$

9:10: (Evil) shall not approach, (i.e.), shall not draw near, nor shall it advance in our days, (shall) the evil. ${ }^{274}$ Upon us: On account of our deeds.

9:11: And then, on that day, when all the sinners of My people (Amos 9:8) shall cease, I will raise up the booth of David that is fallen, since it is the way of the shepherd to make for himself a booth to give rest to his flock, ${ }^{275}$ and to sit in the shade to watch his flock, and (since) David was the shepherd of Israel, ${ }^{276}$ the prophet has likened Jerusalem and his dynastic house to a shepherd's booth.

269 See Amos 2:9.

270 See Psalms 34:17.

271 See Deuteronomy 29:27.

272 Eliezer has correctly glossed MT כי הנה אנכי מצוה, ki hineh anokhi metzaveh ("For lo, I will command") by replacing it with אלא הנה אנכי מצוה מנד , ella hineh anokhi metzaveh ("rather, I will command"), reading "rather than totally destroying the people (as seemed apparent by 9:8a), I will only eradicate the sinners" (v. 10). Thus, Eliezer understands that the force of 9:9ff is to mitigate the absolute nature of the condemnation with a somewhat consoling message. The Rabbis had taught that the word in Biblical Hebrew can convey (at least) four meanings; see, e.g., BT Rosh Hashanah 3a; Gittin 90a. Eliezer was presumably acquainted with this knowledge either through these rabbinic texts, or by Rashi referring to it in his commentary on Genesis 18:15.

273 See 2 Kings 24:14.

${ }^{274}$ In order to explain the verse, Eliezer has paraphrased the MT and rearranged its word-order.

275 See Jeremiah 33:12.

276 See 2 Samuel 5:2. 
9:12: So that they shall possess: And by this they shall possess the remnant of Edom, which is next to them, and the rest of the nations, since it shall be that they shall be called by my name.

9:13: The plowman shall meet the reaper: In one field there shall be plowmen for the purpose of sowing, and reapers, together. So much shall the produce of the year be great, that until the time of the plowing in Marheshvan, ${ }^{277}$ they shall (still) be reaping. And this is greater than the blessing of Moses, when he said: Your threshing shall overtake the vintage (Leviticus 26:5), that at the time of threshing, the harvest will have already ended, and even the threshing that is later than the harvest shall not approach the plowing for seed, rather the grape-gathering which is before the seeding. And the treader of grapes (shall meet) him who pulls the bag of seed: He pulls it over the furrow, as he turns over his sowing, as in carrying the seed-bag (Psalms 126:6). Sweet-wine: Sweetness. ${ }^{278}$ Shall melt: As if the ground shall melt from the multitude of honey and the milk of the abundance of fruit.

277 The name of the month in the late fall (October-November).

278 Eliezer uses a more common biblical Hebrew word to define the less common word Amos employs. 



\section{The Commentary of Rabbi Eliezer of Beaugency on Jonah}

\section{Chapter One}

1:2: That large city: This is the reason for which Jonah fled, since God said to him, "It is a large city," and (so Jonah reasoned), "it is impossible that all of the inhabitants will repent. Moreover, the LORD is merciful and compassionate ${ }^{1}$ and he won't destroy such a large city." And cry against it: in my name, ${ }^{2}$ since their great wickedness has arisen and grown strong in my presence, and it is now my desire to destroy them.

\section{1:3: And Jonah arose to flee towards Tarshish from the service ${ }^{3}$ of the}

LORD: he wanted to slip away from God, that God "should send whomsoever he would send," ${ }^{4}$ since Jonah was an old and weak man, ${ }^{5}$ and if

${ }^{1}$ See Exodus 34:6; Jonah 4:2; Eliezer paraphrases here slightly.

2 Literally, "from me" (מאתי, me-iti).

3 That this is Eliezer's understanding of the phrase is apparent from the end of his comment on 1:10, similar to the translation of the NJPS; see Uriel Simon, The JPS Bible Commentary: Jonah (Philadelphia: The Jewish Publication Society, 1999), 6. Contrast Jack M. Sasson, Jonah. Anchor Bible (New York: Doubleday and Company, Inc., 1990), 66, who offers "Jonah, instead, sought to escape the Lord," and see his long note, 78. RSV, KJV: "Jonah rose to flee...from the presence of the LORD."

${ }^{4}$ See Exodus 4:13. Thus, Eliezer compares the experience of one reluctant prophet - Moses - with another. For a portrayal of contrasts between Jonah and Moses, see Simon, Jonah (1999), xxxvii.

5 There does not appear to be a midrashic source or exegetical parallel for Eliezer's interpretation, and it does not appear to be based on information provided by the Biblical text. It seems to me that Eliezer infers Jonah's age and condition from his understanding, expressed later in his commentary as well, that one of the reasons for Jonah's reluctance to prophecy as God wished was that - knowing that God would not punish the Ninevites - he, being so old and weak, didn't want to undertake the mission in vain. Contrast the midrashic tradition (Pirke De R., Eliezer 9): “Why did [Jonah] flee? ...[God] sent him to Jerusalem to [prophesy] its destruction. God acted according to 
he would go, since Tarshish was a large city and the inhabitants wouldn't repent, and God is merciful and will renounce punishment, ${ }^{6}$ even though they still be sinners, it would turn out that he would weary himself ${ }^{7}$ on this long journey for nothing. For (Jonah reasoned) they would not repent, and the Omnipresent ${ }^{8}$ would not wreak judgment upon them by Jonah's hand. But as for refusing outright and saying "I will not go," Jonah did not want to rebel against God's word. Instead, he arranged to slip away, as if to say: "Send whomsoever you will send."

He went down to Jaffa: in the area of the port and the harbor.

1:4: On the sea: in the very spot where the ship was. ${ }^{10}$ Therefore everyone recognized that it was not only a coincidence for them, since all of the other ships sailed on calm seas, whereas this one was in a storm. ${ }^{11}$

His great mercy, pardoned the evil and did not destroy it. Therefore [the Jerusalemites] called [Jonah] a false prophet... [God] sent him to Nineveh to [prophesy] its destruction. Jonah reasoned, 'I know that the gentiles are close to repenting - now they will repent and God will turn his wrath against Israel. Moreover, it's bad enough that Israel calls me a false prophet, but do the gentile nations have to as well?!" Ginzberg sanitizes the midrash in his rendering; see Louis Ginzberg, The Legends of the Jews (Henrietta Szold, trans.; Philadelphia: The Jewish Publication Society, 1913), vol. IV, 247, and vol. VI, 349, n. 27.

${ }^{6}$ Eliezer paraphrases the language of Jonah 4:2.

7 Literally, "break his body."

${ }^{8}$ Hebrew המקום, ha-maqom, literally "the Place," a common rabbinic name for God.

${ }^{9}$ Here, in addition to Jonah's skepticism (which Eliezer already observed) that God, being merciful, would not destroy such a large city, Eliezer points to two other factors influencing Jonah's flight and refusal to prophesy. The first, intimated by Eliezer in his paraphrase of Exodus 4:13, is to see Jonah as one of a long line of "reluctant biblical prophets" that began with Moses: the response that Eliezer places in Jonah's mouth ('send whomsoever you will send') is a clear reference to Moses' initial refusal of God's proffered mission. However, Eliezer also claims that Jonah's age and physical infirmity are factors: for such an old and weak man to walk to Nineveh - certain as he is that the prophetic call will go unheeded and that God will in any event not act on it - is just too much to expect.

${ }^{10}$ God "threw the storm at the sea."

${ }^{11}$ This is according to the midrashic tradition; see Ginzberg, Legends, vol. IV, 247 vol. VI, 349, n. 28. It is very surprising to find this reliance upon midrash in Eliezer's commentary, for he generally eschews the rabbinic tradition and interprets contextually. 
And the ship thought ${ }^{12}$ it would be broken up: i.e., (it was thought) by the owners of the ship..$^{13}$

1:5: The sailors: the ones who guide the ship. (They are called thus) since they mix and blend the sea with oars, as in the heavens like smoke have been blended (Isaiah 51:6), i.e., mix and blend. ${ }^{14}$

And they cast off: so that it was lost. This is similar to: why are they cast off, he and his seed? (Jeremiah 22:28).

And he fell asleep: from great trouble, closing-up of the heart and heaviness. ${ }^{15}$

1:6: What is it to you, that you are (sleeping?) $)^{16}$

(Perhaps the god) will decide in our favor: ${ }^{17}$ Will decide, as in: his decisions (come to nothing) (Psalms 146:4).

To us: Concerning us.

12 The Hebrew verb (חשב, hishev, in the pi'el conjugation) has been variously rendered: "the ships was in danger of breaking up" (NJPS); "the ship threatened to break up" (RSV). Simon (1999), 8, notes that "the metaphoric language attributes consciousness to the ship in the common sense of intention and planning." Eliezer's gloss notes the literal difficulty of an inanimate object having "intent," and so transfers the intent to the people onboard (see the following note).

13 Heb. בעלי האניה, baalei ha-oniyah; it is likely that Eliezer means "the ones on board the ship."

${ }^{14}$ Eliezer thus connects the Hebrew word for sailors (מלחים, malahim) with the verb "to dissipate"; see BDB, 571-72. Poznanski, Eliezer of Beaugency, 157, n. 5, refers to Rashi's (first) comment on Isaiah 51:6 as a precedent to Eliezer's interpretation.

${ }^{15}$ Eliezer notes that Jonah's sleep is not due merely to physical exhaustion, but is rather a result of his emotional/spiritual flight from God.

${ }^{16}$ Idiomatically, we understand the sentence to mean, Why are you sleeping?! However, as Eliezer's comment makes clear, he thought the Hebrew syntax required elaboration to make the sense clear.

17 Contrast other translations: NJPS: "will be kind to us;" NRSV: "will spare us a thought;" WBC: "will consider us." 
1:7: On (account of) whom: On account of whose business. [In Old French]: "Par de qui offaire?" ["On account of whose affair"]. ${ }^{18}$

1:8: On whose account has this evil befallen us?: How are we to know that it is on account of you that this evil has befallen us? Tell us please, what is your occupation? Concerning what business of yours did this happen to us? Perhaps you are a thief or a swindler ( $^{19}$ Or you have received a task and its obligations from heaven, and you have abandoned it?

And from where have you come?: Perhaps you are fleeing from matters of murder and rebellions, or you are coming directly from having committed a murder?

What is your land and from what people do you come?: Perhaps you come from an evil and sinful land, or from an evil and sinful people, and the Omnipresent hates you ${ }^{20}$

1:9: I am a Hebrew: He answered them with regard to his land and his people.

The LORD, God of heaven do I revere: I have no obligation or assignment other than to His duty and office; in this, he responded to their question about occupation. ${ }^{21}$ With regard to from where have you come (v. 8) he answered them from the service of the LORD did he flee (v. 10), that he was slipping away so that God would send someone else, as he explains in the following verse.

18 See Poznanski, Eliezer of Beaugency, 157, n. 7.

${ }^{19}$ Heb. קוביוסטים, qobiusyis. This is a Greek loan word in rabbinic Hebrew, found often enough in Talmudic literature for Eliezer to be familiar with it. On the phrase "you are a thief and a swindler," see BT Hullin 91b; Bekhorot 5a.

${ }^{20}$ In understanding what may be the rather more neutral question of the gentile captain with the perjorative and suspiciously-oriented gloss he offers, we may hear an echo of what Eliezer perceived to be a typically Christian, anti-Jewish sentiment. See the following two notes.

${ }^{21}$ If I am correct in suspecting that Eliezer may have cast the captain's questions in negative terms, then perhaps here we see Eliezer's Jewish statement of purpose, as if to say: "You gentiles may think we Jews are wicked, but our purpose is only to serve God." 
1:10: And the men became deeply reverent: When they recognized that he was a man of God, from a holy land and from a holy people, ${ }^{22}$ they did not know what to do to him.

What have you done?: i.e., that you would flee from God's service.

For he had told them: i.e., already, in response to their question from where have you come. ${ }^{23}$ However, the redactor has delayed relating this detail until relating their question what have you done? And there are many examples of this in Scripture. ${ }^{24}$

1:11: What must we do to you?: You yourself should tell us in what way the Omnipresent will be expiated ${ }^{25}$ and how he will be appeased.

${ }^{22}$ Compare the strikingly similar — and sympathetic! - terminology in the commentary of Andrew of St. Victor (and that he took from Jerome): "Timent autem timore magno, quia intelligunt sanctum et sancte gentis virum," "They are exceedingly afraid, because they knew him to be a holy man, a man of a holy people." See Frans van Liere and Mark Zier, Andreas: Expositionem Svper Dvodecim Prophetas (Turnhout: Brepols, 2007), 172, lines 127-28. I presented this text in Robert A. Harris, "Contextual Reading: Rabbi Eliezer of Beaugency's Commentary on Jonah," in Bringing the Hidden to Light: Studies in Honor of Stephen A. Geller (2007), 98.

${ }^{23}$ See the commentary to verse 9.

24 That this comment demonstrates Eliezer's understanding of analepsis as a narrative technique is clearly seen by Meir Weiss, Scriptures in Their Own Light: Collected Essays [Hebrew] (Jerusalem: Bialik Institute, 1987), 315, who finds in Eliezer's comment on Isaiah 20:2 an additional example of the commentator's awareness of narrative analepsis. Weiss also apparently considers Jerome's comment on Jonah 1:10 to be the only exegetical precedent to Eliezer's. However, Eliezer's contemporary, Andrew of St. Victor, is equally aware of it, for he paraphrases Jerome's comment: "Historie ordo preposterus est. Quia enim poterat dici nulla causa timoris fuit, ex eo quod eis confessus est propheta, dicens: 'Hebreus sum etc.', statim subnectitur quod iccirco timuerint, quia indicauerat eis se domini fugere conspectum et eius non fecisse preceptum," "The order of the narrative is reversed, because it could have indeed been said there was no cause for fear, insofar as he had confessed to them: I am a Hebrew and I fear Lord God, who made seas and dry land. Immediately he was bound, since they were on that account afraid, because he had declared to them that he fled the sight of the Lord, and had not kept His precepts"; the Latin text is found in Van Liere and Ziere (2007), 172, lines 120-24; my translation is taken from: Harris (2007), 79-101 (97, see note 63). See also Harris (2009), 321-22; and Harris (1997), 186-90.

25 I.e., "through what means will God grant our atonement." 
1:12: [That the sea] may be silent: that it may be tranquil, as in They rejoiced when all was quiet [and He brought them to the port they desired] (Psalms 107:30). And you will not find this expression in Scripture except in regard to the quieting of a storm at sea.

1:13: For the sea was becoming progressively more stormy: More and more. ${ }^{26}$

[The men] rowed: ${ }^{27}$ this direction and that, in order to reach shore to return him to dry land, so that he would not go with them, and that he would not flee from the presence of the LORD, for in this way they thought that they would correct the offense of his fleeing, and [in doing so] the Omnipresent would be appeased in regard to them.

Around them: (Here, the preposition means) opposing them, and turning them backward. ${ }^{28}$

1:14: And when they saw that they had no choice other than throwing him into the sea, as he had suggested to them, then they cried out to the LORD: (Do not let us perish) on account of this man's life: I.e. if we throw him into the sea as he himself has said to us.

For (it is) you, O LORD - who does this ${ }^{29}$ - as you have willed, so have you done: it is your will and your doing if we throw him in! And it is not on our own that we are doing this, for since we want to return him to dry land, but are unable to do so, and he is telling us that in this way ${ }^{30}$ will the sea be quiet for us; if we throw him in, we know that this is from you and he does not say this from his own heart, and therefore do not punish us on his account.

${ }^{26}$ I.e., the Hebrew הולך וסוער, holekh ve-so'er, lit. "it goes and it storms," is an idiomatic expression that means "it grows more and more stormy."

${ }^{27}$ Note the inverted word order in Eliezer's exposition of the verse: he first treats the issue of the raging sea, and only then (logically) addresses the sailors' determination to reach shore.

${ }^{28}$ I.e., the Hebrew preposition על על 'al, usually but not exclusively understood as meaning "on," here carries the meaning "around (them)."

${ }^{29}$ Here Eliezer adds his comments directly into the Biblical discourse.

${ }^{30}$ I.e., if we throw him into the sea. 
1:15: And the sea stopped its raging: As he said to them. And then -

1:16: The men feared a great fear of the LORD: (They reasoned): if (God) was sanctified through his servant and his prophet, how much the more so (would he be sanctified) through others. ${ }^{31}$

\section{Chapter Two}

2:1: (The LORD) provided: He summoned (the big fish) immediately, so (Jonah) wouldn't die.

A big fish: [In Old French]: "Baleine" [i.e., "whale"], or (something) similar to it. ${ }^{32}$

And Jonah was (in the belly of the fish): And Jonah survived ${ }^{33}$ in the belly of the fish, in that he didn't die.

Three days and three nights: On account of the day on which he was thrown into the sea and the day on which the fish vomited him up he knew that he was there three days and three nights. And when he was in the belly of the fish for a long time, and didn't die and was not changed,

31 Eliezer considers this an instance of rabbinic logic, qal va-homer, lit. "light and heavy," which term corresponds to Greek and Latin logic as an inference a minore ad maius, "from minor to major." However, Eliezer seems to actually argue here in the opposite direction, a maiore ad minus, i.e., "from major to minor." In either case, Eliezer is making an argument afortiori, "which applies to a situation in which if one thing is true then it can be inferred that a second thing is even more certainly true"; see http:// legal-dictionary.thefreedictionary.com/A+fortiori+argument.

32 בליינא, baleine. Eliezer's rendering of the Bible's "big fish" as "whale" seems to be unique in medieval Jewish exegesis. Matthew 12:40 had already understood the creature to be a whale, or some other great sea creature (in the Vulgate: sicut enim fuit Ionas in ventre ceti tribus diebus et tribus noctibus...; contrast Jerome's translation of Jonah 2:1 as piscem grandem). Old French "baleine" is sufficiently close to Latin to at least raise the possibility of Eliezer's exposure to Christian exegesis. Compare, e.g., Haimo of Auxerre's commentary on the verse: "Rather than great fish, the Lord said 'whale' in the Gospel, briefly interpreting the thing itself"; Everhart, Haimo (1993), 17.

33 Eliezer glosses the Hebrew ויהי, va-yehi, which typically begins a narrative sequence ("and it came to pass"), but here doesn't, with the word ויתקיים, va-yitkayem, "and he existed/survived." 
then he knew that the Lord didn't want to kill him, ${ }^{34}$ but rather to show him His strength and power, and to subdue his heart, that he should go on his mission; then Jonah prayed, and gave thanks, and praised.

2:2: There are Scriptural prayers which are petitionary, and there are those of praise and thanksgiving. In the latter category is Hannah's prayer ( 1 Samuel 2:1-10), which is entirely praise and thanksgiving; so is this one (i.e., Jonah's). ${ }^{35}$

2:3: I called: i.e., Yesterday, and the day before, when I was swallowed.

(I called) when there was distress to me: Out of my distress. ${ }^{36}$

And he answered me: (Indicating to me) that I was yet alive.

From the belly of She'ol: From the swallowing-up of She'ol. ${ }^{37}$

2:5: And as for me, I said - when I was swallowed ${ }^{38}-[$ I have been driven away from your sight]. But this is not so! Yet ${ }^{39}$ will I continue to gaze upon your holy temple, since I am still alive, for behold -

${ }^{34}$ Eliezer paraphrases Judges 13:23.

35 On the tripartite division of Jewish liturgy into categories of praise, petition, and thanks, for which Eliezer here claims biblical precedent, see Ismar Elbogen, Jewish Liturgy: A Comprehensive History (Raymond P. Scheindlin, trans.; Philadelphia: The Jewish Publication Society, 1993), 25, etc. That Eliezer associates two biblical prayers that don't quite fit the narrative context in which they are found is itself insightful.

36 Eliezer considers the Hebrew phrase מצרה לי, me-tzarah li, to be ambiguous; he clarifies by explaining it as a possessive.

${ }^{37}$ Eliezer thus changes the startling biblical figure of the noun "belly" into what we must assume he considered to be a less striking gerund.

38 Once again, Eliezer composes his commentary by interspersing his interpretation directly into the Biblical discourse. This is as good an example as any that indicates the lack of an absolute character to the incipit; it is not at all the case that Eliezer's commentary is composed on the basis of "text and then commentary," but rather, particularly when he senses the text to be especially laconic, he essentially expands the Biblical text under consideration.

${ }^{39}$ Eliezer has replaced the somewhat ambiguous Hebrew word אך, akh, ("but") with the contextually clearer עוד,'od ("yet"). 
2:6: The waters have gathered around me, even unto the soul: i.e., unto death!

Weeds twined — are attached — to my head, all around.

2:7: To the extremities of - the end of the roots of the mountains did I descend, and the mountains were bent over me, and I thought that the earth had closed its gates upon me forever, that I would never again come on dry land.

My life arose from the Pit: That I hadn't died, and that I am still alive.

2:8: The LORD did I remember: by saying the loving-kindnesses of the Lord, indeed they have not ended; indeed his tender mercies have not ceased (Lamentations 3:22), ${ }^{40}$ and I gave over my heart to praying to You.

2:9: They keep empty vanities: Other men await empty vanities ${ }^{41}$ to aid them, and to them do they offer thanks when You save them; the lovingkindness with which you have rewarded them do they abandon, and they do not recall you.

2:10: (And I) - whereas I, ${ }^{42}$ - with voice of thanksgiving, sacrifice to You.

That which I have vowed - in my distress - I will pay; salvation is the LORD's: and to you (is due) praise and psalmody.

${ }^{40}$ Eliezer cites Lamentations 3:22 in order to explain the type of admission by which Jonah "remembered the LORD."

41 This is likely a reference to "false gods." For a possibly later medieval use of the biblical term the meaning of which Eliezer would have nonetheless likely been aware, see Jeffrey Hoffman, "The Image of the Other in Jewish Interpretations of Alenu," Studies in Christian-Jewish Relations 10:1 (2015): 1-41 (14-18).

42 Once again Eliezer seamlessly inserts his commentary into the text of Scripture. Here, he changes the Hebrew's prefixed-(letter) conjunctive vav ("and") into "whereas" or "but," thus drawing out the contrast between speaker's reaffirmed belief and others who do not truly acknowledge their redeeming God. 


\section{Chapter Three}

\section{3:2: That which I speak to you: There. ${ }^{43}$}

3:3: (A great city) to God: And $\mathrm{He}$ is compassionate concerning it (and so will not) destroy it.

3:6: And the pronouncement reached the King of Nineveh: From those who had been within the distance (covered by Jonah) during the first day; for Jonah had not walked throughout the entire city, but one day's worth (of walking). ${ }^{44}$

3:7: And he proclaimed - (to) the people - by order of the King: by the counsel of the King and his decree.

Let them not pasture and let them not drink water: This is (Scripture's own) clarification of (the King's decree, earlier in this same verse): let them not taste anything. ${ }^{45}$

3:8, 9: Let them be covered (with sackcloth)... let them return (each man from his evil way)... who know, maybe (God) will relent...: All this (the King) caused to be cried out and decreed (i.e., in 3:7). ${ }^{46}$

43 With this briefest of comments, Eliezer indicates to the reader the force of the verb "speak" (actually the participle דובר, dover); although God is speaking here and now, Jonah should only utter the prophetic call ("forty days more, and Nineveh will be overthrown") there and then-i.e., only when Jonah will arrive in the city.

44 Thus Eliezer understands the phrase "a three day distance" in 3:2 to mean "it takes three days to walk across it." Contrast David Marcus, "Nineveh's 'Three Days' Walk (Jonah 3:3): Another Interpretation," in On the Way to Nineveh: Studies in Honor of George M. Landis (S. L. Cook and S. C. Winter, eds.; American School of Oriental Research, 1999), 42-53; Marcus demonstrates that the phrase actually means "it takes three days to reach it" (i.e., from where Jonah was when he received the prophetic call). For a survey of interpretations, see Sasson (1990), 230-31; Simon (1999), 28.

45 That Scripture typically resolves its own gaps is an observation made often by Eliezer's predecessor, R. Yosef Kara, a younger contemporary of Rashi. In particular, this is seen in Kara's comment on 1 Samuel 1:17: "Know well, that when Scripture was written, it was written completely, with every explanation and need taken care of, so that future generations would not stumble in it, and in its place, it lacks nothing."

${ }^{46}$ Eliezer's commentary on chapter three is thus quite brief. This is no doubt due in part to its being, in a sense, a recapitulation of chapter 1 . 


\section{Chapter Four}

4:1: And he was troubled: (This was so) because Jonah had not known about their repentance, for he had gone out of the city, as it is said below (in $4: 5) \cdot{ }^{47}$

4:2: And he prayed to the LORD: The prayer was take, I beg you, my soul $(4: 3) .48$

When I was yet in my own land: At rest, without being broken of body and limb.

Therefore did I flee beforehand towards Tarshish: To escape from You, that you should send another. ${ }^{49}$

For I know that You are (a compassionate and gracious God, slow to anger, abounding in kindness, renouncing punishment) and so would not destroy such a great city. It would then result that I would have exerted myself, broken my body and suffered so on the way, (losing) my strength for nothing. For Jonah thought that God had renounced the punishment without their having repented. ${ }^{50}$

4:3: And now, LORD, take, I beg you, my soul from me, for my death is better than my life: For I still have to exert myself and break my body to return home. And so in the same way did Elijah speak, as a result of the exertion of the road and being broken of body. ${ }^{51}$

47 Thus, in one stroke, Eliezer removes from Jonah the calumny of being an uncaring, vengeful prophet; had he but known that the Ninevites' repentance was genuine, he would not have minded that the city had been spared. In other words, not only had the Ninevites fasted and worn sackcloth, but, as is reported in 3:10, they had "returned from their evil way," and thus merited God's mercy. For a discussion of Eliezer's understanding Jonah 4:5 in a pluperfect sense, see Harris (2007), 90-91.

${ }^{48}$ Here, Eliezer understands prayer as only the petition of 4:3; the earlier portion of Jonah's discourse is "only" prophetic dialogue with God, and is not included in the terminology of "prayer." Contrast note 35 , above.

${ }^{49}$ See Eliezer's comment on 1:3.

${ }^{50}$ Eliezer here clarifies and expands his interpretation given on 4:1.

51 See 1 Kings 19:4: “[Elijah] went into the wilderness a day's journey, and he came and sat under a broom brush, and he prayed for his life, that he might die. He said, 'Enough! Now, LORD, take my life, for no better am I than my fathers!'” On the 
4:4: Have you done well (to be so grieved?): ${ }^{52}$ And is it a good thing that you have been so troubled about this? For even without repentance, I have compassion on the work of my hands. And it was according to (Jonah's) word and his manner that (God) responded to him, for even if it had been as (Jonah) thought (i.e., that God had forgiven the Ninevites without their having repented), (Jonah) shouldn't have been angry about it. ${ }^{53}$

4:5: (Jonah) had already ${ }^{54}$ gone out from the city, immediately after ${ }^{55}$ he had uttered his prophetic cry, one day's journey, for he feared to dwell in the city.

He dwelled east of the city: All of the forty days.

(Until he would see) what would happen to the city: i.e., at the end of the forty days. And now, at the end of the forty days, when he grieved over (God's) compassion for the (inhabitants), and that (God) didn't destroy them according to his ${ }^{56}$ word, then -

4:6: Then the LORD God provided a qiqayon ${ }^{57}$... To save him from his discomfort, for the sun was beating down on his head, through the booth. $^{58}$

connection between the figures of Jonah and Elijah, see Simon (1999), 38.

52 Here, my translation is in keeping with Eliezer's comment, which itself reflects the Hebrew ההיטב, ha-hetev. NJPS: "Are you that deeply grieved?"

53 While it cannot be said that Eliezer responds here to "anti-Jonah" diatribes in Christian anti-Jewish polemics, it is nonetheless true that he takes an even-handed approach to Jonah's character throughout the commentary, on occasion justifying Jonah's actions while at other times gently chiding the biblical figure.

${ }^{54}$ Eliezer interpolates the word "already" and changes the form of the Hebrew verb (see above on 4:1).

55 I have translated according to Poznanski's emendation, (1913), 159, n. 5. The MS has "before" (קודם, qodem) in the text here, which cannot be correct. Alternatively, one may read, with Cohen, Mikraot Gedolot Ha-keter (2012), 165, "Jonah had already gone out from the city, earlier, when he had uttered his prophetic cry."

56 This is a double entendre, referring to God's word, as well as to Jonah's own prophetic cry.

${ }^{57}$ For leaving the name of the plant untranslated, see Sasson (1990), 291-92. NJPS: "ricinus plant"; KJV, "gourd." See also Simon (1999), 42-43.

58 Thus Eliezer tries to reconcile the apparent contradiction between the shade 
4:8: A mild ${ }^{59}$ east wind: And not a fierce one. ${ }^{60}$ But there was not in (this wind) enough to ease the heat of the sun.

4:9: Have you done well to be so grieved ? $^{61}$ Is it a good thing that you are so troubled about the qiqayon? And (Jonah) replied, "Of course it is fitting that I should be so troubled about its loss, for it really served me well!" And on account of this, (God) responded to him about the matter of the city (as follows).

4:10: You cared (about the plant): In other words, the loss of the plant, which was not the work of your hands, made it hard for you. ${ }^{62}$

Which appeared overnight: ${ }^{63}$ (This expression) is like one year old (Exodus 12:5) (lit. "son of a year") or "one day old" (lit. "son of his day").

4:11: And should I not care about the work of my hand and the toil of my palms - not one or two (souls) but a great city?! Who do not know (to distinguish between right and left): i.e., between good and evil. And they do not sin out of spite or willfully; in any event, they only sin like babies and much cattle. And on their behalf, I would have pardoned the entire place, ${ }^{64}$ even if they hadn't repented, according to your (i.e., Jonah's) words. However, on account of (their) repentance, I had compassion on them. And here, (God) told him of their repentance.

provided by the sukkah, or booth, that Jonah built, and that of the plant furnished by God. See Sasson (1990), 289-90.

59 So according to Eliezer's commentary, which he derives from a unique reading of the Aramaic Targum שתיקתא, shetiqta. This word is taken by the other Jewish medieval commentators as meaning "fierce"; for example, Rashi explains, "Our Rabbis have taught: at the moment when (this kind of wind) blows, it silences all the other winds before it; it is very hot." NJPS, which notes "meaning of Hebrew uncertain," renders "a sultry east wind." Simon (1999), 43-44, offers a "quiet" east wind.

${ }^{60}$ Eliezer alludes to the wind mentioned in Exodus 14:21.

${ }^{61}$ See note on $4: 4$.

${ }^{62}$ Literally, "It was difficult in your eyes concerning the loss of the qiqayon."

${ }^{63}$ Literally, the phrase בן לילה, bin layla, translates as "son of the night." See Simon's discussion (1999), 45.

${ }^{64}$ See Genesis 18:26. 



\section{The Commentary of Rabbi Eliezer of Beaugency on Isaiah (Selections)}

\section{Eliezer's Introduction to His Commentary on Isaiah}

\section{The prophecy of Isaiah the son of Amoz who prophesied concerning Judah and Jerusalem during the days of Uzziah: From this extended lan-}

guage, it seems that it is the language of anprologus, i.e., "of (or concerning) the beginning." "And since he cited here these four kings, (it is because) he prophesied during their days. (This is) similar to the beginning of the prophecies of Hosea and Amos, and in the beginning of Jeremiah...And also from the language of hear, $O$ heavens, and give ear, $O$ earth (Isaiah 1:2), which is in the same vein as give ear, $O$ heavens, that I may speak (Deuteronomy 32:1), and so it is whenever there are two initial statements (in parallelism), that proves that this is the beginning of his prophecy. ${ }^{2}$

And also the order (of the oracles) will prove this. In the beginning (of the book it is written) in the days of Uzziah (Isaiah 1:1), whereas after-

1 The particular morpheme anprologus appears to be some sort of Old Frenchinflected Latin. Eric Lawee considers this to be "Hebraicized Latin," and he may well be correct; see again Lawee, "Introducing Scripture: The Accessus Ad Auctores in Hebrew Exegetical Literature From the Thirteenth Through the Fifteenth Centuries," (2003), 157-79 (159).

${ }^{2}$ Here, Eliezer argues against applying the ancient rabbinic exegetical principle, "There is no early nor late in Scripture," which enables interpreters to claim that a variety of factors may indicate that a given biblical text is out of chronological order. Whereas other exegetes (down to the present day) prefer to see Isaiah 6 as the prophet's "inaugural call," Eliezer states that Scripture itself indicates that the book's first five chapters reference earlier stages in the prophet's career. The fullest study of the rabbinic discussion of the chronological arrangement of Scripture (or its lack) is: Isaac Gottlieb, Order in the Bible: The Arrangement of the Torah in Rabbinic and Medieval Jewish Commentary [Hebrew] (Jerusalem, Ramat-Gan: Magnes Press; Bar Ilan University Press, 2009). English readers might read David A. Glatt, Chronological Displacement in Biblical and Related Literatures (Atlanta: Scholars Press, 1993). 
wards (it is written) in the year of the death of King Uzziah (Isaiah 6:1); still after that (it is written) and it happened in the days of Ahaz son of Jotham the son of Uzziah (Isaiah 7:1); after that (it is written) in the year of the death of King Ahaz (Isaiah 14:28); after that (it is written) it happened in the fourteenth year of King Hezekiah (Isaiah 36:1). According to a contextual interpretation, one should not say that In the year of the death [of King Uzziah] (Isaiah 6:1) should be understood according to the Targum: "in the year that he became a leper." 3 And from here until the year of the death of King Uzziah (Isaiah 6:1) he prophesied in the days of Uzziah, and in the days of Jotham after the death of his father; for these (kings) would not receive his rebuke, and he would rebuke them for those matters for which they were punished, and he would inform them what would befall them at their end.

(The opening words of the book,) The prophecy of Isaiah the son of Amoz who prophesied, refer to the entire book. For there are (prophecies that he prophesied) during the days of Jotham, and there are those (that he prophesied) during the days of Ahaz, and there are those (that he prophesied) during the days of Hezekiah, and each of these is made explicit in its place. And most of the prophecies from here until (the verse) and it happened in the fourteenth year of King Hezekiab (Isaiah 36:1) were spoken with regard to the king of Assyria, i.e., the matter closest to him. For it is with regard to them that Isaiah elaborates in many places, more than he does with regard to other future events. And from (the text beginning with the verse) And it happened in the fourteenth year of King Hezekiah... (Isaiah 36:1), when the events surrounding the king of Assyria took place, Scripture goes on to address the future consolations, ${ }^{4}$ which we will explain in the future, each one in its place, with the help of God who bestows understanding.

3 The midrashic interpretation that the Aramaic Targum expresses is itself rooted in the biblical narrative of 2 Chronicles 26:18-21.

${ }^{4}$ I.e., the prophecies in Deutero-Isaiah (Isaiah 40-66). While Eliezer did not go as far as Abraham Ibn Ezra in identifying those chapters as the work of a different prophet, he did recognize the prophecies beginning in Isaiah 40 as speaking to an exilic community. See his comment on Isaiah 40:1, which I reproduce below. See Uriel Simon, "Ibn Ezra Between Medievalism and Modernism: The Case of Isaiah XlLXVI," Vetus Testamentum Supplements 36 (1983), 257-71. 


\section{Isaiah 3:8}

And She (i.e., Jerusalem) shall stumble and fall, since their speech and their deeds are against the LORD, openly and brazenly, to rebel against his word, to vex him in the presence of His majesty, which dwells among them publicly. (The phrase beginning) For Jerusalem has stumbled harkens back to (the phrase beginning) for their speech; it (i.e., the first stich) is not the cause of what precedes it. Rather for their speech and their deeds [are against the LORD] is the primary cause (i.e., that Jerusalem has fallen). ${ }^{5}$ And this is the convention of Scripture in most places: when it wants to provide a reason for what it says, it repeats the words and (in so doing) gives their reason. ${ }^{6}$

\section{Isaiah 5:1}

Let me sing for my beloved (A song of my lover about his vineyard): It is the way of the prophets, ${ }^{7}$ when they want to cause their words to enter into the hearts of the people, that they draw their hearts to speak their words (according to) the way of poetry and figurative language. Certainly, the song $H^{\prime} a z i n u^{8}$ demonstrates this, for, although it is nothing other than reproofs and rebukes, it is nonetheless called $A$ Song (Deuteronomy 31:30). The reason for this is that since it is "the way of song," it shall be placed in their mouths ${ }^{9}$ and the words will come into their hearts.

${ }^{5}$ In other words, the fall is the consequence of the rebellion.

${ }^{6}$ I discussed this commentary in my book, Discerning Parallelism (see Harris, 2004, 76).

7 Eliezer uses the expression "the way of" to express ideas about poetics. In this he follows his teacher, Rashbam, who used such terms as "the way of Scripture" (with reference to the function of prolepsis in biblical narrative, at Genesis 1:1) as well as "the way of travelers" (with reference to hospitality, at Genesis 18:1) and the "way of the land" (with reference to how law functions in society, in his introduction to Exodus 21). See below on Isaiah 37:38.

${ }^{8}$ Eliezer refers to the speech of Moses in Deuteronomy 32, which he calls (according to Jewish liturgical convention) Haazinu, "Give ear (O heavens)," according to that poem's initial Hebrew word.

${ }^{9}$ See Deuteronomy 31:19. 


\section{Isaiah 5:7-9}

Injustice...outcry: (This is an example of ) a "tongue falling on a tongue." 10 It is similar to (the wordplay in) The houses of Achzib are a deceit (Micah $1: 14$ ) and the inhabitants of Zaanan came not forth (Micah $1: 11$ ). ${ }^{11} \mathrm{He}$ (the prophet) (goes on to) make explicit (what) the injustice and the outcry (are): Ah concerning those who add their house to the house of the poor his neighbor, by removing the boundary-marker, on a daily basis, until there is no room for the poor to dwell. And since the place has become so narrow for him, he goes away, on account of his oppression, and they (the wealthy) remain in the land by themselves...(then) to my ears - will come the cry (of the exploited).

\section{Isaiah 6:1}

In the year of the death of King Uzziah: This means (that the following events took place) after his death (in the same year); and this is what is referred to as in the days... of Jotham (Isaiah 1:1). ${ }^{12}$ Furthermore, if this had been said before his death, why then would Scripture have addressed us using the expression in the year of (his) death? Rather, of course it was after his death! And Scripture instructed us that when the Holy One, Blessed be God saw that Uzziah had died, and King Jotham (as well), and that that generation was not corrected (in its ways), then God appeared (again) to Isaiah. Moreover, it appears that since God appeared to him now by way of this strange vision, and said to him Whom shall I send, and who will go for us? (Isaiah 6:8), that already much time had passed in which God had not spoken with him and had not appeared to him. All of those prophecies preceding (this chapter) were said in the days of the earthquake that took place in the days of $\mathrm{Uzziah}^{13}$ — but then (God)

${ }^{10}$ Or: "language falling on language." In either case, this term, lashon nofel 'al lashon, occurs occasionally in ancient rabbinic midrash and, more frequently, among the northern French rabbinic exegetes, to express awareness of wordplay in biblical literature. See Harris (2009), 327 and n. 25, there.

11 Both of these phrases contain wordplay (mostly assonance).

${ }^{12}$ Eliezer understands the superscription to give a reliable indication of the book's order and structure. See above, in his commentary on Isaiah 1:1. It appears that he repeats some of his conclusions here since Isaiah 6 is frequently considered to be the inaugural call of the prophet - a view with which Eliezer does not concur.

13 See Amos 1:1. 
stopped (speaking with him). And now that Uzziah had died, God again began sending Isaiah to rebuke them.

\section{Isaiah 7:2}

(Now, when it was reported to the House of David that Aram had allied itself with Ephraim), their hearts and the hearts of their people trembled: For they had feared lest the time had arrived during which those prophecies were to be fulfilled. ${ }^{14}$ For these two kings had fought with them, each one on his own, with fierceness and a strong hand, and the House of David was not able to withstand them, how much the more so they would not be able to withstand them now that they were allied together. And the Omnipresent said to Isaiah: tell them that they need not worry from them, ${ }^{15}$ since the time had not yet come wherein those prophecies would be fulfilled. The king of Assyria would come upon the Land, and (only) then would they be fulfilled. This is the mode (of the passage). ${ }^{16}$ Aram had allied: "The kingdom of Aram has allied and joined with Ephraim, and they have made an alliance against you." ${ }^{17}$ Now they had not yet attacked him, but as for the redactor, ${ }^{18}$ his way is to relate at the

${ }^{14}$ Eliezer does not specify which prophecies. He may be referring specifically to Isaiah 5:26-29 or, more likely, to any and all of Isaiah's prophecies of doom in chapters $1-5$. In his comment on Isaiah 7:1, in any case, he also uses the term "those prophecies" to refer more generally to the first chapters of the book.

${ }^{15}$ I.e., tell the Judaeans that they need not fear the attack of the Aramaeans and the Israelites.

16 When Eliezer uses the term for "mode," it is not always clear whether he indicates the previous gloss, or an upcoming one. In the present case, it is possible to read it as either. Like many of his fellow northern French rabbinic exegetes, Eliezer distinguishes between the sense of a passage and the mode through which that sense is achieved. Whereas those exegetes, since the time of Rashi in the late eleventh century, regularly used such terms as peshuto (or, later, peshat), mashma or 'inyan to denote the sense of a biblical text, the only term they employed for the mode was an old rabbinic Hebrew word, shittah. The analogies among Christian exegetes were sensus litteralis for English "sense" and modus for "mode." Further exploration of this distinction are featured in my forthcoming book, "I Have Only Come to Explain the Context of Scripture": The Reinvention of Reading During the Twelfth Century Renaissance."

17 As he does frequently in his Isaiah commentary, Eliezer supplements his understanding of Isaiah by relying on parallel or corresponding passages in the Book of Kings; here, he draws on the narrative of 2 Kings 16.

${ }^{18}$ In a number of circumstances, Eliezer explicitly references "the redactor"; the 
beginning of his words the essential aspect of the matter briefly; this pattern is also found in Jacob left Beer-sheba, and he went to Haran ${ }^{19}$ (Genesis 28:10) and afterwards the text states He came upon a certain place (Genesis 28:11) and then later (does the narrator) make the matter beautifully explicit. ${ }^{20}$ First he said that Rezin and Pekah had attacked, and only later does he elaborate the matter: for when they joined forces to attack the House of David in war, it was told to (the House of) David, causing his (Ahaz's) heart to tremble; then he (Isaiah) told him not to fear. ${ }^{21}$

Hebrew term he employs is הסופר, ha-sofer. While it is true that the word can also mean simply "the scribe" (i.e. the copyist of a previously-written document), Eliezer repeatedly employs the term with respect to the creative arrangement of prophetically-disclosed materials (including the Divine word). Eliezer clearly learned this approach at the feet of his master, Rashbam; see the latter's commentary on Genesis 1:1, an English translation of which may be found in Martin I. Lockshin, Rabbi Samuel Ben Meir's Commentary on Genesis: An Annotated Translation (Lewiston, Lamperer, Queenston: The Edwin Mellen Press, 1989), 28-33.

${ }^{19}$ As will be made clear, Eliezer does not understand this phrase to mean "towards Haran," but that the verse states that Jacob reached Haran, and then the subsequent narrative goes on to describe an event that involved Jacob before he arrived at Haran (Genesis 28:11-22). Of course, the biblical narrator describes the events that took place in Haran only in Genesis $29 \mathrm{ff}$.

20 The narrative pattern that Eliezer observes has only imperfectly and infrequently been recognized, even among modern biblical expositors. In Harris (1997), 157-64, I termed this the "Summary and Elaboration" pattern. Eliezer was likely influenced by the ancient rabbinic legal hermeneutic principle, כלל ופרט, kelal u-ferat, "a general statement and a specific statement"; whereas the rabbis had considered this a restrictive principle, Eliezer applies the rule more broadly to narrative contexts. See Harris (2006), 182-83; and Harris (2009), 318-20.

21 Thus Eliezer states that Isaiah 7:1 relates in miniature the entire narrative concerning the invasion of Aram and Israel against Judah, concluding "but they were not able to attack it," thus, the invasion did not succeed. Isaiah 7:2ff relates the specific events on which the prophetic narrative centers. 


\section{Discursive Analysis}

Isaiah 7:13-16 22

Is it not enough for you to treat men as helpless: (The word men refers to) the prophets of the Lord, whose words you did not believe, that you also treat my God as helpless, to glower at him, in not asking of him a sign, as if you do not want that it should inform you that it is from God that your help comes, and through God you will be saved, and that you should acknowledge that he is your God, your Deliverer! Now (the prophet) who now says my God, had above said: your God (Isaiah 7:11); (the earlier usage was) to make God more beloved in the king's eyes, so that the king would request a sign from God. But when Isaiah saw that (the king) disparaged God's signs, he said my God, and not your God. Therefore shall He (my Lord) give you of his own accord a sign, for the honor of His own name, and against your will shall you acknowledge and recognize that he is a God who saves and aids in (times of) trouble, and your salvation (shall come about) through none but Him. Behold the young woman: From this language shall you (the reader) understand she was known and identifiable to them. ${ }^{23}$ Moreover, I say that according to

22 Christian exegesis of Isaiah 7:14 is, of course, well-known. From the longer pericope of Isaiah 7:10-25, I have excerpted Eliezer's commentary, as indicated, to demonstrate to the reader the degree to which Eliezer interprets strictly according to literaryhistorical considerations.

23 Thus in a stroke Eliezer disclaims any long-term prophecy from being associated with this verse. While it ought not be claimed that Eliezer engages here in overt antiChristian polemics, it is nonetheless clear that Eliezer firmly roots his interpretation in the context of eighth century, B.C.E. Israel - and thus effectively disallows Christian theological interpretations that use this passage to point forward to the birth of Jesus. On the effort among Jewish exegetes to discredit messianic interpretation, certainly for polemical purposes but also at the expense of potential Jewish messianic hopes, see Robert A. Harris, "Rashi and the 'Messianic' Psalms," in Birkat Shalom: Studies in the Bible, Ancient Near Eastern Literature, and Postbiblical Judaism Presented to Shalom M. Paul on the Occasion of His Seventieth Birthday (C. Cohen, V. Hurowitz, A. Hurvitz, Y. Muffs, B. Schwartz, and J. Tigay, eds., Winona Lake, Indiana: Eisenbrauns, 2008), $845-62$. 
the (will of) the Omnipresent did he marry her, ${ }^{24}$ as a sign and a portent, ${ }^{25}$ as Hosea the son of Be'eri had done, who was of (Isaiah's) generation, ${ }^{26}$ only this one was not a wife of whoredom (Hosea 1:2). Shall conceive: She shall conceive now, that which is not usual with a young woman, for the way of a man with a young woman (Proverbs 30:19) is wondrous, and it was not known that she had engaged in intercourse, for she had not yet conceived, so did Solomon testify. ${ }^{27}$ And shall conceive means subsequently, as in the case of Manoah's wife. ${ }^{28}$ Moreover, the conception of a young woman, whose way is not to become pregnant, is usually quite difficult; and even if she becomes pregnant, the birth of a first-born is quite difficult. And when this one would suffer terrible travails during her pregnancy, and yet give birth and be relieved, so too shall you (Judaeans) be relieved in spite of the terrible travails (that you endure), like her. And it is the way of Scripture ${ }^{29}$ to compare trouble with pregnancy, and relief as birth, as in the context of: (Thus said Hezekiah: This day is a day of distress, of chastisement, and of disgrace.) The babes have reached the birthstool, but the strength to give birth is lacking (Isaiah 37:3). Thus, this (announcement of conception) was the sign given with respect to the relief (that would follow the invasion) of Rezin and Pekah. And how would it be known that this would be (the sign)? For she would herself call his name Immanuel, by agency of the Holy Spirit, as though to say "The Lord is with us" (and as was narrated with respect to): There are more on our side than on theirs ( 2 Kings 6:16), ${ }^{30}$ i.e., they shall not prevail against us. And this is what Scripture states further on: Hatch a plot - it shall be foiled; Agree on action - it shall not succeed. For with us is God! (Isaiah 8:10). Thus this is one sign that they (the Judaeans) shall be saved from these two kings. And one additional sign shall be the child, for even as his land shall be destroyed eventually by Sennacherib...Now, in the days of Ahaz,

${ }^{24}$ As his predecessors, Rashi and R. Yosef Kara, had interpreted, so does Eliezer understand the woman involved to be Isaiah's own wife; see Isaiah 8:3-4.

${ }^{25}$ Used in conjunction with prophetic acts and messages, see Deuteronomy 13:2.

26 See Hosea 1:1.

27 See Proverbs 30:18-19.

${ }^{28}$ See Judges 13:5. In other words, God's angel announced she would get pregnant, and then she did so, in the very near future.

${ }^{29}$ On Eliezer's use of "the way of" to indicate general rules of poetics, see above at Isaiah 5:1 and below in his introduction to Ezekiel.

${ }^{30}$ See the narrative in 2 Kings 6:8-18. 
after the birth of Immanuel, forthwith, when the kings retreated from him (Ahaz), Tiglath-Pileser, King of Assyria, attacked Aram and exiled it to Kir, and thus they returned to their homeland, ${ }^{31}$ to the place from which they had originally come, as it is written: (True, I brought Israel up From the land of Egypt), But also the Philistines from Caphtor And the Arameans from Kir (Amos 9:7). And he (Tiglath-Pileser) conquered Damascus and killed Rezin. ${ }^{32}$ Also the Galilee and the Gilead, all of the land of Sihon and $\mathrm{Og},{ }^{33}$ and Zebulon and Naphtali did he (Tiglath-Pileser) exile from their lands. ${ }^{34}$ Thus this was the sign with regards to the destruction of the kings (who attacked Judah), that they would be destroyed and do evilly to them.

\section{Isaiah 9:5(6) ${ }^{35}$}

A child has been born: A son in the House of David (has been born) to the king, (this son is) Hezekiah. ${ }^{36}$ Authority shall be on his shoulder, and not like his father, for the rod of Assyria was on his shoulder and was his burden, ${ }^{37}$ as it was written: in that day his burden shall turn aside from your shoulder (Isaiah 10:27); For the yoke of his burden, and the staff for his shoulder (Isaiah 9:3). And by means of the authority that the Omnipresent shall place on his shoulder, he shall call ${ }^{38}$ his name, shall the Holy One,

${ }^{31}$ Literally, "the place of their implantation," which Eliezer himself goes on to explain.

32 See 2 Kings 16:9.

33 See Numbers 21:21-35.

${ }^{34}$ See 2 Kings 15:29.

${ }^{35}$ MT 9:5; translations following the tradition of LXX and Vulgate list this verse as 9:6. As elsewhere, my translation of the verse follows Eliezer's commentary, not the standard translations.

${ }^{36}$ In most of the particulars that follow, both in understanding of contents and syntax, Eliezer hews closely to the exegesis of Rashi.

${ }^{37}$ Literally, "on his shoulder and his burden."

38 Eliezer (and Rashi) interpret the MT, which vocalizes the Hebrew as a transitive verb, "He shall call," and not "shall be called," as the LXX and Vulgate (and other ancient translations) present it. This, of course, becomes a crucial point in the ongoing Jewish-Christian polemics surrounding the interpretation of the verse. Eliezer (and Rashi) understand the subject of this transitive verb to be God, and thus they understand the verse as describing a moment when God gives the Davidic heir apparent a new throne name. As Eliezer goes on to explain, this custom was quite prevalent in ancient Israel. 
Blessed be He (call), He who is a Wonderful Counselor, wondrous of counsel, and expansive in wisdom, saving and aiding even if only a little; ${ }^{39}$ a Mighty God to help and save; he is an Eternal Father, in that He exists forever - He shall call (the child's) name, Prince of Peace, for the purpose of renewing his name when he ascends to the throne, like Jedidiah (2 Samuel 12:25); ${ }^{40}$ Zaphenath-paneah (Genesis 41:45); ${ }^{41}$ Belteshazzar (Daniel 1:7); ${ }^{42}$ Tirshatha (Nehemiah 8:9); ${ }^{43}$ Joshua (Numbers 13:16). ${ }^{44}$ All of these refer to the innovation and addition of a name on account of some matter; and here, concerning what matter did (God) innovate and add to Hezekiah this name, Prince of Peace? (God called him) Prince, on account of increase in authority (Isaiah 9:6), since (Hezekiah) will prevail and will become much greater than his ancestors before him, and Peace, peace without limit (Isaiah 9:6), that there should be in his day Upon David's throne and kingdom (Isaiah 9:6), that no man should arise upon the House of David to depose his kingship and his throne, as Pekah and Rezin did when they attacked Ahaz his father, to enthrone a different king in Judah, and as the kings of Assyria sought to do. ${ }^{45}$ And from here one can respond

39 The last two words of Eliezer's comment are a puzzling locution. He appears to be saying that the name means God "does wondrously and increases understanding in order to save and help, even if it helps only a bit." However, it is curious that a rabbinic commentator would state that about God's salvific powers, even if he thought that were to be the true meaning. A conjectural emendation yields, "to the smallest degree," i.e., that God's power to save extends not only on an international scale but even to the smallest detail of one person's life.

${ }^{40}$ According to the preferred reading of the MT, Bathsheba had named her child "Solomon" (2 Samuel 12:24) but God, via the prophet Nathan, renamed him "Jedidiah," a name meaning that he was "beloved of the Lord."

${ }^{41}$ Pharaoh gave Joseph a new name when the latter became his ruling Viceroy.

42 Nebuchadnezzar's chief officer gave this name to Daniel when he entered the King's service.

${ }^{43}$ Eliezer understands this royal title as a new name.

${ }^{44}$ Eliezer follows his teacher, Rashbam, who in his commentary on Numbers 13:16 (when Moses changes Hosea son of Nun's name to Joshua) offers precisely the interpretation that Eliezer gives here. See Martin I. Lockshin, Rashbam's Commentary on Leviticus and Numbers: An Annotated Translation (Providence: Brown Judaic Studies, 2001), 207 (and n. 15, there).

45 Thus Eliezer reads Isaiah 9:6 as containing the key to understanding 9:5: since verse 6 offers an interpretation only of the (new) name "Prince of Peace," and not the other titles contained in 9:5, it is clear that God bestowed only the title "Prince of Peace" upon the young heir apparent, the other names belonging to God, alone. 
to the heretics: ${ }^{46}$ for it is impossible to dispute that out of all those names Scripture only gives an accounting of Prince of Peace, and if all of those names were for the child, (the following verse) would have had to give an accounting of Wonderful Counselor, Mighty God, Eternal Father, since (the child) was born of a woman, why would (God) call him by Divine names? (This would be true) only if he were (actually) a son of God! But certainly, the heretics lie, ${ }^{47}$ and they have counterfeited their books to read (as though the biblical verb was) "and his name shall be called," 48 so that all the names (in 9:5) would refer to the child, but they ${ }^{49}$ have accomplished nothing!

\section{Isaiah 20:2}

(At that time the LORD had spoken by Isaiah son of Amoz, saying, "Go), untie the girding of the belt of sackcloth from your loins: with which you girded yourself for Israel when they were exiled from their land, like the context further on: My Lord GOD of Hosts summoned on that day To weeping and lamenting, To tonsuring and girding with sackcloth (Isaiah 22:12); and like the context of: For this, put on sackcloth, Mourn and wail (Jeremiah 4:8); But I, upon their sickness, my clothing was sackcloth (Psalm $35: 13$ ). And like these there are many instances that teach you: the prophets and holy men wore sackcloth when distress (came upon) their people. Concerning this the prophet said, Yet it was our sickness that he was bearing (Isaiah 53:4). Also concerning Jehoram the son of Ahab you see that he wore sackcloth on his flesh, outside, concerning the distress of his people. ${ }^{50}$ And if you should say: where did the text relate to us that he had put on sackcloth? There are many statements in Scripture that the text doesn't relate at first, and only informs you about them in its own way. And the

\footnotetext{
46 On the significance of this phrase in Jewish-Christian polemic, see the introduction.

${ }^{47}$ Literally, "there is deceit in their right hands," a biblical idiom (see Isaiah 44:20; Psalms 144:8, 11).

${ }^{48}$ Again, Eliezer is not aware of the presumably different Hebrew model underlying the ancient Greek and Latin versions, and assumes that the Christians have deliberately falsified their Bibles so as to enable the Christological interpretation.

${ }^{49}$ I.e., the Christian interpreters, a reference to Jerome's Vulgate.

50 See 2 Kings 6:30.
} 
reason for this is that it did not want to interrupt its narrative sequence ${ }^{51}$ on this account, and no other place for it presented itself. And the sackcloth of Jehoram will prove (the point): Where did the text inform you that he was wearing sackcloth? When it said: as he walked on the wall), the people could see that he was wearing sackcloth underneath (2 Kings 6:30). ${ }^{52}$

\section{Isaiah 30:15-16}

And God's judgment is correct $!^{53}$ For thus had said my Lord God, the Holy One of Israel, whom you had spurned to become sanctified in his paths, when he warned you not to go to Egypt: why go to Egypt, to exert yourself and to enter into the dangers of the desert road, and to waste your money! Be still each man ${ }^{54}$ (Exodus 16:29), sit and rest from this road, and be saved. In calm and confidence shall come your victory against the king of Assyria, against whom you shouldn't fight, and whose name you needn't fear. (This is) like what (Isaiah) said to Ahaz: Be firm and be calm; don't be afraid, etc. (Isaiah 7:4). And this passage is in the mode of: Have no fear; stand up, and see the deliverance of the Lord! (Exodus 14:13). ${ }^{55}$ But you refused: if God had said to you, "Carry large stones, and they will be (an agency) through which to be saved," you would have listened to him. How much the more so (should you listen to him), since he told you to be calm and relaxed and to have confidence, that you should have listened to him! But you said: no, rather on a horse shall we be saved by fleeing on it, if the hand of the king of Assyria shall prevail against us, for that purpose we need to go to Egypt. On a swift (horse) shall we mount: to escape on it. And therefore: since you have said, Your pursuers shall be swift, thus everything will be for you the opposite (of what you planned). ${ }^{56}$

${ }^{51}$ Literally, "its mode"; see above on Isaiah 7:2.

52 The literary principle that Eliezer identifies here is analepsis, or "flashback technique." It is the functional opposite of prolepsis, or "foreshadowing," for which we shall provide an example, below. For a discussion of this comment, see Harris (2009), 321-22.

53 Literally, “and the judgment is with him.” Thus, Eliezer justifies God's proclamation of doom against the people in verses 12-14.

${ }^{54}$ Or: "Let everyone remain where he is" (NJPS).

55 That is, the two verses share the same rhetorical sense.

${ }^{56}$ Eliezer's comment on Isaiah 30:15-16 is a parade example of his tendency to meld his own observations into the Scriptural verses upon which he is commenting. 


\section{Compositional Technique}

\section{Isaiah 36:1}

See, these are the prophecies that I prophesied over Assyria, in the days of Ahaz and in the year of his death, (and) after his death during the reign of Hezekiah, that it (Assyria) would be consumed by fire. ${ }^{57}$ And when (Assyria) came in the fourteenth year of King Hezekiah, Sennacherib, King of Assyria went up against all the fortified cities of Judah. And then came his downfall, and all of these prophecies were fulfilled. And also the redactor has determined ${ }^{58}$ his own order: after the year of the death of King Ahaz (Isaiah 14:28), (then) the fourteenth year of Hezekiah. And he captured them: ${ }^{59}$ this was another event, when Hezekiah sent silver to him, which is described in (the Book of) Kings, ${ }^{60}$ but the redactor anticipated to tell you there ${ }^{61}$ and he captured them, which is the end of the episode. And since (Sennacherib) had already gone on to capture them, having already captured most of them, he sent him (i.e., Hezekiah) his emissaries. ${ }^{62}$

57 Thus, Eliezer views the narratives in Isaiah 36-39 as though composed by the author Isaiah himself.

${ }^{58}$ Literally, "seized," a typical word Eliezer employs when articulating the role of the redactor. There is no contradiction between Eliezer's view of the complementary roles of prophet and redactor in biblical composition. Inheriting the perspective from his teacher, Rashbam, Eliezer views the composition of Scripture as one developed in three stages: first, the God "speaks" to the prophet (that is, "places the Divine word within him"); the prophet then speaks the word in his (or her) own voice and style; finally, a redactor composes the book as we now have it, choosing his own order and structure through which to present the material. See Eliezer's introduction to Ezekiel (below), and Harris (2009), 315-16; a fuller discussion of medieval Jewish attitudes towards biblical redaction may be found in Robert A. Harris, "Awareness of Biblical Redaction Among Rabbinic Exegetes of Northern France," Shnaton: An Annual for Biblical and Ancient Near Eastern Studies Volume XIII (2000): 289-310 (Hebrew, with English summary).

59 Isaiah 36:1 repeats 2 Kings 18:13.

${ }^{60}$ See 2 Kings 18:14-16.

${ }^{61}$ I.e., at 2 Kings 18:13, end.

${ }^{62}$ I.e., the narrative contained in 2 Kings 18:17ff//Isaiah 36:2ff. Note that in trying to reconcile the various particulars between the parallel accounts in Isaiah and 2 Kings, Eliezer refers to the literary principle of "prolepsis," or "literary anticipation/ foreshadowing." See below on Isaiah 37:38. 


\section{Isaiah 37:38}

His son Esarhaddon succeeded him as king: Nevertheless, powerful Assyrians ceased coming into the Land, because the fear of the God of Israel had fallen upon them. And that is what it says below: and from the hand of the King of Assyria I will save you (Isaiah 38:6). And if (the redactor) had not anticipated ${ }^{63}$ to say and his son Esarhaddon reigned after him, you would have wondered from whom Hezekiah was in fear, that God would need to strengthen his heart. ${ }^{64}$

\section{Isaiah 40:1}

Since he stated two prophecies earlier: from Assyria, and from all of the rest of the nations that did evilly to Israel, such as Approach, $O$ nations, and listen (Isaiah 34:1), (and one spoken) about Assyria, in the fourteenth year... (Isaiah 36:1), and he related to you that which happened in the end to Assyria after he had related what had happened to the rest of the nations, therefore he then went on to relate to you the consolation of Israel with regard to all of these, from all of the exiles: Comfort, oh

${ }^{63}$ Hebrew, הקדים, hiqdim; this is the typical term that the northern French exegetes employ to express awareness of literary anticipation in biblical narrative. Thus, Eliezer, following in the footsteps of his teacher, Rashbam, identifies prolepsis as a prominent characteristic of biblical composition. Note that the reason Eliezer gives for the principle is that so readers "should not wonder" at the inclusion of a specific narrative description earlier on; this consideration provides a fascinating window into the attitudes of medieval exegetes for the Bible's readers, and their presumption that this consideration had been in place since the biblical text was first composed. For a brief discussion on medieval exegetical consideration of the role of the reader, see Robert A. Harris, "The Reception of Ezekiel Among Twelfth-Century Northern French Rabbinic Exegetes," in After Ezekiel: Essays on the Reception of a Difficult Prophet (Andrew Mein and Paul M. Joyce, ed., New York, London: T\&T Clark International, 2011), 71-88 (87-88).

${ }^{64}$ For a brief discussion of this particular passage, see Harris (2009), 316-18; for a fuller examination of the way in which Rashbam invoked his understanding of prolepsis as a principle in biblical composition, see Lockshin (1989), 400-21. Among modern scholars who discuss prolepsis in biblical composition, and who recognize Rashbam's precedence in identifying its fundamental features, see Nahum Sarna, "The Anticipatory Use of Information as a Literary Feature of the Genesis Narrative," in The Creation of Sacred Literature (R. E. Friedman, ed. Los Angeles: University of California Press, 1981), 76-82. 
comfort (My people), only comfort; ${ }^{65}$ this is the language of urgency and strengthening, as in on the road, on the road (Deuteronomy 2:27); round and round (Ecclesiastes 1:6), ${ }^{66}$ Says your God: you, My prophets. ${ }^{67}$

\section{Isaiah 58:3}

So do (the people) ask me: Why, when we fasted, did You not see? You shall respond to them, from me: you should not wonder about this! Because on your fast day you only sanctify a fast for your own purposes, to find business ${ }^{68}$ for yourselves and for that which you seek, (which is) for every man to lend to his fellow, (instead of) forgiving his debt. ${ }^{69}$ (In) all affairs with which you occupy your hearts, concerning your deeds during the fast and (when you are supposed to) afflict yourselves, ${ }^{70}$ (instead) you oppress each man his brother. For since you proclaim a fast through which you might be considered righteous and return to each person the money of his fellow, you find your debts and oppress especially those who have nothing, and subdue them. (In interpreting thus), it follows that

65 The northern French exegetes are aware that the two most prominent genres of prophetic rhetoric are "rebuke" and "consolation"; see, e.g., Yosef Kara on Isaiah 1:18: "Let it be known to you! This attribute is followed throughout Scripture: In every place that you find rebuke in Scripture, and at the conclusion of the rebuke there is an interruption..., and the context that follows it speaks of consolation, do not let your heart distract you and drive you far from the context that follows the interruption from the context of what had preceded it, (just) because you found an interruption there. For the context of what follows comes for no other reason than to bind up the wound of (the rebuke) that preceded it and to heal the bruise of the wound." See Harris (2006), 184 and n. 42, there. Thus, here Eliezer understands God's instructions to the prophets to "only" give consolation in the series of exilic prophecies that follow.

${ }^{66}$ I have rather literally translated the two biblical verses Eliezer cites; cf. the more idiomatic translation of NJPS: I will keep strictly to the highway (Deuteronomy 2:27) and Ever turning (blows the wind) (Ecclesiastes 1:6).

${ }^{67}$ Since the words Comfort, oh comfort (My people) and the pronoun your are in the plural form, Eliezer understands that God addresses here a group of prophets.

${ }^{68}$ As will be made clear from Eliezer's comment, by paying attention to the parallelistic structure of the (poetic) prophetic statement, he understands the verse to mean, "On the day of your fast, you see to your business; In all of your affairs, you oppress." Contrast modern translations.

${ }^{69}$ Literally, "returning his debt." Curiously, Eliezer uses the rare Hebrew word שי here; in the Bible, it appears only in 2 Kings 4:7.

70 See Leviticus 23:27; cf. NJPS, which renders "practice self-denial." 
and (in) all your affairs is parallel ${ }^{71}$ to on the day of your fast, and you oppress is parallel to you see to your business. The language of from doing business proves later on (i.e., in Isaiah $58: 13)^{72}$ that you see to your business (here, in Isaiah 58:3) refers to (the people) proclaiming a fast in order to do business.

${ }^{71}$ Following his teacher Rashbam and other medieval Jewish exegetes, Eliezer employs the Hebrew word כפל, kefel, "(it is) doubled" as a technical term to express his awareness of parallelism. The northern French expositors do not generally point to parallelism in terms of poetic theory but rather identify it as a structure through which they might better understand poetic prophetic rhetoric and the meaning of specific (and often difficult) words. For a full study of this usage in the Northern French School, see my monograph, Discerning Parallelism (Harris, 2004).

72 Thus, Eliezer claims that the end of the prophetic statement (Isaiah 58:13-14) clarifies how he understands the present verse: "If you refrain from trampling the sabbath, From pursuing your affairs on My holy day; If you call the sabbath 'delight,' The LORD's holy day 'honored'; And if you honor it and go not your ways nor look to your affairs, nor strike bargains - Then you can seek the favor of the LORD." 


\section{The Commentary of Rabbi Eliezer of Beaugency on Ezekiel (Selections)}

\section{Eliezer's Introduction to His Commentary on Ezekiel ${ }^{1}$}

Oh, mortal, with your eyes see and with your ears hear, and set your heart on (Ezekiel 40:4) the language of this prophet, for it is wondrous and most obscure, and brief. And even our Rabbis, peace be upon them, [thought] his words seemed to contradict the words of the Torah, ${ }^{2}$ on account of their obtuseness and brevity. Whereas I have informed you this day - yes, you (Proverbs 22:19) to enable you to recognize his modus and his discourse. And see, at the beginning of his words, he did not make explicit to what reckoning he counted (in the) thirtieth year (Ezekiel 1:1). And even though the words of the (Aramaic) Targum (lit., "the translator") are correct and wellfounded, (that the reference is) to the time when Hilkiah the Priest found the book of the Torah, ${ }^{3}$ in any event this is not the way of Scripture (in reckoning years). Yet "against our wills," (as it were), we have no way other than it, even though we do not know why he saw fit to count from there, in this context.

Nevertheless, according to what is apparent within the context of the entire book, we will endeavor to find meaning. Indeed, you do not find another prophet who rebukes his generation according to the Torah and the commandments other than he; moreover, his very discourse in most of his words is as the discourse of Torah. ${ }^{4}$ He virtually repeated for them all

${ }^{1}$ For a more extensive discussion of Eliezer's introduction to Ezekiel and his comment on the book's first verse, see Robert A. Harris, “The Reception of Ezekiel Among Twelfth-Century Northern French Rabbinic Exegetes” (2011), 71-88 (84-86).

${ }^{2}$ See, e.g., BT Shabbat 13 b.

3 See 2 Kgs 22:8.

${ }^{4}$ Possessed of a fine intuition, Eliezer senses that the language and style of Ezekiel closely resemble that of the Priestly Torah (in particular, Leviticus), much as modern scholarship might draw a connection between the language and style of Jeremiah and Deuteronomy. 
of the Torah — and you see will my words proved in many contexts - and since the Scroll of the Torah was revealed to them in his days, whereas he was in the Exile, where there were no priests nor prophets as there were in the Land [of Israel], he would rebuke them according to the (newly) found Scroll of the Torah, as one who renews for them the Torah, for it had been forgotten in the days of Menashe. And since on this Scroll of the Torah which had been found were his prophecies and his words (based), for that (reason) he counted from the time of its finding, for the principle of his book was founded on that.

\section{Ezekiel 1:15}

On the fourth [month] of the thirtieth year... ${ }^{6}$ the heavens opened: neither in a vision or in dreams, but rather as (in) Daniel. ${ }^{7}$ And I saw visions of God...I looked, and lo, a stormy wind... (Ezekiel 1:1,4): Ezekiel's words did not continue from the beginning, and even his name he did not make explicit, since the context of the book will make it clear below, as in and Ezekiel shall become a portent for you (Ezekiel 24:24). And, relying on this (later verse), he allowed himself to abbreviate (here, at the beginning of the book), as I have told you (above, in the introduction) with regard to [in the] thirtieth year, that (in that verse) the content of the book provides the proof for its (meaning, i.e., of the "thirtieth year"). But the redactor ${ }^{8}$ who assembled (lit. "wrote") all of his words together added

5 To be sure, the MS does not make the distinction I am making here between "introduction" and "commentary." See Harris (2011), 85, n. 37. On the distinction between medieval exegetes' introductions to biblical books and the commentaries, themselves, see Robert A. Harris, "Rashi's Introductions to His Biblical Commentaries," in Shai Le-Sara Japhet: Studies in the Bible, Its Exegesis and Its Language (Moshe Bar-Asher, Dalit Rom-Shiloni, Emanuel Tov, and Nili Wayzana, eds., Jerusalem: The Bialik Institute, 2007), 219-41 (English section).

${ }^{6}$ Eliezer deftly transposes the word order of the verse and slightly rewrites it, thus making clear to his readers that the biblical phrase, that might otherwise be interpreted as "thirty years," would of a certainty be understood as "in the thirtieth year."

7 See Daniel 10:4ff.

${ }^{8}$ Lit. "scribe," ha-sofer. However, what Eliezer has in mind is not merely the "copyist" of a prophetic text but, as the comment makes clear, specifically refers to a redactor, the individual - though not explicitly in communication with the Divine - responsible for the present composition of the Biblical text. Contrast Rashi, who attributes the disjunction between vv. 2-3 and vv. 1, 4 not to a human redactor, but to God: "The prophet made his words obscure. He did not make his name explicit, i.e., who he is; 
to what (Ezekiel) had left unclear and abbreviated, in these two verses (i.e., Ezekiel 1:2-3).

\section{Ezekiel 1:4}

A gleam as of hashmal: We are compelled (to interpret): to a thing which is visible to us does the prophet compare. ${ }^{9}$ This is similar to the following cases: (The wheels... gleamed) like beryl (Ezekiel 1:16); like the appearance of torches (v. 13); like a terrible frost (v. 22); like the appearance of lightning (v. 14); like burnished bronze (v. 7); like the appearance of the rainbow (v. 28): all of these are visible to the world. So, too: as of hashmal, this is a thing in the world, but we are not expert in the language of Scripture in so many areas, and we only have the context; but its context indicates that its meaning is very, very lucid and bright radiance, like the radiance of the sun's rays, when it appears to ebb and flow like waves of water, ${ }^{10}$ like a consuming flame out of the midst of the fire.

\section{Ezekiel 1:27}

And I saw by the frost ${ }^{11}$ [something] like hashmal: He returns to the beginning of the vision to complete it and to make explicit things that he heard from it. ${ }^{12}$ How did [something] like hashmal [function]? Like the

nor did he make explicit according to what reckoning he counted. Therefore, the Holy Spirit interrupted his words in the two verses juxtaposed to this (i.e., Ezekiel 1:2-3), to teach who is the prophet and to teach according to what number he counted... and these two verses interrupt his words as if someone else were speaking about him." See Harris (2011), 86, nn. 39-40. Certain Latin exegetes make similar distinctions between scriptor and auctor; see, e.g., the citation from Boneventure in J. A. Burrow, Medieval Writers and Their Work: Middle English Literature 1100-1500 (Oxford; New York: Oxford University Press, 2008), 30-32. See also Gary Day, Literary Criticism: A New History (Edinburgh: Edinburgh University Press, 2008), 88-89.

9 This explanation appears to be similar to that offered by the commentary on Ezekiel attributed to Yosef Kara (1:4): "a man doesn't teach his students (by comparing) to something that is hidden, but rather (does so to) something that is visible and recognizable."

${ }^{10}$ See Edward L. Greenstein, "Medieval Bible Commentaries," in Back to the Sources (Barry Holtz, ed., New York: Summit Books, 1984), 212-59 (248).

${ }^{11}$ See Ezekiel 1:22.

12 Eliezer points here to the literary device known as "resumptive repetition" (sometimes better known by the German term Wiederaufnahme), a literary device used 
appearance of fire I saw a house for it - upwards of the fire was hashmal, surrounding the fire, but below the loins was only fire, without hashmal. And all this [was] the Glory surrounding the Great King, but He Himself he [the prophet] did not see, only the semblance of a human form (v. 26), as though upon its arrival. And even the enwrapping of its light and the clothing of its splendor and majesty he did not see except by the frost ( $\mathrm{v}$. 22), for from downwards to upwards he saw everything, but the firmament separated between them. And all of the prophets who saw [God's] Glory - like Micaiah son of Imlah (see 1 Kings 22:19) and Isaiah and others like them - thus did they see Him, on a high and lofty throne (Isaiah 6:1), i.e., that the firmament of the throne separated [between the lower and upper "parts" of the Divine Presence]. Whereas Moses - the Glory would descend upon him and speak with him mouth to mouth (Numbers 12:8), and so, too, the Patriarchs.

\section{Ezekiel 10:4}

And when the presence of the Lord rose from the cherub to the platform of the Temple, the Temple was filled with the cloud and the court filled up with the radiant presence of the Lord:...It's impossible to say that at this point the presence of the Lord rose from off the cherub to the platform (of the Temple), since (Scripture) had already said: now the presence of the God of Israel had alighted from the cherub on which it had rested, to the platform of the Temple (Ezekiel 9:3). Moreover, we have not seen that (the presence) had returned to the cherub subsequently, that (Scripture) should now say and it rose... from off the cherub. Additionally: why should it (now) alight (on) to the platform of the Temple? It's getting ready to leave! The entire mode is confused with this (kind of reading). ${ }^{13}$ But this is the explanation: when (the presence of the Lord) rose (should be understood) as we have explained. And since (Scripture) has said that when (God's presence) was getting ready to leave, the courtyard filled up

to express synchroneity and simultaneity in biblical narrative. For a full discussion of this passage, see Harris (2009), 323-25. Thus, Eliezer states that Ezekiel 1:27 resumes that aspect of the vision that the prophet had last narrated in verse 4.

${ }^{13}$ Eliezer thus perceptively alerts his readers not to read this prophetic narrative as though it were in linear sequence. As we saw earlier with respect to his commentary on 1:27, Eliezer states here that Ezekiel 10:4 resumes that aspect of the prophetic vision that he had last touched on in Ezekiel 9:3. 
with the cloud, it tells you what had happened in the beginning, ${ }^{14}$ when it lifted off from the platform.

\section{Ezekiel 16:3}

Your origins: i.e., the place of your recognition, ${ }^{15}$ from the outset, and (your birth), the place of your birth, from the outset, were from the land of the Canaanites. Your father was from the land of the Amorites, and your mother was from the land of Heth. And it was not that they were actually of Amorite or Hittite extraction. Rather since below he will say your mother was a Hittite and your father an Amorite (v. 45), for her deeds were similar to the deeds of an Amorite or a Hittite, since her father and mother dwelled among them, he anticipated (that text and) said your father (was) an Amorite and your mother a Hittite. And this is the way of (Biblical) composition: it always begins with the crux of the matter, and with what it must complete. And see, he says, as it were, "You are in your deeds as if your father, who dwelled in the land of the Amorites (were) an Amorite like them, and your mother (were) a Hittite like them." But in any event, the crux of the matter he does not now elaborate to you, only their origins and sojourns in the land of the Amorite and Hittite at the beginning, in a land not theirs.

\section{Ezekiel 17:2-5}

Ezekiel 17:2: (O Man), propound a riddle and relate an allegory: (relate) another (allegory): perhaps the words will enter into their hearts, and they will relate (them) to their brothers in the Land (of Israel) so that they repent.

\section{Ezekiel 17:3}

(The great eagle) with the great wings and the long pinions with the full plumage and embroidery: winged creatures produce all of these things, making a shadow. And (it uses this imagery) since (below the text) will say and that (its branches should face him) and its roots should be under him (17:6). And this (text) refers to Nebuchadnezzar, as it will

${ }^{14}$ I.e., in Ezekiel 9:3.

15 As did Yosef Kara before him, Eliezer confuses the root of the Hebrew word for "origins," with the similarly-sounding for "recognition." 
make explicit below (v. 12): The embroidery (refers to) the splendor of (Nebuchadnezzar's) majesty of the world. The Lebanon, a place of cedar trees. So is the Land of Israel a place of mighty kings. The crown of the cedar: this is the central part of the body (of the tree), i.e., the king.

\section{Ezekiel 17:4}

Its topmost bough: the top of the top-most shoot, the highest among them - these are the false-gods of the land. He plucked: from his kingdom this is Jehoiachin, King of Judah. The Land of Canaan: that is to say, a place of traders, where cedars are not important there, rather in a place of kings and princes who build buildings and palaces. Even thus was Jehoiachin, who was not considered (important) in Babylon, in a foreign land.

\section{Ezekiel 17:5}

And he took from the seed of the land: from a fruit-bearing tree (he took) seed, (from a tree) that bears fruit with the seed in it on the land, ${ }^{16}$ which is a low tree - this is Zedekiah, (Jehoiachin's) uncle, who wasn't as worthy of the kingship as he. He set it like a willow beside abundant waters in which they sow seeds of trees (from which) to take and pluck (fruit). Beside abundant waters: in a place of willows and the flooding of waters, for abundant waters flood regularly around it, there shall set it.

\section{Ezekiel 18:3-4 ${ }^{17}$}

As the life of the father, so is it dear to me, the life of the son, nor did I favor (lit. "lift up my face") the father more than the son, but slow to anger am I for the sake of my name (see Isaiah 48:9) and for the sake of the city that I have chosen (see $1 \mathrm{Kgs} 11: 32$ ) - until now. But from now on I will be slow to anger no longer, and you will no longer recite such parables, but rather you will be to me as individuals: the life of (the one who) sins, alone shall he die, and to the extent that you dissent in my presence, you shall be punished. One may also say that they (those proverb-reciting Judeans) erred in what they (thought they) had seen, i.e., that the early ones had not been punished, whereas the later ones had been punished,

16 See Genesis 1:11.

${ }^{17}$ In this comment, Eliezer relates to the differing theologies posed by such Torah texts as Exodus 20:5 and Ezekiel's prophecy here. For a discussion, see Harris (2011), 83-84. 
and they were of the opinion that that is how the world runs. For in the days of Jeroboam son of Nebat they had sinned, ${ }^{18}$ and Hosea son of Elah and his generation had been punished $;{ }^{19}$ Manassah had sinned, ${ }^{20}$ and Jehoahaz, Jehoiakim and Jehoiachin his descendants had been punished; ${ }^{21}$ and even Josiah the righteous one had fallen by the sword. ${ }^{22}$ But this is not just! And he (Ezekiel) responded to them that they should no longer recite this parable, that (God) would no longer be slow to anger as he had been until then, but now forever would He punish them, from generation to generation, whenever they sinned.

\section{Ezekiel 20:24-26}

Because my judgments they did not do: This pertains to those who were coming to the Land. And the narrative obfuscates and afterwards makes it explicit: By this too your fathers affronted Me... (v. 27). This is its explanation: And therefore because my judgments did Israel never obey, Moreover, I gave them laws that were not good, as though to say, even with regard to the laws that I gave them they would not receive a reward and so there was not any goodness about them, even were they to have done them. And judgments through which they could not live since after their fetishes and the detestable things of their fathers did their heart $g o,{ }^{23}$ even their gift-offerings that they will give to me will be defiled before $\mathrm{Me}$, nor will these be considered desirable on their behalf, like the contextual-meaning ${ }^{24}$ (of the following verse): Whatever they offer there is defiled (Haggai 2:14); and like the contextual-meaning (of the following verse: To what purpose to Me is the multitude of your sacrifices? says the LORD (Isaiah $1: 11)$. When they set aside every first issue of the womb: This was then holy in and of itself, and was not their gift, For every first-born is Mine: [at the time that I smote every first-born] in the land of Egypt (Numbers 3:13)

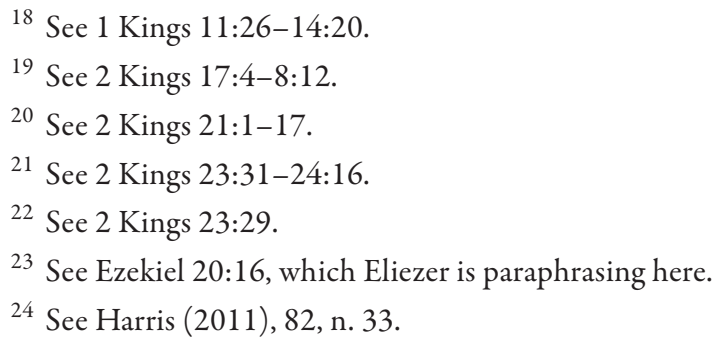


- nevertheless it is defiled in My eyes. What is the reason for this? In order that my knowledge and my will should render them desolate. ${ }^{25}$

\section{Ezekiel 29:1}

In the tenth year: (i.e.,) before the prophecy against Tyre. ${ }^{26}$ But on account of the punishment (inflicted against) the rest of the nations that reviled and opened wide their mouths against Jerusalem, (the redactor) joined/composed the prophecy against Tyre with them as well; since she (Tyre), too, reviled (Jerusalem) and rejoiced in her downfall, she was punished like them. ${ }^{27}$

\section{Ezekiel 29:21}

On that day: i.e., [the day on which] I will give Egypt into the hand of Nebuchadnezzar. I will endow with strength ${ }^{28}$ the House of Israel that is there (i.e., in Egypt), for I will not make a complete destruction of them, as I will with respect to Egypt. This is made explicit in Jeremiah in his "Prophecy concerning Egypt" (chapter 46): but as for you, do not fear, $O$ my servant Jacob, nor be dismayed, O Israel... for I shall make a complete destruction of all the nations where I have banished you, whereas of you will not make a destruction (Jeremiah 46:27-28). That is what is meant by "endowment with strength" (i.e., here in Ezekiel 29:21), that refugees who have taken shelter there will be able to return to their land and not be destroyed there (i.e., in the destruction of that land). And with respect to all of the prophecies concerning the downfall of the nations, you will not find Israel mentioned for safety - except with respect to Egypt, here (in

${ }^{25}$ Eliezer paraphrases the end of v. 26.

${ }^{26}$ See Ezekiel 26:1-28:19.

${ }^{27}$ Eliezer normally assumes that, unless there is specific evidence to the contrary, Scripture follows chronological order. However, when it explicitly does not, he seeks to find some logical reason (e.g., literary or thematic) that would justify a different arrangement. Since the redactor explicitly states that Ezekiel's prophecy in 29:1 came "in the tenth year," whereas the one beginning in Ezekiel 26 came "in the eleventh year," Eliezer must attempt to account for the anachrony. See also the following comment included here.

${ }^{28}$ Lit. "I will cause a horn to sprout," an ancient Hebrew idiom that generally promises deliverance. Because of the particular biblical context at hand, Eliezer will prefer to read the idiom differently than earlier biblical exegetes (cf. Rashi). See further. 
Ezekiel) and in Jeremiah. Therefore do I say that this "endowment with strength" ${ }^{29}$ is not here a general term for deliverance (as it is elsewhere in the Bible), as stated by our great rabbi, may his rest be one of honor. ${ }^{30}$ Rather, it is according to the words of Jeremiah, i.e., that [God] would not destroy them in the lands of their banishment. ${ }^{31}$ Moreover, [Rashi's] calculation [of the prophet's words] with respect to the time of Belshazzar (see Daniel 7) does not fit according to the plain sense ${ }^{32}$ [of Scripture]; indeed, the calculations of [the Babylonian Talmud in Tractate] Megilla (11b) are not done according to the plain sense. Furthermore, we have not found Ezekiel mentioned among those who returned from Babylonia. And furthermore, why did [the redactor] have to displace ${ }^{33}$ this verse until here? It would have been more proper for him to say it above, since it harkens back to at the end of forty years (Ezekiel 29:13). Nevertheless, the placement of the prophecy against Egypt that is here (vv. 17-20) is correct. For its beginning is in the tenth year (29:1), and after it he preceded the "prophecy of the twenty-seventh (year)" (29:17ff) to the two "prophecies of the eleventh (year)" (30:20ff and 31:1ff) and two "prophecies of

29 I.e., the specific employment of the idiom "sprouting of a horn" here in Ezekiel.

${ }^{30}$ Eliezer appears to reference Rashi here; however, in medieval transmission there is a significant overlap of the Ezekiel commentary of "Rashi" and that of "R. Yosef Kara," and no one to my mind has completely resolved this conundrum. Moreover, Rashi begins his commentary on this verse with the statement, "I have not heard nor have I found a (satisfactory) explanation of this verse, what (the mention of) 'endowment of Israel with strength' is doing here in (the prophecy of) Egypt's fall." That would indicate that he, himself, may not have supplied the actual exegesis to which Eliezer refers. In many variants, the continuation of Rashi's comment begins with the words "but I say"; these words may, in fact, emanate from either Rashi's secretary R. Shemaiah or another member of Rashi's intimate circle.

31 Thus, the "sprouting of a horn/endowment with strength" expression here and in Jeremiah is a promise more limited in scope than the phrase generally implies elsewhere in Scripture.

32 Eliezer employs the term peshat here, and again in the next sentence.

33 Eliezer employs two technical terms here, לשייר, le-shayyer ("to displace/leave over") and מוסב, musav (lit. "turns on," by which he means "harkens back to" or sometimes "corresponds to"). Although the first term is more specific to his own exegesis, most of the northern French rabbinic exegetes regularly employ the second; both terms are used to alert the reader to a variety of structural issues in biblical composition. 
the twelfth year" $(32: 1,17) \ldots$ These advancements ${ }^{34}$ (in the placement) of the "prophecy of the twenty-seventh (year)" were for a purpose; after it, (the redactor) is careful in his order: the early is presented early, and the later is presented later.

\section{Ezekiel 30:1}

The word of the Lord came to me: (The redactor) returns to complete the prophecy of the twenty-seventh (year), since he had already begun it. And since he had brought it above only en passant, as I have explained, he abbreviated it. And now he makes explicit how he (God) will deliver it (i.e., Egypt) into the hand of Nebuchadnezzar. ${ }^{35}$

\section{Ezekiel 32:16}

This is a dirge: That with which he begins (the composition), he (also) concludes. ${ }^{36}$

${ }^{34}$ Again, by the term "advancements," Eliezer addresses a significant contribution by his teacher, Rashbam, to the understanding of biblical narrative poetics. As I have mentioned above, Rashbam had considered prolepsis to be one of the distinctive features of biblical narrative, and he used the Hebrew verb $מ-7-p, q-d-m$, in the causative conjugation (biphil) to alert the attentive reader that the narrator or redactor had placed a certain verse/pericope or even entire biblical book earlier in the text than was otherwise necessary for a variety of reasons of narrative disclosure. In this example, Eliezer appears to resist understanding aspects of the prophetic narrative in Ezekiel 29 as completely proleptic in character, but rather tries to find a narrative rationale for the redactor's decisions that are more linear in character.

35 See Ezekiel 29:19.

${ }^{36}$ Eliezer takes into account both the beginning of the prophecy (after the superscription in 32:1), "O mortal, intone a dirge over Pharaoh king of Egypt" and the lament's conclusion in v. 16, "This is a dirge, and it shall be intoned; The women of the nations shall intone it, They shall intone it over Egypt." The literary device to which he calls our attention (here and in other verses, as well) is called inclusio; this occurs when a word or words found in the beginning of a literary unit are repeated at the end of the unit. Eliezer's pithy phrase is one of the earliest identifications of this device in the history of literature; see Harris (2009), 326; and Harris (1997), 202-7. 


\section{Ezekiel 42:3, 5-6 37}

Facing the twenty cubits, this phrase harkens back to opposite the vacant space $^{38}$ (Ezekiel 42:1)...and facing the pavement, harkens back to facing the structure (Ezekiel 42:1), as though to say, that (part) that was facing the pavement of the outer court, also faced the areas that were mentioned above ${ }^{39}$ towards the sides of the gates of the outer courtyard; areas facing areas. (The complex rose) ledge by ledge (in three tiers): ${ }^{40}$ The ledge of this one from before the ledge of the (next) one. In three (tiers): their higher ones, for that's where the ledges were, as it will make clear below. ${ }^{41}$ Now, with regard to the ledges (their construction and function in context $\left.{ }^{42}\right)$ - their context will explain them below, ${ }^{43}$ as much as the mind can discern. For with regard to a word that has no cognate, and which you can understand from its function in context, why cast your eyes to the ends of the earth!? ${ }^{44}$ Its context indicates its meaning. Behold, Scripture has informed you $^{45}$ the width of the rooms in the outer court and in the inner court, and the length that they had from east to west in the inner court,

${ }^{37}$ I incorporate elements of Eliezer's comments on these verses together, inasmuch as they function as an extended gloss on the difficult Hebrew word atik; throughout, I have adopted NJPS “ledge," particularly since it more or less comports with Eliezer's interpretation. See Walther Zimmerli, "Ezekiel 2: A Commentary on the Book of the Prophet Ezekiel, Chapters 25-48” (Hermeneia. James D. Martin, trans.; Philadelphia: Fortress Press, 1983), 382, note c.

38 So NJPS; RSV suggests "the temple yard."

39 I.e., the ones mentioned in Ezekiel 40:17-18.

${ }^{40}$ So NJPS. For a lucid explanation, see Zimmerli (1983), 398.

${ }^{41}$ I.e., in Ezekiel 42:5.

42 Again, the term of choice for Eliezer is שיטת עניינם, shittat inyanam, literally, "the mode of their matter." We have seen that the northern French rabbinic exegetes use the term shittah to express the modus of an aspect of biblical composition (that is, "how" a matter was expressed or functioned) whereas to express an understanding of sensus (the contextual sense, that is, "what" something meant), they employed several terms, among them peshat/peshuto, mashma' and 'inyan. Here, Eliezer has combined terms from each "category." As he makes clear, below, he found the form and function of these passages from Ezekiel nearly intractable, and eventually hit on a solution only while dreaming!
${ }^{43}$ In Ezekiel 42:5-6.
${ }^{44}$ I.e., don't be a fool; see Proverbs 17:26.
${ }^{45}$ In Ezekiel 42:2. 
one-hundred cubits. And now it will relate to you their lengths from east to west in the outer court. ${ }^{46}$ (As to the word) ledge, ${ }^{47}$ its context will instruct about it, ${ }^{48}$ as (Scripture) says, because ledges took away from them, thus you are forced to admit that it is a thing that enters ${ }^{49}$ into the depth of the building('s construction), and detracts (from its actual dimensions), and it rests upon it. There is also something about its meaning with respect to height and its upward removal from the ground, as in Ancient (Daniel 7:13); He moved on from there to the hill country (Genesis 12:8); and let not arrogance upwardly rise from your mouth (1 Samuel 2:3). ${ }^{50}$ So does (the context) of that is why it (the upper chamber) is withdrawn...from the ground. And all of its height slants and rises towards the entrance, and then diminishes... ${ }^{51}$ This explanation was hinted to me in a dream, for out of great distress with which I was distressed to discover the contex-

${ }^{46}$ I.e., in Ezekiel 42:4.

47 The remainder of this comment is found in the commentary on Ezekiel 42:5-6.

48 Phrases such as these abound among all of the northern French rabbinic exegetes, Eliezer among them. It is a formula that emphasizes the importance of context in determining meaning. See Harris (2009), 312-15.

49 This is Eliezer's en passant gloss of the Biblical Hebrew word meaning "consumes," that is, the ledges "eat away" at the dimensions of the building's depth by extending out from it.

50 The status of these verses as prooftexts for Eliezer is not as clear as he might have hoped. Thus, in Daniel, the Aramaic word for "ancient" is 'atiq, thus appearing to be related to the elusive term from Ezekiel (אתיק, atiq; one similar letter distinguishes them from each other, see the following footnote). However, the broader context of the verse from Daniel does "help" him, since in the vision Daniel relates, "As I looked on... One like a human being came with the clouds of heaven," thus causing Daniel to cast his eyes in an upward sweep. In Genesis, Abraham moved on (ויעתק, va-ye'etaq) to the hill country, likewise an upward movement. Finally, in Samuel, a literal translation of Hannah's prayer in 2:3 might be rendered, "Do not increase speech higher, higher/may it not escape, that high talk (עתיק, 'ataq), from your mouth”; thus, for Eliezer, each of these verses help him to establish the meaning of the difficult word. Again, see below.

51 At this point, as he had just done, Eliezer points to words in two additional biblical verses (Isaiah 19:10 and Job 33:24) in which the Hebrew letters $\aleph$, aleph, and y, 'ayin, may interchange in Biblical Hebrew. A perusal of northern French rabbinic commentaries on these verses indicates that both Eliezer and other exegetes make similar observations there. This insight helps him to explain the word אתיק, atiq, that has so troubled him in this extended passage from Ezekiel 42. By reading it as עתיק, 'atiq, instead, Eliezer gains support for his explanation that the word means "something removed from" or "extending outward" from something else. 
tual meaning (of the word), I nodded off with my book open before me. ${ }^{52}$ And I saw (in my dream) and, behold, a man gave into my hands a scroll to read. And at the top of the third column, it was written: the future "ledges" are extensions ${ }^{53}$ and olive trees. And I would explain that as: the future "ledges" that are written (in Ezekiel's account) of the future Temple are extensions and balconies of olive trees and pine trees. ${ }^{54}$ Also the words of our rabbis will be established, who said "(The wall around the Women's Courtyard) ${ }^{55}$ was originally smooth (with no extensions from it) but later a balcony was built around it." All of this I expounded in my dream.

${ }^{52}$ Literally, "I slumbered on the book."

${ }^{53}$ This is a word that Eliezer presumably gets from the Aramaic Targum.

${ }^{54}$ See Nehemiah 8:15.

55 Mishna Middot 2:5. The subject of this particular Mishna paragraph is the Woman's Courtyard, and it begins with the observations that "its area was one hundred and thirty five cubits by thirty five cubits. And there were four chambers in its four corners each forty cubits (in length) and they did not have a roof. And this is the way they will be in the future" (i.e., in the future "Third Temple," which is what the rabbinic Sages call Ezekiel's visionary, never-built Temple). 



\section{Bibliography}

Anderson, Francis I., and David Noel Freedman. Amos: A New Translation With Introduction and Commentary. New York: Doubleday, 1989.

Banitt, Menahem. Le Glossare De Bale: Introduction. Jerusalem: The Israel Academy of Science and Humanities, 1972.

- Le Glossare De Bale: Introduction, Corpus Glossariorum Biblicorum Hebraico-Gallicorum Medii Aevi, Tomus Primus. Jerusalem: The Israel Academy of Science and Humanities, 1972.

—. Le Glossare De Bale: Texte, Corpus Glossariorum Biblicorum Hebraico-Gallicorum Medii Aevi, Tomus Primus. Jerusalem: The Israel Academy of Science and Humanities, 1972.

_. "Exegesis or Metaphrasis." In Creative Biblical Exegesis: Christian and Jewish Hermeneutics Through the Centuries, edited by Benjamin Uffenheimer and Henning Graf Reventlow, 13-29. JSOT Supplement Series 59. Sheffield: Sheffield Academic Press, 1988.

—. Le Glossaire De Leipzig: Texte. Vol. 1, Corpus Glossariorum Biblicorum Hebraico-Gallicorum Medii Aevi, Tomus Secundus. Jerusalem: The Israel Academy of Sciences and Humanities, 1995.

Burrow, J. A. Medieval Writers and Their Work: Middle English Literature 11001500. Oxford; New York: Oxford University Press, 2008.

Cohen, Gerson. "Esau as Symbol in Early Medieval Thought." In Jewish Medieval and Renaissance Studies, edited by Alexander Altman, 19-48. Cambridge, MA: Harvard University Press, 1967.

Cohen, Menachem, ed.. Mikraot Gedolot "Haketer": A Revised and Augmented Scientific Edition of "Mikraot Gedolot" Based on the Aleppo Codex and Early Medieval Mss. Ramat Gan: Bar Ilan University, 1992-2013.

Cohen, Shaye J. D. "Does Rashi's Torah Commentary Respond to Christianity? A Comparison of Rashi With Rashbam and Bekhor Shor." In The Idea of Biblical Interpretation: Essays in Honor of James L. Kugel, edited by James L. Kugel, Hindy. Najman, and Judith H. Newman, 449-72. Leiden, Boston: Brill, 2004.

Dahan, Gilbert. "Les interpretations juives dans les commentaires du Pentateuque de Pierre le Chantre." In The Bible in the Medieval World: Essays in Memory of Beryl Smalley (Studies in Church History: Subsidia 4), edited by Katherine Walsh and Diana Wood, 131-56. Oxford: Basil Blackwell, 1985. 
Day, Gary. Literary Criticism: A New History. Edinburgh: Edinburgh University Press, 2008.

Driver, S. R. The Books of Joel and Amos. Cambridge: Cambridge University Press, 1907.

Elbogen, Ismar. Jewish Liturgy: A Comprehensive History. Translated by Raymond P. Scheindlin. Philadelphia: The Jewish Publication Society, 1993.

Everhart, Deborah. Commentary on the Book of Jonah: Haimo of Auxerre. Kalamazoo: Medieval Institute Publications, 1993.

Fudeman, Kirsten A. "The Old French Glosses in Joseph Kara's Isaiah Commentary (Ms Lutzki 778).” In Revue des études juives 165: 1-2; (2006): 147-77.

_. Vernacular Voices: Language and Identity in Medieval French Jewish Communities. Philadelphia: University of Pennsylvania Press, 2010.

Fishman, Talya. Becoming the People of the Talmud: Oral Torah as Written Tradition in Medieval Jewish Cultures. Philadelphia: University of Pennsylvania Press, 2011.

Frank, Daniel. Search Scripture Well: Karaite Exegetes and the Origins of the Jewish Bible Commentary in the Islamic East. Leiden, Boston: Brill, 2004.

Ginzberg, Louis. The Legends of the Jews. Translated by Henrietta Szold. Philadelphia: The Jewish Publication Society, 1913.

Glatt, David A. Chronological Displacement in Biblical and Related Literatures. Atlanta: Scholars Press, 1993.

Golb, Norman. The Jews in Medieval Normandy: A Social and Intellectual History. Cambridge: Cambridge University Press, 1998.

Gottlieb, Isaac. Order in the Bible: The Arrangement of the Torah in Rabbinic and Medieval Jewish Commentary [Hebrew]. Jerusalem, Ramat-Gan: Magnes Press; Bar Ilan University Press, 2009.

Greenberg, Moshe. "Jewish Conceptions of the Human Factor in Biblical Prophecy." In Justice and the Holy: Essays in Honor of Walter Harrelson, edited by Douglas A. Knight and Peter J. Paris, 145-62. Atlanta: Scholars Press, 1989.

Greenstein, Edward L. "Medieval Bible Commentaries." In Back to the Sources, edited by Barry Holtz, 212-59. New York: Summit Books, 1984.

—. "Wordplay, Hebrew." In The Anchor Bible Dictionary, edited by David Noel Freedman, VI: 968-71. New York: Doubleday, 1992.

—_. "Misquotation of Scripture in the Dead Sea Scrolls." In The Frank Talmage Memorial Volume I, edited by Barry Walfish, 71-83. Haifa: Haifa University Press, 1993.

Greimas, Algirdas Julien. Dictionnaire De L'ancien Français. Paris: Larousse, 1992. Grossman, Avraham. "The School of Literal Exegesis in Northern France." In Hebrew Bible/old Testament: The History of Its Interpretation. Volume I: From the Beginnings to the Middle Ages (Until 1300). Part 2: The Middle Ages, edited by Magne Saebo, 321-71. Gottingen: Vandenhoeck \& Ruprecht, 2000. 
Hailperin, Herman. Rashi and the Christian Scholars. Pittsburgh: University of Pittsburgh Press, 1963.

Harkins, Franklin T., and Frans Van Liere. Interpretations of Scripture: Theory. Turnhout: Brepols, 2012.

Harris, Robert A. "The Literary Hermeneutic of Rabbi Eliezer of Beaugency." PhD diss., Jewish Theological Seminary, 1997.

—. "Awareness of Biblical Redaction Among Rabbinic Exegetes of Northern France." [Hebrew, with English summary]. In Shnaton: An Annual for Biblical and Ancient Near Eastern Studies XIII (2000), 289-310.

- Discerning Parallelism: A Study in Northern French Medieval Jewish Biblical Exegesis. Providence, RI: Brown Judaic Studies, 2004.

—. "Structure and Composition in Isaiah 1-12: A Twelfth-Century Northern French Rabbinic Perspective." In "As Those Who Are Taught": The Interpretation of Isaiah From the LXX to the SBL, edited by Claire Mathews McGinnis and Patricia K. Tull, 171-87. Atlanta: Society of Biblical Literature, 2006.

—. "Contextual Reading: Rabbi Eliezer of Beaugency's Commentary on Jonah." In Bringing the Hidden to Light: Studies in Honor of Stephen A. Geller, edited by Diane Sharon and Kathryn Kravitz, 79-101. Winona Lake, IN: The Jewish Theological Seminary, in collaboration with Eisenbrauns, 2007.

—_. "Rashi's Introductions to His Biblical Commentaries." In Shai Le-Sara Japhet: Studies in the Bible, Its Exegesis and Its Language, edited by Moshe Bar-Asher, Dalit Rom-Shiloni, Emanuel Tov, and Nili Wayzana, 219-41 (English section). Jerusalem: The Bialik Institute, 2007.

__. "Rashi and the "Messianic" Psalms." In Birkat Shalom: Studies in the Bible, Ancient Near Eastern Literature, and Postbiblical Judaism Presented to Shalom M. Paul on the Occasion of His Seventieth Birthday, edited by Chaim Cohen, Victor Avigdor Hurowitz, Avi Hurvitz, Yochanan Muffs, Baruch J. Schwartz, and Jeffery H. Tigay, 845-62. Winona Lake, Indiana: Eisenbrauns, 2008.

—. "Twelfth-Century Biblical Exegetes and the Invention of Literature." In The Multiple Meaning of Scripture: The Role of Exegesis in Early-Christian and Medieval Culture, edited by Ienje van 't Spijker, 311-29. Leiden; Boston: Brill, 2009.

—. "The Reception of Ezekiel Among Twelfth-Century Northern French Rabbinic Exegetes." In After Ezekiel: Essays on the Reception of a Difficult Prophet, edited by Andrew Mein and Paul M. Joyce, 71-88. New York, London: T\&T Clark International, 2011.

- "Concepts of Scripture in the School of Rashi." In Jewish Concepts of Scripture: A Comparative Introduction, edited by Benjamin D. Sommer, 102-22. New York and London: New York University Press, 2012.

—_. "Jewish Biblical Exegesis in the Middle Ages: From Its Beginnings Through the Twelfth Century." In The New Cambridge History of the Bible, edited 
by Richard Marsden and Ann Matter, 596-615. Cambridge: Cambridge University Press, 2012.

Heschel, Abraham Joshua. The Prophets. New York: Harper \& Row, 1962.

Hindley, A., F. W. Langley, and B. J. Levy. Old French-English Dictionary. Cambridge: Cambridge University Press, 2000.

Kamin, Sarah. Rashi's Exegetical Categorization in Respect to the Distinction Between Peshat and Derash. Jerusalem: The Magnes Press, 1986.

Kamin, Sarah and Avrom Saltman. Secundum Salomonem: A 13th Century Latin Commentary on the Song of Songs. Ramat Gan: Bar-Ilan University Press, 1989.

Kanarfogel, Ephraim. "Trinitarian and Multiplicity Polemics in the Biblical Commentaries of Rashi, Rashbam and Bekhor Shor." Gesher 7 (1979): 15-37.

- The Intellectual History and Rabbinic Culture of Medieval Ashkenaz. Detroit: Wayne State University Press, 2013.

Lawee, Eric. "Introducing Scripture: The Accessus Ad Auctores in Hebrew Exegetical Literature From the Thirteenth Through the Fifteenth Centuries." In With Reverence for the Word: Medieval Scriptural Exegesis in Judaism, Christianity and Islam, edited by J. D. McAuliffe, B. D. Walfish, and J. W. Goering, 157-79. Oxford: Oxford University Press, 2003.

Lockshin, Martin I. Rabbi Samuel Ben Meir's Commentary on Genesis: An Annotated Translation. Lewiston, Lamperer, Queenston: The Edwin Mellen Press, 1989.

Maman, Aharon. "The Linguistic School: Judah Hayyuj, Jonah Ibn Janah, Moses Ibn Chiquitilla and Judah Ibn Balam." In Hebrew Bible/old Testament: The History of Its Interpretation. Vol. 1, From the Beginnings to the Middle Ages (Until 1300). Part 2: The Middle Ages, edited by Magne Saebo, 261-81. Gottingen: Vandenhoeck \& Ruprecht, 2000.

Marcus, David. “Nineveh's 'Three Days' Walk (Jonah 3:3): Another Interpretation." In On the Way to Nineveh: Studies in Honor of George M. Landis, edited by S. L. Cook and S. C. Winter, 42-53. Boston: American School of Oriental Research, 1999.

Mays, James Luther. Amos: A Commentary. Philadelphia: The Westminster Press, 1969.

Milgrom, Jacob. Leviticus 17-22: A New Translation With Introduction and Commentary. New York: Doubleday, 2000.

Minnis, A. J. Medieval Theory of Authorship: Scholastic Literary Attitudes in the Later Middle Ages. Philadelphia: University of Pennsylvania Press, 2010.

Muffs, Yochanan. "Who Will Stand in the Breach? A Study of Prophetic Intercession." In Love and Joy: Law, Language and Religion in Ancient Israel, 9-48. New York and Jerusalem: The Jewish Theological Seminary, 1992.

Neusner, Jacob, ed. Sifra: An Analytical Translation. Atlanta: Scholars Press, 1988.

Nevo, Yehoshafat. "Descriptions of Realia in the Commentaries of Rabbi Eliezer of Beaugency" [Hebrew]. Sinai 99:1-2 (1986), 1-5. 
Nutt, John W. Commentaries on the Latter Prophets By R. Eliezer of Beaugency: Isaiah [Hebrew, with English introduction]. London, Paris, and Frankfort: Joseph Baer and Co., 1879.

Paul, Shalom. Amos. Hermeneia - A Critical and Historical Commentary on the Bible. Minneapolis: Fortress Press, 1991.

Poznanski, Samuel. Commentary on Ezekiel and the Twelve Minor Prophets By Eliezer of Beaugency [Hebrew]. Warsaw: Mikize Nirdamim, 1913.

Saenz-Badillos, Angel, ed. Tesubot De Dunas Ben Labrat. Granada: Universidad de Granada, Universidad Pontificia de Salamanca, 1980.

—. ed. Menahem Ben Saruq: Mabberet (Granada: Universidad de Granada, Unversidad Pontificia de Salamanca, 1986.

- A History of the Hebrew Language. Translated by John Elwolde. Cambridge: Cambridge University Press, 1993.

Sarna, Nahum. "The Anticipatory Use of Information as a Literary Feature of the Genesis Narrative." In The Creation of Sacred Literature, edited by R. E. Friedman, 76-82. Los Angeles: University of California Press, 1981.

Sasson, Jack M. Jonah. Anchor Bible. New York: Doubleday and Company, Inc., 1990.

Sherwood, Yvonne. A Biblical Text and Its Afterlives: The Survival of Jonah in Western Culture. Cambridge: Cambridge University Press, 2000.

Signer, Michael. "Consolation and Confrontation: Jewish and Christian Interpretation of the Prophetic Books." In Scripture and Pluralism: Reading the Bible in the Religiously Plural Worlds of the Middle Ages and Renaissance, edited by Thomas J Heffernan and Thomas E Burman, 77-93. Leiden; Boston: Brill, 2005.

Silberman, Lou H. “Justice and Mercy of God.” In Encyclopedia Judaica VII, edited by Cecil Roth, 669-70. Jerusalem: Keter Publishing House, Ltd., 1971.

Simon, Uriel. "Ibn Ezra Between Medievalism and Modernism: The Case of Isaiah Xl-LXVI." Vetus Testamentum Supplements 36 (1983), 257-71.

—. Abraham Ibn Ezra's Two Commentaries on the Minor Prophets: An Annotated Critical Edition. Vol. 1, Hosea, Joel, Amos. [Hebrew]. Ramat Gan: Bar Ilan University Press, 1989.

—. The JPS Bible Commentary: Jonah. Philadelphia: The Jewish Publication Society, 1999.

Steiner, Richard C. Stockmen from Tekoa, Sycomores from Sheba: A Study of Amos' Occupations. Catholic Biblical Quarterly Monograph Series 36. Washington DC: Catholic Biblical Association of America, 2003.

Strack, Hermann Leberecht, and Günter Stemberger. Introduction to the Talmud and Midrash. Translated by Marcus Bockmuehl. Minneapolis: T \& T Clark; Fortress Press, 1996.

Taylor, Jerome. The Didascalicon of Hugh of St. Victor. New York: Columbia University Press, 1961.

Van Liere, Frans. Andrew of St. Victor: Commentary on Samuel and Kings: Introduction, Translation and Notes. Turnhout: Brepols, 2009. 
—. and Mark Zier. Andreas: Expositionem Svper Dvodecim Prophetas. Turnhout: Brepols, 2007.

Weiss, Meir. Scriptures in Their Own Light: Collected Essays [Hebrew]. Jerusalem: Bialik Institute, 1987.

Wolff, Hans Walter. Joel and Amos: A Commentary on the Books of the Prophets Joel and Amos. Philadelphia: Fortress Press, 1977.

Zimmerli, Walther. Ezekiel 2: A Commentary on the Book of the Prophet Ezekiel, Chapters 25-48. In Hermeneia. Translated by James D. Martin. Philadelphia: Fortress Press, 1983.

Zucker, Moshe. "Towards a Solution to the Problem of the Thirty-Two Rules and the 'Mishnah of Rabbi Eliezer." Proceedings of the American Academy for Jewish Research 23 (1954): Hebrew Section, 1-39. 


\section{Index}

The index does not include citations of Amos, Jonah, Isaiah, and Ezekiel from the commentaries on verses from those books.

\section{Bible}

Genesis 1:1, p. 84 (n. 18)

Genesis1:11, p. 100 (n. 16)

Genesis 12:8, p. 106

Genesis 15:16, p. 61 (n. 265)

Genesis 18:15, p. 62 (n. 272)

Genesis 18:26, p. 77 (n. 64)

Genesis 19:19, p. 27 (n. 61)

Genesis 22:16, p. 49

Genesis 24:19, p. 53 (n. 220)

Genesis 24: 22, p. 53 (n. 220)

Genesis 28:10-11, p. 84

Genesis 28:11-22, p. 84 (n. 19)

Genesis 30:37-43, p. 16 (n. 5)

Genesis 37:2, p. 2

Genesis 41:45, p. 88

Genesis 42:1-2, p. 57 (n. 243)

Genesis 48:16, p. 35

Genesis 48:16, p. 35 (n. 118)

Genesis 49:16, p. 2 (n. 2)

Exodus 3:8, p. 46 (n. 181)

Exodus 4:13, p. 65 (n. 4)

Exodus 4:13, p. 66 (n. 9)

Exodus 7:18, p. 28 (n. 73)

Exodus 12:1, p. 52 (n. 219)

Exodus 12:5, p. 77

Exodus 12:34, 39, p. 36 (n. 123)
Exodus 13:9, p. 60 (n. 258)

Exodus 14:13, p. 90

Exodus 16:29, p. 90

Exodus 16:33, p. 33

Exodus 20:2, p. 22 (n. 42)

Exodus 20:5, p. 100 (n. 17)

Exodus 20:23, p. 60 (n. 257)

Exodus 21:1, p. 12

Exodus 22:1, p. 59 (n. 252)

Exodus 24:5-9, p. 44 (n. 168)

Exodus 25:6, p. 47 (n. 187)

Exodus 25:35, p. 58 (n. 249)

Exodus 29:12, p. 30 (n. 86)

Exodus 30:23, p. 47

Exodus 30:23-25, p. 47 (n. 187)

Exodus 34:6, p. 65 (n. 1)

Exodus 37:19-21, p. 58 (n. 249)

Leviticus 1:2, p. 44 (n. 168)

Leviticus 2:11, p. 36 (n. 123)

Leviticus 7:13, p. 36 (n. 123)

Leviticus 9:8-21, p. 44 (n. 168)

Leviticus 10:3, p. 50

Leviticus 18:21, p. 44 (n. 169)

Leviticus 18:25, p. 61 (n. 260)

Leviticus 18:27-28, p. 61 (n. 265)

Leviticus 19:10, p. 47 
Leviticus 23:27, p. 93 (n. 70)

Leviticus 26:5, p. 63

Leviticus 26:19, p. 39 (n. 141)

Leviticus 26:30, p. 3 (n. 131)

Numbers 9:2, p. 44 (n. 168)

Numbers 9:4-5, p. 44 (n. 168)

Numbers 10:9, p. 44

Numbers 11:20, p. 38 (n. 133)

Numbers 12:8, p. 98

Numbers 13:16, p. 88

Numbers 13:16, p. 88 (n. 44)

Numbers 14:9, p. 52

Numbers 14:9, p. 52 (n. 216)

Numbers 21:21-35, p. 87 (n. 33)

Numbers 24:17, p. 45

Numbers 24:17, p. 45 (n. 173)

Numbers 27:17, p. 46 (n. 179)

Deuteronomy 1:28, p. 60

Deuteronomy 2:23, p. 61 (n. 262)

Deuteronomy 2:27, p. 93

Deuteronomy 2:27, p. 93 (n. 66)

Deuteronomy 8:17, p. 51 (n. 209)

Deuteronomy 9:5, p. 61 (n. 265)

Deuteronomy 10:17, p. 61 (n. 267)

Deuteronomy 11:21, p. 18 (n. 20)

Deuteronomy 11:23, p. 61 (n. 261)

Deuteronomy 13:2, p. 86 (n. 25)

Deuteronomy 15:8, p. 21 (n. 35)

Deuteronomy 15:8, p. 57 (n. 242)

Deuteronomy 16:1, p. 52 (n. 219)

Deuteronomy 22:8, pp. 23-24, (n. 45

Deuteronomy 22:27, p. 55 (n. 233)

Deuteronomy 28:1, p. 46

Deuteronomy 28:52, p. 29 (n. 81)

Deuteronomy 28:68, p. 18

Deuteronomy 29:18, p. 26 (n. 58)

Deuteronomy 29:18, p. 42 (n. 155)

Deuteronomy 29:18, p. 46 (n. 176)

Deuteronomy 29:21-27, p. 38 (n. 134)

Deuteronomy 29:27, p. 62 (n. 271)

Deuteronomy 31:19, p. 81 (n. 9)
Deuteronomy 31:30, p. 80

Deuteronomy 31:2, p. 46 (n. 179)

Deuteronomy 32, p. 81 (n. 8)

Deuteronomy 32:1, p. 79

Deuteronomy 32:20, p. 58 (n. 247)

Deuteronomy 33:17, p. 51 (n. 210)

Deuteronomy 33:29, p. 52 (n. 213)

Joshua 2:9, p. 44 (n. 167)

Joshua 6:5, p. 35

Judges 5:6, p. 22

Judges 9:51, p. 30 (n. 83)

Judges 13:5, p. 86 (n. 28)

Judges 13:23, p. 72 (n. 4)

Judges 14:6, p. 27 (n. 60)

Judges 18:25, p. 55 (n. 229)

1 Samuel 1:17, p. 74 (n. 45)

1 Samuel 2:1-10, p. 72

1 Samuel 2:3, p. 106

1 Samuel 6:9, p. 28 (n. 66)

1 Samuel 9:9, p. 16 (n. 7

1 Samuel 10:6, p. 27 (n. 60)

1Samuel 12:23, p. 46 (n. 180)

1 Samuel 14:4, p. 32 (n. 98)

2 Samuel 3:1, p. 46

2 Samuel 5:2, p. 62 (n. 276)

2 Samuel 8:15, p. 46 (n. 178)

2 Samuel 12:4, pp. 32-33 (n. 101)

2 Samuel 12:24, p. 88 (n. 40)

2 Samuel 12:25, p. 88

1 Kings 5:26, p. 19 (n. 24)

1 Kings 9:12-13, p. 19 (n. 24)

1 Kings 10:19-20, p. 60 (n. 257)

1 Kings 11:26-40, p. 54 (n. 228)

1 Kings 11:26-14:20, p. 101 (n. 18)

1 Kings $11: 32$, p. 100

1 Kings 12:20, p. 54 (n. 228)

1 Kings 19:4, p. 75 (n. 51)

1 Kings 21:15,25, p. 32 (n. 100) 
2 Kings 3:4, p. 15 (n. 3)

2 Kings 3:26-27, p. 20 (n. 28)

2 Kings 4:7, p. 93 (n. 69)

2 Kings 4:23, p. 56

2 Kings 4:23, p. 56 (n. 240)

2 Kings 6:8-18, p. 86 (n. 30)

2 Kings 6:16, p. 86

2 Kings 6:23, p. 18 (n. 20)

2 Kings 6:30, p. 89 (n. 50)

2 Kings 6:30, p. 90

2 Kings 9:36-37, p. 36 (n. 122)

2 Kings 13:7, p. 18 (n. 20)

2 Kings 14:23-29, p. 54 (n. 228)

2 Kings 15:29, p. 87 (n. 34)

2 Kings 16, p. 83 (n. 17)

2 Kings 16:9, p. 17 (n. 14)

2 Kings 16:9, p. 18

2 Kings 16:9, p. 18 (n. 22)

2 Kings 16:9, p. 87 (n. 32)

2 Kings 17:4-8:12, p. 101 (n. 19)

2 Kings 18:13, p. 91 (n. 59)

2 Kings 18:13, p. 91 (n. 61)

2 Kings 18:14-16, p. 91 (n. 60)

2 Kings 19:12-13, p. 18 (n. 20)

2 Kings 21:1-17, p. 101 (n. 20)

2 Kings $21: 13$, p. 54 (n. 226)

2 Kings 22:8, p. 95 (n. 3)

2 Kings 23:31-24:16, p. 101 (n. 21)

2 Kings 23:29, p. 101 (n. 22)

2 Kings 24:2, p. 18 (n. 20)

2 Kings 24:14, p. 62 (n. 273)

Isaiah $1: 1$, p. 79

Isaiah $1: 1$, p. 82

Isaiah $1: 2$, p. 79

Isaiah 1:18, p. 93 (n. 65)

Isaiah 1-12, p. 17 (n. 16)

Isaiah 5:1, p. 30 (n. 86)

Isaiah 5:8, p. 56 (n. 238)

Isaiah 5:19, p. 42

Isaiah 5:19, p. 42 (n. 159)

Isaiah 5:26-29, 83 (n. 14)

Isaiah $6: 1$, p. 80
Isaiah $6: 8$, p. 82

Isaiah $7: 1$, p. 80

Isaiah 7:2, p. 90 (n. 51)

Isaiah 7:4, p. 90

Isaiah 8:3-4, p. 86 (n. 24)

Isaiah $8: 10$, p. 86

Isaiah 9:3, p. 87

Isaiah $10: 27$, p. 87

Isaiah 14:28, p. 80

Isaiah 14:28, p. 91

Isaiah 16:10, p. 42

Isaiah 19:10, p. 106 (n. 51)

Isaiah 27:1, p. 60

Isaiah 27:1, p. 60 (n. 258)

Isaiah 28:17, p. 54 (n. 226)

Isaiah 32:9, p. 32 (n. 99)

Isaiah 34:1, p. 92

Isaiah 34:3, p. 38 (n. 133)

Isaiah 34:3, p. 50 (n. 204)

Isaiah $36: 1$, p. 80

Isaiah 36:1, p. 92

Isaiah $37: 3$, p. 86

Isaiah 37:38, p. 81 (n. 7)

Isaiah 38:6, p. 92

Isaiah 40:1, p. 80 (n. 4)

Isaiah 41:20, p. 51 (n. 211)

Isaiah 41:15, p. 18 (n. 19)

Isaiah 44:20, p. 32 (n. 97)

Isaiah 44:20, p. 89 (n. 47)

Isaiah 48:9, p. 100

Isaiah 51:6, p. 67

Isaiah 53:4, p. 89

Isaiah 57:20, p. 57 (n. 245)

Isaiah 58:13-14, p. 94 (n. 72)

Isaiah 66:23, p. 56 (n. 240)

Isaiah 66:23, p. 57

Jeremiah 2:18, p. 37 (n. 130)

Jeremiah 2:34, p. 59 (n. 252)

Jeremiah $4: 8$, p. 89

Jeremiah 4:29, p. 38

Jeremiah 5:12, p. 47

Jeremiah 5:27, p. 56 (n. 234) 
Jeremiah 7:25-26, p. 26 (n. 54)

Jeremiah 13:14, p. 61

Jeremiah 16:5, p. 48

Jeremiah 16:5, p. 48 (n. 192)

Jeremiah 16:16, p. 35

Jeremiah 17:15, p. 42

Jeremiah 20:7, p. 28 (n. 70)

Jeremiah 20:9, p. 28 (nn. 72-73)

Jeremiah 22:19, p. 35

Jeremiah 22:28, p. 67

Jeremiah 23:17, p. 26 (n. 58)

Jeremiah 32:35, p. 44 (n. 169)

Jeremiah 33:12, p. 62 (n. 275)

Jeremiah 46:27-28, p. 102

Jeremiah 48:45, p. 36 (n. 123)

Jeremiah 49:1, p. 19 (n. 26)

Jeremiah 50:14; p. 24 (n. 48)

Jeremiah 51:25, p. 23 (n. 43)

Jeremiah 51:46, p. 27 (n. 64)

Ezekiel 1:22, p. 97 (n. 11)

Ezekiel 9:3, p. 98

Ezekiel 9:3, p. 99 (n. 14)

Ezekiel 11:3, p. 34

Ezekiel 11:3, p. 34 (n. 108)

Ezekiel 11:7, p. 34

Ezekiel 11:11, p. 34

Ezekiel 20:9, p. 51 (n. 212)

Ezekiel 20:16, p. 101 (n. 23)

Ezekiel 21:15, p. 45

Ezekiel 21:15, p. 45 (n. 173)

Ezekiel 23:24, p. 34

Ezekiel 24:24, p. 96

Ezekiel 26:1-28:19, p. 102 (n. 26)

Ezekiel 30:6, p. 39 (n. 141)

Ezekiel 40:4, p. 95

Ezekiel 40:17-18, p. 105 (n. 39)

Ezekiel 46:1, p. 56 (n. 240)

Ezekiel 46:1, p. 57

Hosea 1:1, p. 86 (n. 26)

Hosea 1:2, p. 86
Amos 1:1, p. 82 (n. 13)

Amos 2:13, p. 24 (n. 45)

Amos 9:7, p. 87

Jonah 1:5, p. 49 (n. 197)

Jonah 1:13, p. 59

Micah 1:11, 14, p. 82

Nahum 3:17, p. 52 (n. 218)

Haggai 2:14, p. 101

Zechariah 2:9, p. 44 (n. 166)

Psalms 10:9, p. 22 (n. 38)

Psalms 11:2, p. 24 (n. 48)

Psalms 18:7-8, p. 16 (n. 10)

Psalms 20:8, p. 50

Psalms 25:8, p. 46 (n. 180)

Psalms 34:17, p. 62 (n. 270)

Psalms 35:13, p. 89

Psalms 55:4, p. 24

Psalms 55:4, p. 24 (n. 45)

Psalms 58:10, p. 35

Psalms 66:6, p. 41 (n. 149)

Psalms 66:11, p. 24

Psalms 66:11, p. 24 (n. 45)

Psalms 66:11, p. 24 (n. 46)

Psalms 72:6, p. 53

Psalms 76:4, p. 45

Psalms 77:4, p. 58 (n. 248)

Psalms 107:12, p. 38 (n. 136)

Psalms 107:30, p. 70

Psalms 119:174, p. 49 (n. 195)

Psalms 126:6, p. 63

Psalms 137:7-9, p. 19 (n. 25)

Psalms 141:7, p. 51 (n. 208)

Psalms 144:8,11, p. 32 (n. 97)

Psalms 144:8, 11, p. 89 (n. 47)

Psalms 146:4, p. 67

Joel 2:15, p. 27 (n. 65) 
Proverbs 14:4, p. 51

Proverbs 17:26, p. 105 (n. 44)

Proverbs 21:22, pp. 29-30

Proverbs 22:19, p. 95

Proverbs 30:18-19, p. 86 (n. 27)

Proverbs 30:19, p. 86

Job 9:9, p. 40

Job 2:11-13, p. 26 (n. 55)

Job 12:3, p. 57

Job 24:4, p. 22

Job 28:3, p. 39

Job 28:3, p. 39 (n. 140)

Job 33:24, p. 106 (n. 51)

Job 36:10, p. 28 (n. 67)

Job 38:31, p. 40

Song of Songs 7:5, p. 32

Song of Songs 8:6, p. 60 (n. 258)

Lamentations $1: 17$, p. 29

Lamentations 2:22, p. 26 (n. 56)

Lamentations 3:22, p. 73

Lamentations 3:22, p. 73 (n. 40)

Koheleth (Ecclesiastes) 1:6, p. 93

Koheleth (Ecclesiastes) 1:6, p. 93 (n. 66)

Koheleth (Ecclesiastes) 9:12,p. 27 (n.63)

Esther 3:7, p. 52 (n. 219)

Daniel 1:7, p. 88

Daniel 7:13, p. 106

Daniel 8:12, p. 40

Daniel 10:4, p. 96 (n. 7)

Nehemiah 3:38, p. 60

Nehemiah 8:9, p. 88

Nehemiah 8:15, p. 107 (n. 54)

Nehemiah 11:8, p. 52 (n. 218)

2 Chronicles 16:14, p. 49 (n. 197)

2 Chronicles 26:18-21, p. 80 (n. 3)

2 Chronicles $35: 13$, p. 33 (n. 107)

\section{New Testament}

Matthew 12:40, p. 71 (n. 32)

\section{Versions}

Aramaic Targum, pp. 8, 20 (n. 31), 30 (n. 86), 40 (n. 148), 41 (n. 153), 59 (n. 255), 77 (n. 59), 80, 80 (n. 3), 95

Latin Vulgate, p. 45 (n. 171)

\section{Rabbinic Sources}

Mishnah

Baba Metziah 2:11, viii

Middot 2:5, p. 107 (n. 55)

\section{Babylonian Talmud}

Gittin 90a, p. 62 (n. 272)

Hagigah 4b, p. 42 (n. 156)

Ketubot 55b; Gittin 9a, p. 48 (n. 193)

Ketubot 69a, p. 48 (n. 192)

Megillah $11 \mathrm{~b}$

Moed Qatan 28b, p. 48 (n. 192)

Rosh Hashanah 3a, p. 62 (n. 272)

Sanhedrin 42a, p. 58 (n. 246)

Sanhedrin 89a, p. 25 (n. 53)

Shabbat 13b, p. 95 (n. 2)

Sotah 16a, p. 12

Yebamot 48b, p. 23 (n. 43)

\section{Midrash}

Bereshit (Genesis) Rabba 12:15, p. 54 (n. 227)

Bereshit (Genesis) Rabbah (23:7), p. 40 (n. 147)

Mishnat R. Eliezer ("Thirty-two Rules of R. Jose Ha-Galili”) , p. 34 (n. 91)

Pirke De R. Eliezer 9, p. 65 (n. 5) 
Sifra (on Leviticus), Introduction (“Thirteen Rules of R. Ishmael”), p. 34 (n. 91) Sifrei Devarim (on Deuteronomy), p. 18 (n. 20)

\section{Medieval Exegetes}

R. Abraham ibn Ezra, pp. 40 (n. 145), 43 (n. 165), 44 (n. 168), 56 (n. 237)

Andrew of St. Victor, pp. 13, 69 (n. 22), 69 (n. 24)

Dunash ibn Labrat, p. 47 (n. 186)

Haimo of Auxerre, pp. 6 (n. 9), 71 (n. 32)

Hugh of St. Victor, pp. 1, 2 (n. 2), 11-12

Menahem ibn Saruk, pp. 23 (n. 44), 24 (n. 45), 47 (n. 186)

Nicholas de Lyra, p. 10, (n. 16)

Radak (R. David Kimhi), pp. 38 (n. 132), 39 (n. 143), 50 (n. 195), 56 (n. 235), 56 (n. 237)

Rashbam (R. Samuel ben Meir), pp. 1, 2 (n. 2), 4, 7, 11-13, 28 (n. 73), 31 (n. 93), 60 (n. 258), 81 (n. 7), 84 (n. 18), 88 (n. 44), 92 (nn. 63-64), 104 (n. 34)

Rashi (R. Solomon ben Isaac), pp. 2 (n. 3), 3, 7, 10, (n. 16), 19 (n. 26), 20 (nn. 31-32), 22 (n 39), 32 (n. 99), 36 (n. 123), 39 (n. 143), 41 (n. 153), 42 (n. 159), 44 (n. 168), 45 (n. 171), 47 (n. 186), 51 (n. 206), 53 (n. 220), 56 (n. 237), 59 (n. 255), 62 (n. 272), 74 (n. 45), 77 (n. 59), 83 (n. 16), 86 (n. 24), 87 (n. 38), 96 (n. 8), 102 (n. 28), 103 (n. 30)

R. Jonah ibn Janah, p. 33 (n. 107)

R. Judah ibn Balaam, p. 33 (n. 107)

R. Shemaiah, p. 103 (n. 30)

R. Yosef Bekhor Shor, pp. 7, 34 (n. 111)

R. Yosef Kara, pp. 7, 19 (n. 26), 20 (n. 31), 41 (n. 153), 47 (n. 186), 53 (n. 222), 56 (n. 235), 56 (n. 237), 74 (n. 45), 86 (n. 24), 93 (n. 65), 97 (n. 9), 99 (n. 15), 103 (n. 30)

\section{Old French}

Baleine ["whale"], Jonah 2:1, p. 71

Desedsiront [i.e., "disdain”], Amos 6:8, p. 49

Enformement ["formation"], Amos 5:26, p. 45

Estendiléz ["they stretched themselves out"], Amos 6:4, p. 47

Par de qui offaire? ["On account of whose affair"], Jonah 1:7, p. 68

Piliers ["pillar"], Amos 9:1, p. 58

Refraint ["refrain"], Amos 6:5, p. 47

Rente [“a payment"], Amos 5:11, p. 41

Retenant [“restrain”], Amos 2:13, p. 23

\section{Latin (?)}

Anprologus ["of (or concerning) the beginning"], Introduction to Isaiah, p. 79 


\section{TEAMS}

\section{COMMENTARY SERIES}

Haimo of Auxerre, Commentary on the Book of Jonah, translated with an introduction and notes by Deborah Everhart (1993)

Medieval Exegesis in Translation: Commentaries on the Book of Ruth, translated with an introduction and notes by Lesley Smith (1996)

Nicholas of Lyra's Apocalypse Commentary, translated with an introduction and notes by Philip D. W. Krey (1997)

Rabbi Ezra Ben Solomon of Gerona, Commentary on the Song of Songs and Other Kabbalistic Commentaries, selected, translated, and annotated by Seth Brody (1999)

Second Thessalonians: Two Early Medieval Apocalyptic Commentaries, introduced and translated by Steven R. Cartwright and Kevin L. Hughes (2001)

John Wyclif, On the Truth of Holy Scripture, translated with an introduction and notes by Ian Christopher Levy (2001)

The "Glossa Ordinaria" on the Song of Songs, translated with an introduction and notes by Mary Dove (2004)

The Seven Seals of the Apocalypse: Medieval Texts in Translation, translated with an introduction and notes by Francis X. Gumerlock (2009)

The Glossa Ordinaria on Romans, translated with an introduction and notes by Michael Scott Woodward (2011)

Nicholas of Lyra, Literal Commentary of Galations, edited and translated by Edward Arthur Naumann (2015)

Early Latin Commentaries on the Apocalypse, edited by Francis X. Gumerlock (2016) 
Typeset in Garamond Premier Pro

Medieval Institute Publications

College of Arts and Sciences

Western Michigan University

1903 W. Michigan Avenue

Kalamazoo, MI 49008-5432

http://wmich.edu/medievalpublications

WESTERN MICHIGAN UNIVERSITY 